\title{
ОСОБЕННОСТИ ДИНАМИКИ И КОМПОНЕНТЫ СНИЖЕНИЯ СМЕРТНОСТИ В МОСКВЕ В 1989-2017 ГГ.
}

\author{
ЕЛЕНА ПАПАНОВА, ВЛАДИМИР ШКОЛЬНИКОВ, СЕРГЕЙ ТИМОНИН
}

\begin{abstract}
Москва - регион с самой высокой ожидаемой продолжительностью жизни в России. Это крупнейший город страны с высокими доходами, особой структурой населения, высокой концентрацией всех ресурсов, в том числе в сфере здравоохранения, которому уделяется особое внимание на уровне городских властей. Отдельные этапы изменения продолжительности жизни в Москве уникальны по сравнению с большинством других регионов России. Разница в продолжительности жизни между Москвой и Россией в период с серединь 1990-х до середины 2000х годов была обусловлена главным образом более низкой смертностью населения в средних возрастах. Впоследствии главный акцент смещается на смертность пожилого населения. При положительной динамике показателей смертности в целом уровень и динамика смертности в отдельных возрастных группах в Москве выглядят неправдоподобно. Качество данных может оказывать заметное влияние на достоверность демографических показателей и требует отдельного внимания при анализе продолжительности жизни. В частности, численность пожилого населения Москвы может быть завышена, что влияет на показатели смертности в старших возрастах. Особенности смертности по причинам смерти в Москве в целом соответствуют среднероссийским тенденциям, однако наблюдается более быстрое снижение смертности от новообразований, а также более реалистичные возрастные коэффициенты смертности в стариих возрастных групnах.
\end{abstract}

Ключевые слова: смертность, продолжительность жизни, пожилой возраст, трудоспособньй возраст, качество статистических данных, причины смерти, Москва.

\section{ВВЕДЕНИЕ}

Успехи Москвы в увеличении ожидаемой продолжительности жизни неоднократно привлекали внимание исследователей [Андреев, Кваша, Харькова 2006, 2016; Zemlyanova, Lopakov, Ivanova 2017]. Москва наряду с другими глобальными городами как в развитых (Лондон, Нью-Йорк, Париж), так и в развивающихся странах (Сан-Паулу, Шанхай) [Gusmano et al. 2015, 2016; Preston, Elo 2014] вносит огромный вклад в экономику всей страны и характеризуется более высоким уровнем валового внутреннего продукта на душу населения [Андреев, Школьников 2018]. Наряду с высокими темпами экономического роста, Москву с другими глобальными городами объединяет и высокая доля мигрантов, которые могут отчасти определять более низкий уровень смертности в таких городах [Preston, Elo 2014]. ЕЛЕНА КОНСТАНТИНОВНА ПАПАНОВА (epapanova@hse.ru), НАЦИОНАЛЬНЫЙ ИССЛЕДОВАТЕЛЬСКИЙ
УНИВЕРСИТЕТ «ВЫСШАЯ ШКОЛА ЭКОНОМИКИ», РОССИЯ.

ВЛАДИМИР МИХАЙЛОВИЧ ШКОЛЬНИКОВ (vmshkolnikov@hse.ru), НАЦИОНАЛЬНЫЙ ИССЛЕДОВАТЕЛЬСКИЙ УНИВЕРСИТЕТ «ВЫСШАЯ ШКОЛА ЭКОНОМИКИ», РОССИЯ; ИНСТИТУТ ДЕМОГРАФИЧЕСКИХ ИССЛЕДОВАНИЙ ОБЩЕСТВА МАКСА ПЛАНКА, ГЕРМАНИЯ.

СЕРГЕЙ АНДРЕЕВИч ТИМОНИН (stimonin@hse.ru), НАЦИОНАЛЬНЫЙ ИССЛЕДОВАТЕЛЬСКИЙ УНИВЕРСИТЕТ «ВЫСШАЯ ШКОЛА ЭКОНОМИКИ», РОсСия.

ИССЛЕДОВАНИЕ ФИНАНСИРОВАЛОСЬ В РАМКАХ ПРОГРАММЫ ГОСУДАРСТВЕННОЙ ПОДДЕРЖКИ ВЕДУЩИХ УНИВЕРСИТЕТОВ РОССИЙСКОЙ ФЕДЕРАЦИИ « $5-100 »$.

СТАТЬЯ ПОСТУПИЛА В РЕДАКЦИЮ В ОКТЯБРЕ 2018 Г. 
Все это создает условия для опережающего роста ожидаемой продолжительности жизни в Москве по сравнению с Россией. Действительно, с конца 1990-х годов динамика ожидаемой продолжительности жизни в Москве имела совершенно иной характер по сравнению с подавляющим большинством других регионов России, а к 2017 г. разрыв в ожидаемой продолжительности жизни между столицей и остальной частью страны составил более 7 лет для мужчин и почти 4 года для женщин. Вместе тем сравнение Москвы с развитыми странами показывает, что при существующих показателях социальноэкономического развития продолжительность жизни в столице могла бы быть заметно выше [Андреев, Школьников 2018].

Преимущество Москвы по уровню продолжительности жизни по сравнению с остальной Россией отмечалось задолго до периода социально-экономических кризисов и изменений. В работе Валлена, Андреева и соавторов [Vallin et al. 2005] был проведен анализ данных о смертности по регионам и причинам смерти в годы переписей населения с 1970 по 1994 г. Наряду с низким межрегиональным неравенством на территории России, в 1970 г. в Москве, а также на юге европейской России, отмечалась более низкая смертность по сравнению со среднероссийским значением. В результате роста смертности к 1979 г. преимущество Москвы, как и ряда других областей европейской России, было утрачено. К 1989 г. на фоне антиалкогольной кампании преимущество Москвы восстановилось, однако отмечается также и то, что прирост продолжительности жизни в период 19851987 гг. был небольшим, и гораздо большим было снижение ожидаемой продолжительности жизни (ОПЖ) к 1994 г. [Shkolnikov et al. 1998a; Vallin et al. 2005]. Таким образом, снижение ОПЖ в Москве, как и в других благополучных областях, было более значительным, чем в регионах с худшим положением [Shkolnikov, Cornia 2000; Vallin et al. 2005]. Отмечается, что в 1990-х годах преимущество Москвы исчезло за счет резкого роста смертности от внешних причин, что могло быть связано с ростом смертности среди мигрантов, число которых, вероятно, выросло из-за увеличения разрыва в доходах между Москвой и другими регионами [Shkolnikov, Cornia 2000], при этом большая доля умерших от внешних причин приходится на население с низким образованием и работников физического труда [Shkolnikov et al. 1998a]. Что касается причин смерти в целом, то в 19691970 гг. Москва по паттерну смертности значительно не отличалась от среднероссийской картины и характеризовалась несколько более высокой смертностью от инфекционных заболеваний и болезней сердца (за исключением ишемической болезни и атеросклероза). К 1978-1979 гг. Москва, наряду с Санкт-Петербургом, характеризовалась уже совершенно иными особенностями по сравнению с Россией в целом и с другими регионами: более низкой смертностью от внешних причин, болезней органов дыхания и инфекционных заболеваний, более высокой смертностью от рака, ишемической болезни сердца (за исключением кардиосклероза) и особенно от прочих заболеваний, что вероятнее всего связано с качеством установления причины смерти [Vallin et al. 2005]. В целом такая картина сохранилась до 1988-1989 гг., за исключением перераспределения разницы с Россией внутри класса болезней системы кровообращения, связанным, опять же, с изменением практики кодирования. В 1993-1994 гг. для Москвы была характерна несколько более низкая смертность от внешних причин и цереброваскулярных заболеваний, наряду с заметно более высокой смертностью с не установленной причиной смерти и от атеросклеротического кардиосклероза [Vallin et al. 2005]. 
После 1994 г. в качестве главного отличия динамики смертности в Москве, по сравнению с Россией в целом, исследователи отмечают отсутствие выраженного роста смертности и более раннее начало ее устойчивого снижения [Андреев, Кваша, Харькова 2016]. В отношении более позднего периода прежде всего отмечается заметное лидерство Москвы по сравнению с другими регионами России.

Вместе с тем в работе [Андреев, Кваша, Харькова 2016] было показано, что несмотря на то, что уровень смертности в Москве заметно ниже, чем в других регионах и городах России, по сравнению с зарубежными мегаполисами смертность в Москве остается более высокой за счет отставания Москвы в начале 1990-х годов. В период с 1990-х годов темпы снижения смертности от всех причин и от некоторых классов причин смерти в Москве были выше, чем во многих зарубежных мегаполисах, что во многом объясняется более высоким начальным уровнем смертности. Отставание от зарубежных мегаполисов при этом сократилось ненамного, а основную часть отставания определяют болезни системы кровообращения и внешние причины смерти.

Особую роль, с точки зрения оценки уровня смертности в Москве, имеет качество данных. Разрыв в продолжительности жизни между Москвой и другими регионами объясняется более благополучными социально-экономическими характеристиками Москвы, более высокой долей населения с высшим образованием, совершенствующейся системой медицинской помощи. Вместе с тем быстрое увеличение различий между Москвой и остальной страной вызывает некоторые сомнения относительно правдоподобности темпов снижения смертности в Москве, а динамика отдельных показателей смертности подтверждает предположение о некотором завышении продолжительности жизни в Москве. Быстрые темпы увеличения разницы в смертности от новообразований (как от причины смерти, существенно менее подверженной влиянию социально-экономических кризисов и прочих потрясений, а значит и изменяющейся более стабильно) в трудоспособном возрасте избирательно среди мужчин указывают на возможное занижение смертности в данной половозрастной группе в начале 2000-х годов [Андреев, Кваша, Харькова 2006]. Скорректированные на возможное занижение смертности оценки авторов показывают существенно более низкие значения ОПЖ для мужчин, при этом преимущество Москвы по сравнению с другими регионами по-прежнему сохраняется [Андреев, Кваша, Харькова 2006].

В настоящее время фокус внимания исследователей смещается на пожилое население Москвы. Так, было показано, что рост межрегионального неравенства в смертности среди регионов России обусловлен исключительно более низкой смертностью пожилого населения в Москве и Санкт-Петербурге [Timonin et al. 2017]. Сопоставление же уровня продолжительности жизни в пожилом возрасте со смертностью в более ранних возрастах и со смертностью в пожилом возрасте в других странах показывает неправдоподобно высокую продолжительность жизни мужчин в Москве в пожилом возрасте [Папанова и др. 2017]. На основе этих соотношений приводится скорректированная оценка ОПЖ, которая снижает расхождения между Москвой и другими регионами, но также показывает преимущество Москвы. 
В данной работе проведен детальный анализ смертности в Москве. Целью работы является выявление особенностей смертности населения Москвы и компонент, определяющих эти особенности и снижение смертности в целом, как и опережение России по уровню продолжительности жизни. Будет показано, каким образом к середине 2010-х годов столица России достигла столь высокого уровня продолжительности жизни и значительно оторвалась от остальной России по этому показателю. Мы рассмотрим особенности изменения смертности в Москве по возрасту и основным группам причин смерти, отличия от среднероссийских показателей в отношении динамики смертности, ее уровня и структуры. Особое внимание будет уделено качеству данных о смертности и численности населения и его возможному влиянию на изучаемые показатели. Мы покажем, что часть прироста ожидаемой продолжительности жизни в Москве может являться следствием переоценки численности отдельных возрастных групп населения столицы [Папанова и др. 2017].

\section{ДАННЫЕ И МЕТОДЫ}

Нами были использованы данные Федеральной службы государственной статистики (Росстат) о распределении умерших и населения по полу, однолетним возрастам (до возраста 100+), данные о причинах смерти (в соответствии с их краткой номенклатурой) с распределением населения по полу, пятилетним возрастным группам, и рассчитанные на их основе коэффициенты смертности, представленные в Российской базе данных по рождаемости и смертности [ЦДИ РЭШ 2018]. Данные по России в целом доступны за 19592017 гг., по Москве и другим регионам Российской Федерации - за 1969-1970, 1978-1979 и 1989-2017 гг. Дополнительно для Москвы были использованы данные Управления ЗАГС города Москвы о зарегистрированных в Москве смертях по году рождения умерших, в том числе для умерших в возрасте старше 100 лет, для которых информация о точном возрасте/годе рождения не собирается Росстатом.

Для международных сравнений мы использовали также возрастные коэффициенты смертности и показатели полных таблиц смертности для некоторых европейских стран из Базы данных по смертности человека (Human Mortality Database) [University of California... 2018], которая является наиболее авторитетным источником точных данных о смертности, сопоставимых по годам и странам. Данные для европейских стран по причинам смерти были получены из базы данных по смертности ВO3 WHO Mortality Database [WHO 2018].

Мы определяем вклад изменений в смертности по возрастным группам и причинам смерти в изменения и разницу в ожидаемой продолжительности жизни с помощью метода декомпозиции [Андреев 1982; Andreev, Shkolnikov, Begun 2002]. Данные по причинам смерти сравнивались с помощью стандартизованных коэффициентов смертности, рассчитанных по методу прямой стандартизации с использованием европейского стандарта возрастной структуры населения 1976 г. Таким образом, полученные нами численные значения стандартизованных коэффициентов смертности сопоставимы с данными базы данных Health for All (HFA-DB) Европейского бюро Всемирной организации здравоохранения [WHO Regional Office... 2018]. 
Сравнение Москвы, России и других стран/регионов производится для всего населения. Вместе с тем в Москве представлено преимущественно городское население. С этой точки зрения целесообразным могло быть сравнение Москвы с городскими территориями России и других стран. Однако в странах Европы в целом не наблюдается отчетливой закономерности превышения ОПЖ городского населения над ОПЖ всего населения [Koster et al. 2017]. В некоторых странах городское население показывает лучшие результаты по сравнению с остальной страной, в других странах общее состояние здоровья было хуже среди горожан. В среднем разница между городским населением и населением в целом в странах Европы не так велика и составляет 1-2\% [Koster et al. 2017]. В связи с этим, а также с большей доступностью данных для стран в целом сравнение Москвы с населением страны в целом в контексте решения поставленных задач представляется оправданным.

\section{РЕЗУЛЬТАТЫ И ОБСУЖДЕНИЕ}

\section{Динамика ожидаемой продолжительности жизни}

\section{Продолжительность жизни при рождении}

Для динамики ожидаемой продолжительности жизни (ОПЖ) в Москве характерны те же особенности, что и для России в целом. Однако на отдельных этапах рассматриваемого периода изменения ОПЖ в Москве имели отличия в отношении их темпов и даже направления. В результате разрыв в продолжительности жизни между Москвой и остальной Россией существенно вырос.

В период до подъема смертности в середине 1990-х годов уровень ОПЖ в Москве среди мужчин был несколько выше, чем в России. В 1969-1970 гг. эта разница составила 2,3 года по сравнению с остальной Россией, среди женщин отличия составляли менее полугода (рисунок 1). Динамика показателя в Москве в эти годы вероятнее всего совпадала со среднероссийскими тенденциями, так как расхождения почти не изменились за 1969 1979 гг. и составили 2,5 года среди мужчин и 0,3 года среди женщин (таблица 1 Приложения).

В 1989-1991 гг., когда в России уже началось снижение продолжительности жизни, в Москве показатель почти не изменялся, а падение началось несколько позже - с 1992 г. Это падение было в Москве особенно значительным: за 1993 г. продолжительность жизни мужчин при рождении упала на 4 года по сравнению с 1992 г. (в России без Москвы - на 3 года). Всего за 1992-1994 гг. мужчины в Москве потеряли 7,3 года ОПЖ (в России без Москвы - 5,9 года). Среди женщин потери ОПЖ в Москве были меньше, чем в России (2,7 и 3,2 года соответственно).

За счет резкого падения ОПЖ разница в показателе между Москвой и Россией к началу 1990-х годов и вплоть до 1995 г. сократилась и составляла 0,9-1,6 года среди мужчин, среди женщин ОПЖ при рождении в 1989-1991 гг. оказалась даже немного ниже, чем в России в целом. Но уже в 1995-1996 гг. темпы прироста ОПЖ при рождении в Москве существенно опередили таковые в России. Продолжительность жизни в 1996 г. в России 
увеличилась на 1,4 года у мужчин и на 0,7 года у женщин, тогда как в Москве прирост составил 3,4 и 1,7 года соответственно, а разница между Москвой и Россией достигла 2,9 года у мужчин и 1,4 года у женщин. В 1997 г. высокие темпы прироста показателя в Москве сохранились, а разница между Москвой и Россией увеличилась до 3,9 года у мужчин и 1,6 года у женщин (таблица 1). К 1997-1998 гг. продолжительность жизни в Москве, в отличие от России, достигла значений, наблюдавшихся до подъема смертности.

Очередной рост смертности в 1999 г. наблюдался в большинстве регионов России, но не был характерен для Москвы. Наряду с падением продолжительности жизни в России до 58,9 года среди мужчин к 2001 г., в Москве продолжительность жизни почти не изменилась. С 2002 г. в Москве отмечается рост продолжительности жизни, начавшийся в России несколькими годами позже. С 2005 г. снижение смертности в Москве и в России происходило схожими темпами.

Интересно отметить, что в рассматриваемый период уровень и динамика продолжительности жизни в Москве во многом совпадали с тенденциями, наблюдавшимися в Эстонии. В частности, в Эстонии также не было падения продолжительности жизни в 1999 г., несмотря на то, что в предыдущий период тенденции изменения ОПЖ в России и Эстонии совпадали. Это особенно заметно среди мужчин: с 1998 г. показатели ОПЖ при рождении для мужчин в Москве и Эстонии находятся на одном уровне.

\section{мужчины}

85

80

75

70

65

60

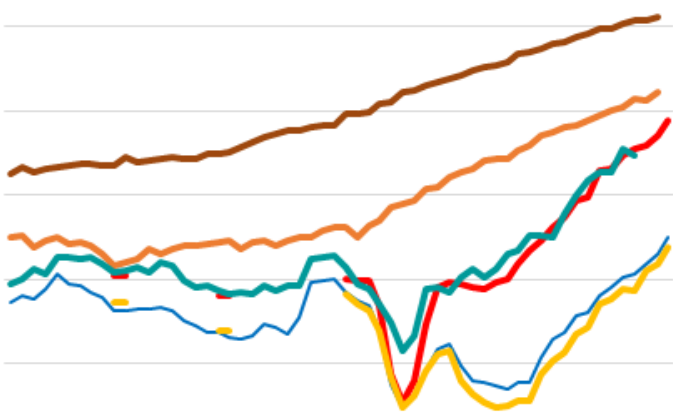

55

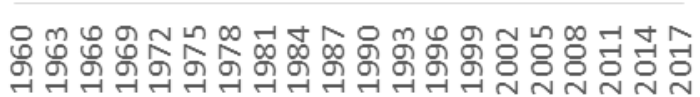

85

80

75

70

65

60

55

женщины

\section{(n)}

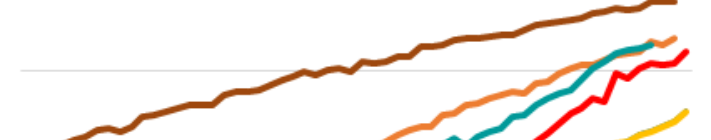

(
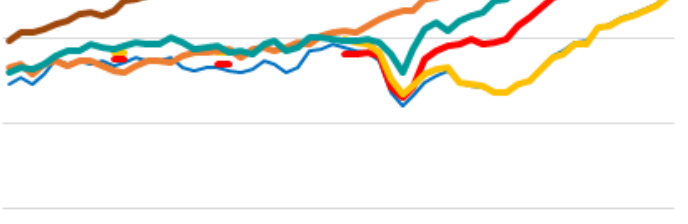

.

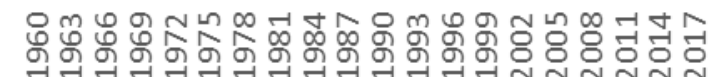

— Россия - Москва —ФО без Москвы

— Чехия —Эстония —Швеция

\section{Рисунок 1. Ожидаемая продолжительность жизни при рождении в Москве, России и некоторых странах, 1960-2017, лет}

Рост продолжительности жизни в Москве в 2005-2017 гг. в целом был равномерным, за исключением 2010-2012 гг. В 2010 г. вследствие жары смертность повысилась [Ревич 2011; Shaposhnikov et al. 2014], что было особенно заметно среди женщин. Подъем смертности, спровоцированный жарой, затронул главным образом население с высоким риском наступления смерти. Вследствие этого группа населения под риском наступления 
смерти в 2011 г. существенно сократилась, что привело к резкому росту продолжительности жизни. В 2012 г. показатель вернулся на «ожидаемый» уровень, несколько снизившись по сравнению с 2011 г.

Таблица 1. Прирост ожидаемой продолжительности жизни при рождении в Москве и России (без Москвы), 1989-2017, лет

\begin{tabular}{l|c|c|c|c}
\hline \multirow{2}{*}{ Годы } & \multicolumn{2}{|c|}{ Мужчины } & \multicolumn{2}{c}{ Женщины } \\
\cline { 2 - 5 } & Россия без Москвы & Москва & Россия без Москвы & Москва \\
\hline $1989-1991$ & $-0,83$ & $-0,11$ & $-0,29$ & $+0,03$ \\
$1992-1994$ & $-5,93$ & $-7,28$ & $-3,20$ & $-2,67$ \\
$1995-1998$ & $+3,58$ & $+7,16$ & $+1,99$ & $+3,05$ \\
$1999-2001$ & $-2,46$ & $-0,40$ & $-1,06$ & $+0,18$ \\
$2002-2005$ & $-0,14$ & $+2,28$ & $+0,21$ & $+1,58$ \\
$2006-2009$ & $+3,99$ & $+2,91$ & $+2,31$ & $+2,00$ \\
$2010-2013$ & $+2,21$ & $+2,68$ & $+1,48$ & $+1,85$ \\
$2014-2017$ & $+2,39$ & $+2,07$ & $+1,39$ & $+0,95$ \\
\hline
\end{tabular}

На рисунке 2 показано изменение разницы в продолжительности жизни между Москвой и Россией. Заметно, что ее уровень полностью сформировался в период с 1995 по 2005 г., т. е. в период описанных выше разнонаправленных тенденций изменения смертности. После 2005 г., когда в России вслед за Москвой начался интенсивный рост продолжительности жизни, эта разница значительно не изменялась, за исключением 2010 2011 гг. вследствие изменений, связанных с ростом смертности из-за летней жары в 2010 г. [Ревич 2011; Shaposhnikov et al. 2014]. За период с 1999 по 2005 г. разница в продолжительности жизни между Москвой и Россией увеличилась до 8,4 года у мужчин и 4,1 года у женщин и в дальнейшем стабилизировалась на уровне 7,1-8,1 и 3,5-4,6 года соответственно.

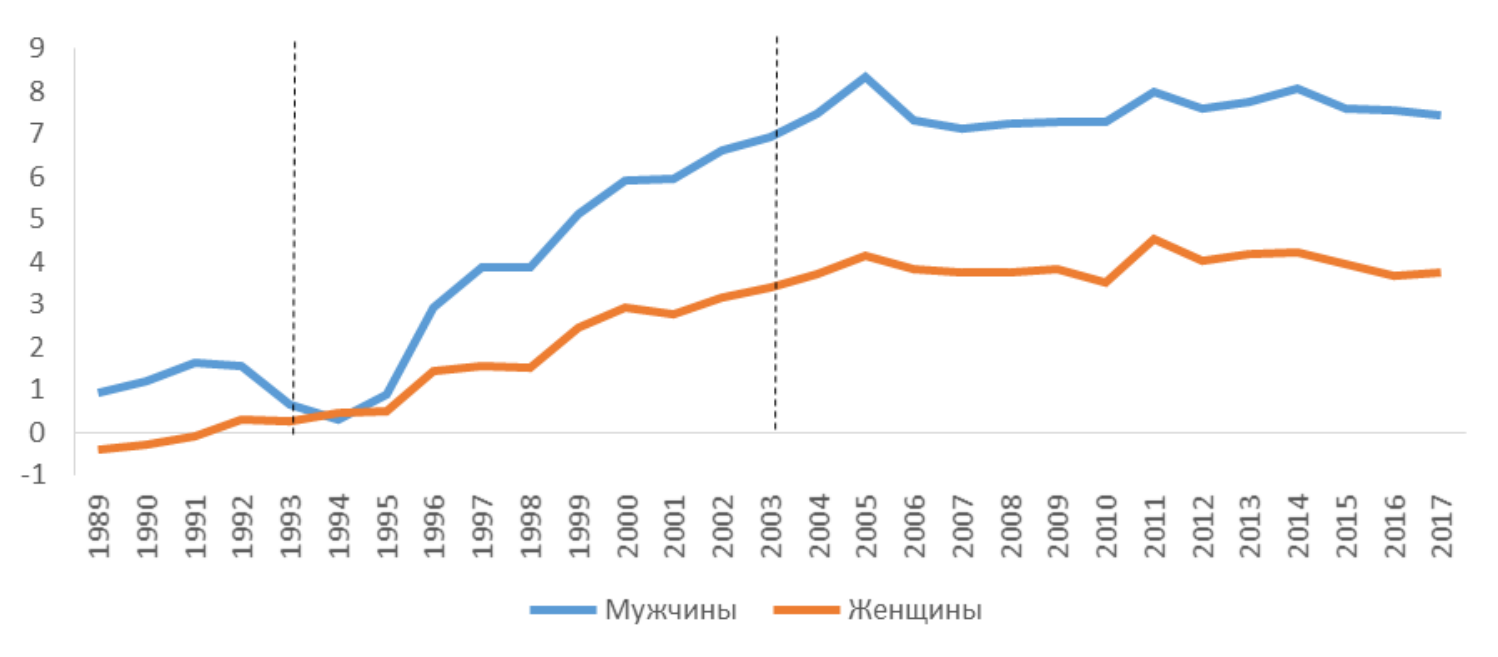

Рисунок 2. Разница в ожидаемой продолжительности жизни между Москвой и Россией (без Москвы), 1989-2017, лет

Всего в нескольких регионах России, помимо Москвы, динамика ОПЖ не характеризовалась устойчивым снижением в конце 1990-х - начале 2000-х годов, среди них Ханты-Мансийский, Ямало-Ненецкий и Таймырский автономные округа, Республики Калмыкия и Якутия. Большинство из этих регионов характеризуются развитой 
добывающей отраслью, в указанный период они, как и Москва, были особенно привлекательны для мигрантов благодаря возможности получения более высоких доходов.

Ожидаемая продолжительность жизни в трудоспособном и пожилом возрасте

Наряду с равномерным ростом продолжительности жизни при рождении увеличивалась и продолжительность жизни в трудоспособном и пожилом возрасте, однако темпы роста и основные закономерности в сравнении с другими территориями несколько отличаются для средних и старших возрастов.

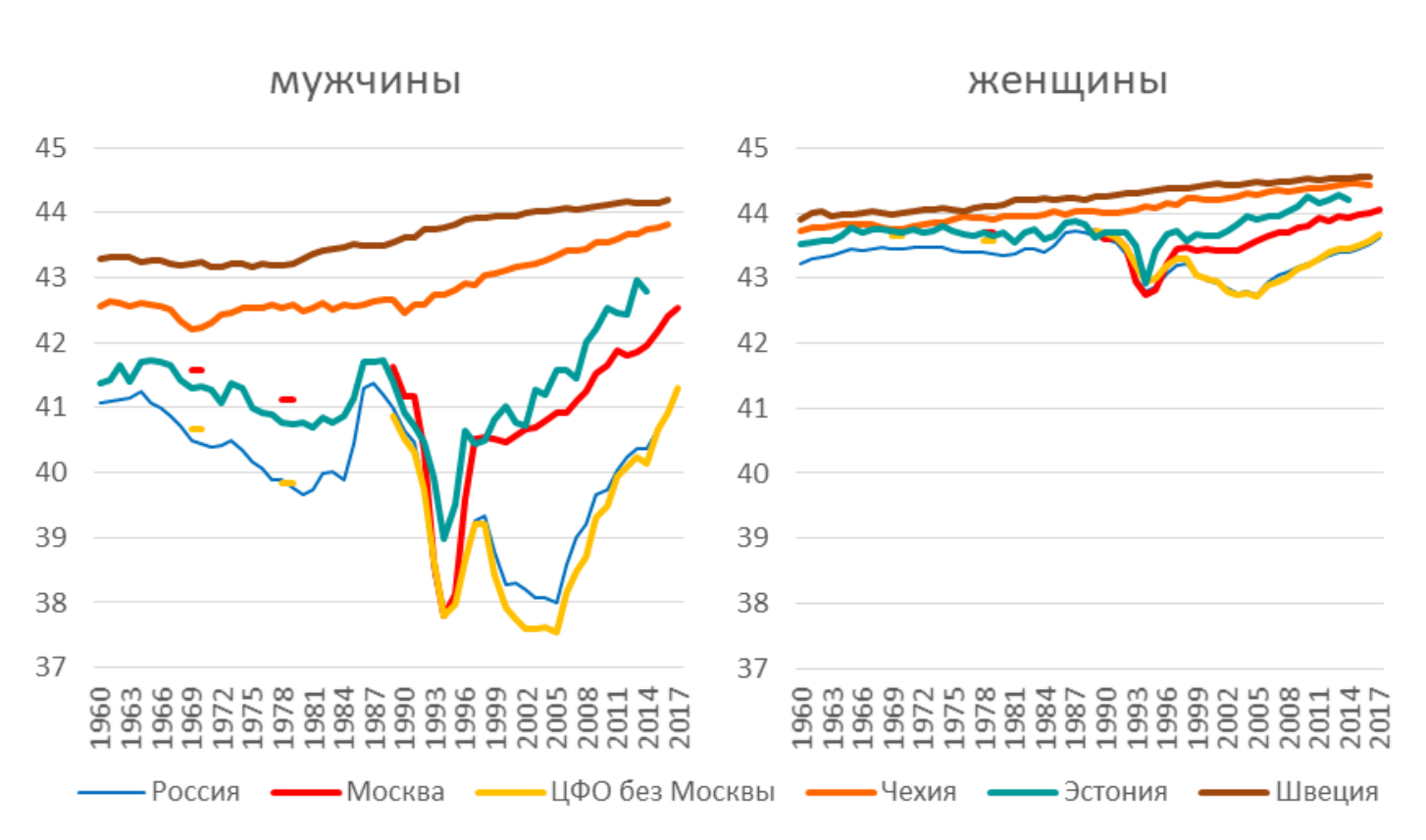

\section{Рисунок 3. Ожидаемая продолжительность жизни в интервале возраста 15-59 лет в Москве, России и некоторых странах, 1960-2017, лет}

Так, несмотря на схожий уровень продолжительности жизни между Москвой и Эстонией в интервале возраста 15-59 лет до начала 1990-х годов, после подъема смертности 1993-1995 гг. наблюдается тенденция к увеличению разницы между мужчинами в Москве и Эстонии (рисунок 3). Смертность в трудоспособном возрасте наиболее заметно выросла в России в период с 1998 по 2005 г., однако в Москве подобного роста не наблюдалось, а с 2000 г. наблюдается устойчивое снижение смертности, которое происходит более низкими темпами, чем в Эстонии и - с 2005 г. - в России. За счет более высоких темпов снижения смертности в России разница в продолжительности жизни между Москвой и Россией с 2005 г. сокращается (рисунок 5). То, что перелом тенденции произошел между 2005 и 2006 гг., видимо, объясняется эффектом регулирования алкогольного рынка [Shkolnikov et al. 2013], введенного в действие в 2006-2007 гг. и имевшего гораздо большее значение для многих регионов России, где уровень смертности от алкогольно-зависимых и внешних причин в 2005 г. был выше, чем для Москвы, где к 2005 г. смертность от этих причин была уже значительно снижена.

Продолжительность жизни москвичей в возрасте 60 лет начала быстро расти с 2004 г., опередив среди мужчин Эстонию, а с 2010 г. и Чехию. В 2017 г. продолжительность жизни в возрасте 60 лет составила 21,4 года у мужчин и 24,5 года у женщин (в России - 16,5 
и 22 года соответственно, в Чехии - 19,7 и 24 года). Особенно быстрый рост продолжительности жизни в пожилом возрасте в Москве пришелся на 2011 г., когда продолжительность жизни мужчин увеличилась на 1,4 года, а женщин - на 0,5 года (рисунок 4), что может быть частично объяснено компенсационным ростом показателя после его кратковременного снижения в результате жары 2010 г., которое, однако, было более выражено у женщин. Разница в продолжительности жизни в возрасте 60 лет, в отличие от более молодых возрастных групп, неуклонно возрастает на протяжении всего рассматриваемого периода (рисунок 5).

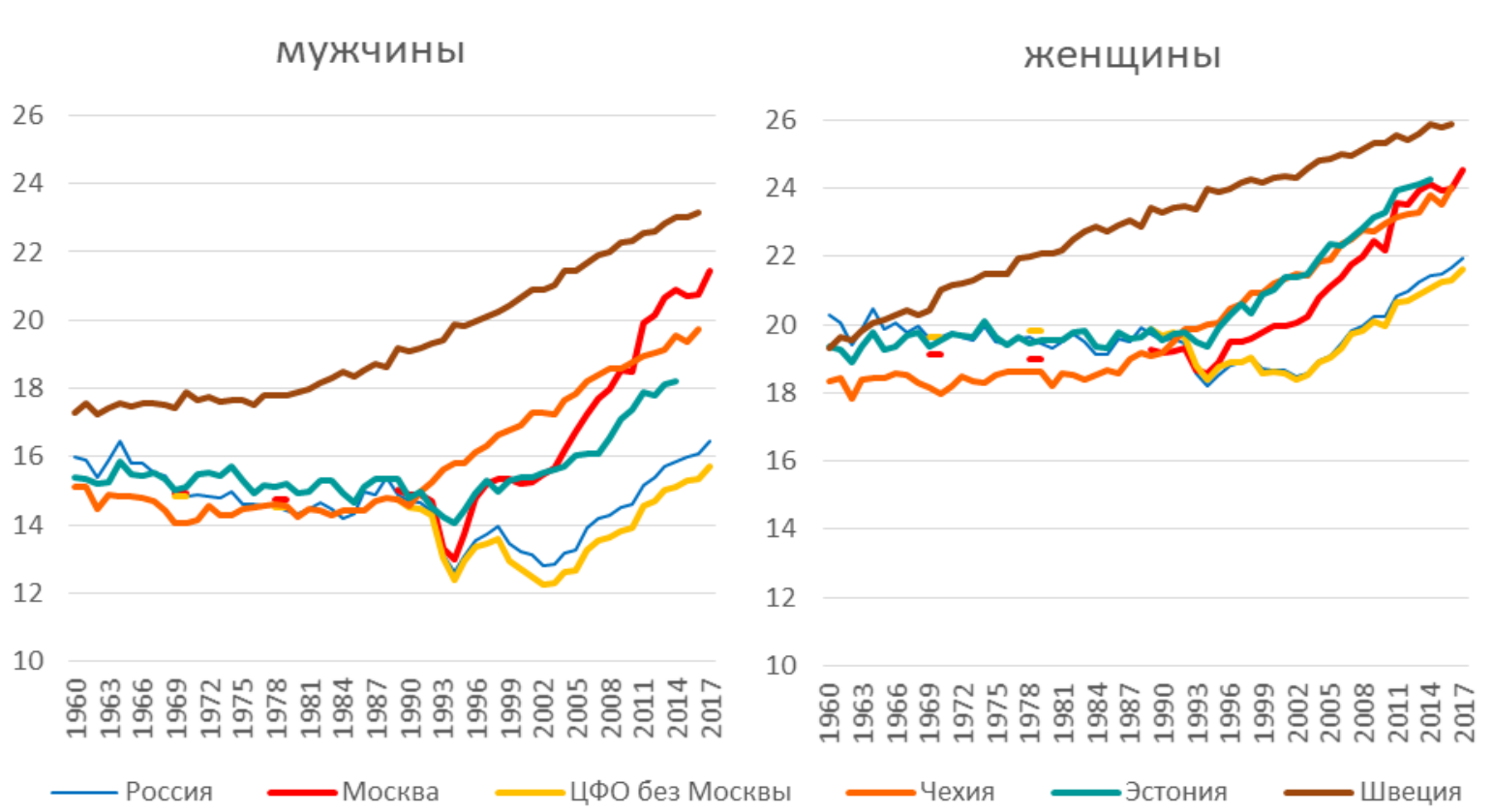

Рисунок 4. Ожидаемая продолжительность жизни в возрасте 60 лет в Москве, ЦФО без Москвы, России и некоторых странах, 1960-2017, лет

Рисунок 5. Разница в ожидаемой продолжительности жизни между Москвой и Россией (без Москвы), 1989-2017, лет 


\section{Смертность в стариих возрастах: проблемы качества данных и наблюдаемая динамика}

Еще более интенсивный рост продолжительности жизни отмечается в возрастных группах старше 60 лет. Так, с 2011 г. в возрасте 80 лет продолжительность жизни московских мужчин является самой высокой среди стран, данные по которым представлены в Human Mortality Database, что противоречит высокой смертности в более младших возрастах и позволяет сделать вывод о существенном занижении смертности пожилого населения Москвы, вероятнее всего вследствие завышения численности населения соответствующего возраста [Папанова и др. 2017].

Таблица 2. Сопоставление численности населения 1912 года рождения и ранее по переписи 2002 г. и числа умерших соответствующих когорт за 2002-2016 гг. в Москве

\begin{tabular}{|c|c|c|c|c|c|c|c|}
\hline Год рождения & 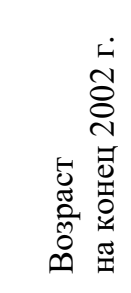 & 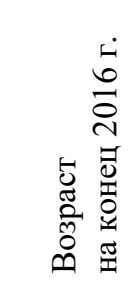 & 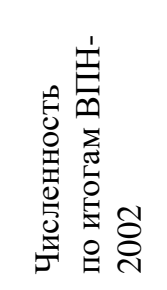 & 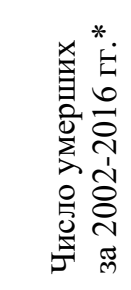 & 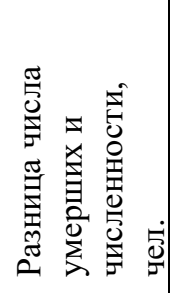 & 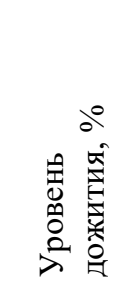 & 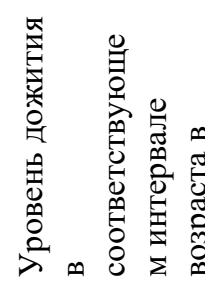 \\
\hline \multicolumn{8}{|c|}{ Мужчины } \\
\hline 1912 & 90 & 104 & 2265 & 1694 & 571 & $25 \%$ & $0,25 \%$ \\
\hline 1911 & 91 & 105 & 1553 & 1176 & 377 & $24 \%$ & $0,16 \%$ \\
\hline 1910 & 92 & 106 & 1240 & 857 & 383 & $31 \%$ & $0,10 \%$ \\
\hline 1909 & 93 & 107 & 733 & 550 & 183 & $25 \%$ & $0,06 \%$ \\
\hline 1908 & 94 & 108 & 523 & 401 & 122 & $23 \%$ & $0,04 \%$ \\
\hline 1907 & 95 & 109 & 374 & 239 & 135 & $36 \%$ & $0,03 \%$ \\
\hline 1906 & 96 & 110 & 281 & 185 & 96 & $34 \%$ & $0,00 \%$ \\
\hline 1905 и ранее & $\begin{array}{l}97 \text { и } \\
\text { старше }\end{array}$ & $\begin{array}{l}111 \text { и } \\
\text { старше }\end{array}$ & 636 & 211 & 425 & $67 \%$ & - \\
\hline $\begin{array}{l}\text { Всего } 1912 \text { г.р. и } \\
\text { ранее }\end{array}$ & $\begin{array}{l}90 \text { и } \\
\text { старше }\end{array}$ & $\begin{array}{l}104 \text { и } \\
\text { старше }\end{array}$ & 7605 & 5313 & 2292 & $30 \%$ & - \\
\hline \multicolumn{8}{|c|}{ Женщины } \\
\hline 1912 & 90 & 104 & 7864 & 6892 & 972 & $12 \%$ & $0,70 \%$ \\
\hline 1911 & 91 & 105 & 5108 & 4520 & 588 & $12 \%$ & $0,45 \%$ \\
\hline 1910 & 92 & 106 & 4218 & 3560 & 658 & $16 \%$ & $0,28 \%$ \\
\hline 1909 & 93 & 107 & 2726 & 2360 & 366 & $13 \%$ & $0,18 \%$ \\
\hline 1908 & 94 & 108 & 1917 & 1639 & 278 & $15 \%$ & $0,11 \%$ \\
\hline 1907 & 95 & 109 & 1339 & 1115 & 224 & $17 \%$ & $0,07 \%$ \\
\hline 1906 & 96 & 110 & 940 & 731 & 209 & $22 \%$ & $0,04 \%$ \\
\hline 1905 и ранее & $\begin{array}{l}97 \text { и } \\
\text { старше }\end{array}$ & $\begin{array}{l}111 \text { и } \\
\text { старше }\end{array}$ & 1823 & 1064 & 759 & $42 \%$ & - \\
\hline $\begin{array}{l}\text { Всего } 1912 \text { г.р. и } \\
\text { ранее }\end{array}$ & $\begin{array}{l}90 \text { и } \\
\text { старше }\end{array}$ & $\begin{array}{l}104 \text { и } \\
\text { старше }\end{array}$ & 25935 & 21881 & 4054 & $16 \%$ & - \\
\hline
\end{tabular}

Источник: Итоги ВПН-2002, База данных управления ЗАГС города Mосквы, Hитап Mortality Database.

* - Для 2002 года включены умершие, зарегистрированные после 09.10.2002

Приведенное в таблице 2 сопоставление численности населения 1912 и более ранних годов рождения по итогам переписи 2002 г. и числа зарегистрированных смертей по данным Управления ЗАГС города Москвы в период с 2002 по 2016 г. показывает особенно значимое завышение численности мужчин, более заметное с увеличением возраста. Так, среди мужчин 1912 года рождения с 2002 по 2016 г. уровень дожития составил 25\% 
(в Швеции в соответствующем возрастном интервале - 0,25\%), 1906 года рождения - 34\%, для поколений, рожденных до 1905 г., это значение составляет уже 67\%. Можно допустить, что часть мужчин и женщин более младших возрастных групп к концу 2016 года еще находились в живых, что не реалистично для населения более ранних годов рождения, возраст которых к 2016 г. превышает 110 лет, особенно с учетом уровня дожития, наблюдаемого в Швеции.

Таблица 3. Сопоставление численности населения 1915 года рождения и ранее по переписи 2010 года и количества умерших соответствующих когорт за 2010-2016 гг. в городе Москве

\begin{tabular}{|c|c|c|c|c|c|c|c|}
\hline Год рождения & 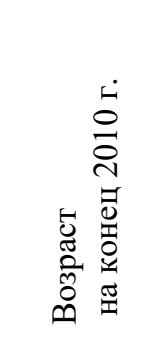 & 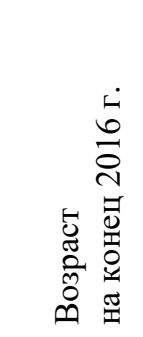 & 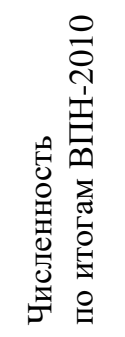 & 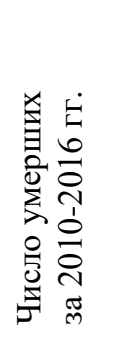 & 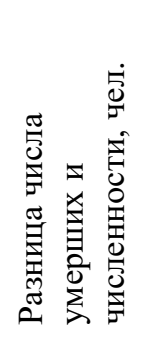 & 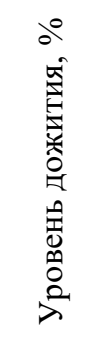 & 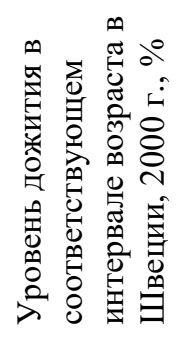 \\
\hline \multicolumn{8}{|l|}{ Мужчины } \\
\hline 1915 & 95 & 101 & 545 & 286 & 259 & 48 & 6,4 \\
\hline 1914 & 96 & 102 & 439 & 236 & 203 & 46 & 5,3 \\
\hline 1913 & 97 & 103 & 392 & 185 & 207 & 53 & 4,3 \\
\hline 1912 & 98 & 104 & 276 & 114 & 162 & 59 & 3,5 \\
\hline 1911 & 99 & 105 & 203 & 53 & 150 & 74 & 2,9 \\
\hline 1910 & 100 & 106 & 119 & 39 & 80 & 67 & 2,2 \\
\hline 1909 & 101 & 107 & 47 & 13 & 34 & 72 & 1,9 \\
\hline 1908 & 102 & 108 & 35 & 18 & 17 & 49 & 1,7 \\
\hline 1907 & 103 & 109 & 18 & 2 & 16 & 89 & 1,6 \\
\hline 1906 & 104 & 110 & 14 & 4 & 10 & 71 & 9,1 \\
\hline 1905 и ранее & $\begin{array}{l}105 \text { и } \\
\text { старше }\end{array}$ & $\begin{array}{l}111 \text { и } \\
\text { старше }\end{array}$ & 204 & 10 & 194 & 95 & - \\
\hline $\begin{array}{l}\text { Всего } 1915 \text { и } \\
\text { ранее }\end{array}$ & $\begin{array}{l}98 \text { и } \\
\text { старше }\end{array}$ & $\begin{array}{l}106 \text { и } \\
\text { старше }\end{array}$ & 2292 & 960 & 1332 & 58 & - \\
\hline \multicolumn{8}{|l|}{ Женщины } \\
\hline 1915 & 95 & 101 & 1900 & 1331 & 569 & 30 & 10,4 \\
\hline 1914 & 96 & 102 & 1617 & 1163 & 454 & 28 & 8,4 \\
\hline 1913 & 97 & 103 & 1209 & 806 & 403 & 33 & 6,8 \\
\hline 1912 & 98 & 104 & 809 & 504 & 305 & 38 & 5,5 \\
\hline 1911 & 99 & 105 & 512 & 270 & 242 & 47 & 4,4 \\
\hline 1910 & 100 & 106 & 347 & 173 & 174 & 50 & 3,5 \\
\hline 1909 & 101 & 107 & 157 & 72 & 85 & 54 & 2,8 \\
\hline 1908 & 102 & 108 & 116 & 58 & 58 & 50 & 2,3 \\
\hline 1907 & 103 & 109 & 70 & 21 & 49 & 70 & 1,8 \\
\hline 1906 & 104 & 110 & 51 & 12 & 39 & 76 & 1,6 \\
\hline 1905 и ранее & $\begin{array}{l}105 \text { и } \\
\text { старше }\end{array}$ & $\begin{array}{l}111 \text { и } \\
\text { старше }\end{array}$ & 322 & 16 & 306 & 95 & 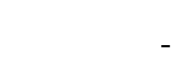 \\
\hline $\begin{array}{l}\text { Всего } 1915 \text { и } \\
\text { ранее }\end{array}$ & $\begin{array}{l}98 \text { и } \\
\text { старше }\end{array}$ & $\begin{array}{l}106 \text { и } \\
\text { старше }\end{array}$ & 7110 & 4426 & 2684 & 38 & - \\
\hline
\end{tabular}

Источник: Итоги ВПН-2002, База данных управления ЗАГС города Москвы, Huтаn Mortality Database.

Примечание: * - Для 2010 г. включень умершие, зарегистрированнье после 14.10.2010.

Сопоставление численности населения по итогам переписи 2010 г. и числа умерших соответствующих годов рождения показывает в целом аналогичную картину возрастания расхождений в дожитии между Россий и Швецией с возрастом как среди мужчин, так и 
среди женщин (таблица 3). Так, уровень дожития когорт 1915 года рождения от возраста 95 лет до 101 года составляет 48\% для мужчин и 30\% для женщин, что в 7,4 и 2,9 раза соответственно выше, чем в Швеции по данным HMD.

Что касается возрастных особенностей смертности в пожилом возрасте, следует прежде всего отметить, что в Москве сильнее проявляется наблюдаемое в России по данным статистики смертности превышение смертности женщин над смертностью мужчин в пожилых возрастах [Папанова и др. 2017]. Наблюдаемые коэффициенты смертности в старших возрастах в России и, особенно, в Москве выглядят слишком низкими на фоне высокого уровня смертности взрослого населения. При сравнении возрастных коэффициентов смертности в старших возрастах в Москве с другими странами, например, со Швецией, уровень смертности в возрасте старше 80-90 лет в Москве выглядит неправдоподобно низким (рисунок 6). Особенно это заметно среди мужчин, возрастные коэффициенты смертности которых в возрасте 80-82 года ниже, чем в Швеции. Кроме того, после 90 лет для кривой смертности в Москве характерны значительные флуктуации, также особенно заметные среди мужчин. При этом численность пожилого населения Швеции сопоставима с численностью населения Москвы, а значит, характер изменения показателей в старшем возрасте в Москве не может быть объяснен низкой численностью пожилого населения.

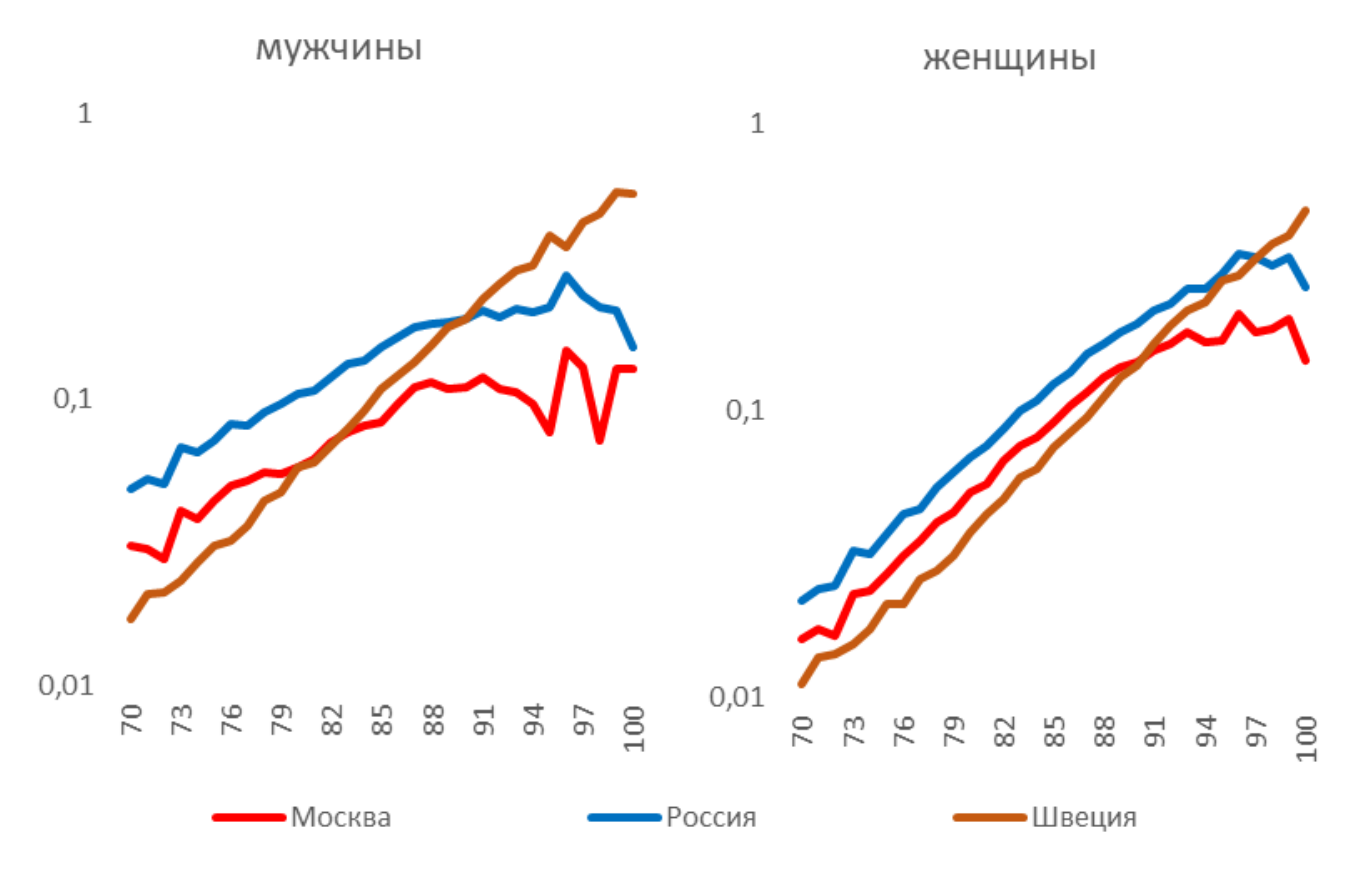

Рисунок 6. Возрастные коэффициенты смертности в возрасте старше 70 лет, Москва, Россия и Швеция, 2015 год

Примечание: Данные показаны в логарифмической шкале.

Как показано на рисунке 7, динамика возрастных коэффициентов смертности характеризуется быстрым снижением показателей в самых старших возрастных группах (старше 80 лет) в течение последнего периода роста продолжительности жизни. В Москве это особенно заметно среди мужчин, а начало снижения показателей приходится на 1993 г., уровень Швеции был достигнут уже в середине 2000-х годов. На фоне высокой смертности 
в младших возрастных группах следовало бы ожидать более выраженного снижения смертности в младших пожилых возрастах (60-75 лет), более восприимчивых к воздействию профилактических мер и своевременной медицинской помощи - с учетом достигнутого уровня продолжительности жизни на настоящий момент предотвратимой, как правило, считается смертность в возрасте до 75 лет [Eurostat 2018].

\section{мужчины}

Россия без Москвы

30000

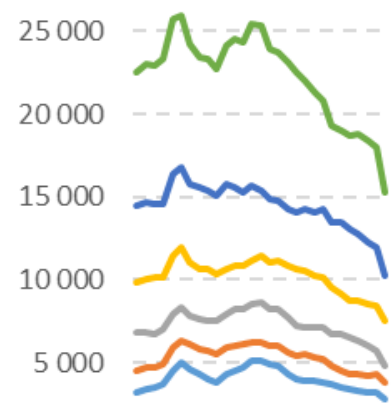

0

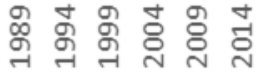

Москва

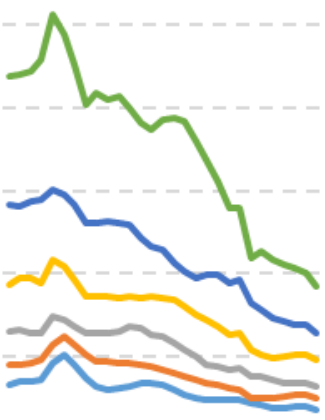

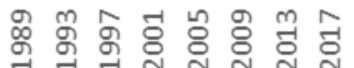

женщинь

Россия без Москвы

25000

20000

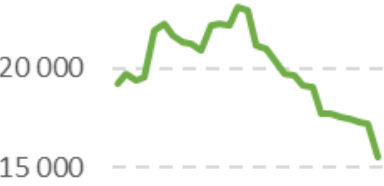

10000

5000
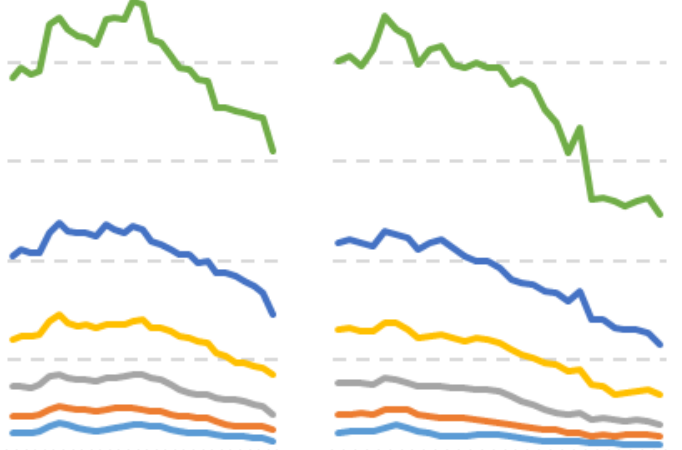

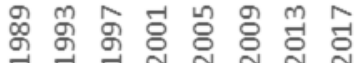

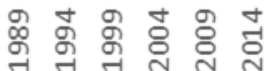

Москва

Эстония
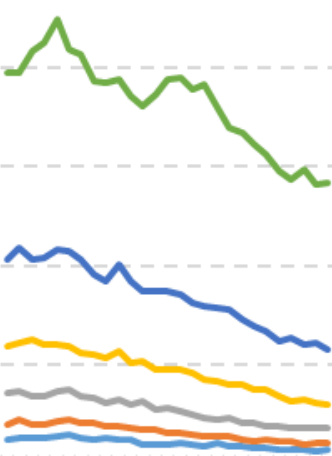

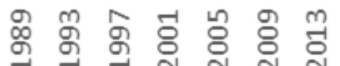

Швеция
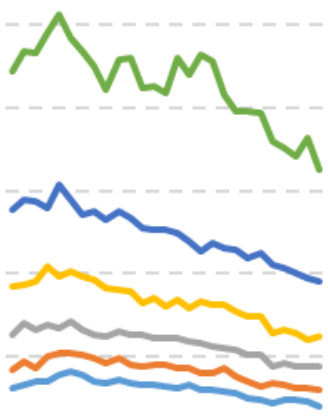

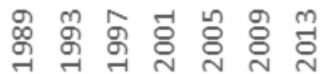

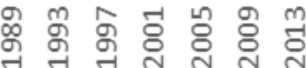
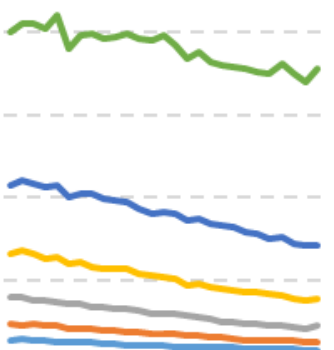

Швеция
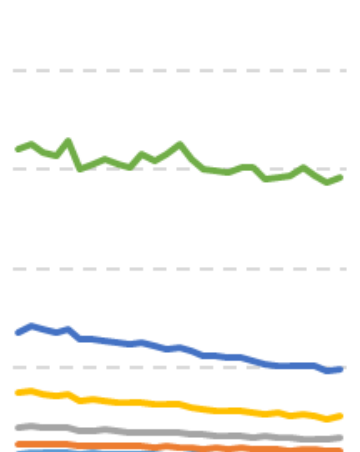

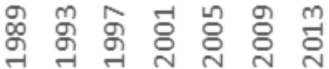

Рисунок 7. Возрастные коэффициенты смертности в возрастах старше 60 лет, на 100 тыс. населения 


\section{ВОЗРАСТНЫЕ КОМПОНЕНТЫ ИЗМЕНЕНИЯ ОЖИДАЕМОЙ ПРОДОЛЖИТЕЛЬНОСТИ ЖИЗНИ В МОСКВЕ}

\section{A) 1989-1994 22.}

В период до 1994 г. характер изменения ОПЖ в Москве и России был схожим: снижение продолжительности жизни происходило главным образом за счет роста смертности в трудоспособных возрастах, однако в Москве негативный вклад возрастов от 20 до 55 лет был выше, чем в России ( 86 и 78\% соответственно среди мужчин и 79 и $58 \%$ среди женщин). Среди женщин при этом заметно ниже вклад пожилых возрастов в наблюдаемое снижение продолжительности жизни: на возраст старше 60 лет в Москве приходится 21\% снижения ОПЖ, в России - $38 \%$ (рисунок 8 ).

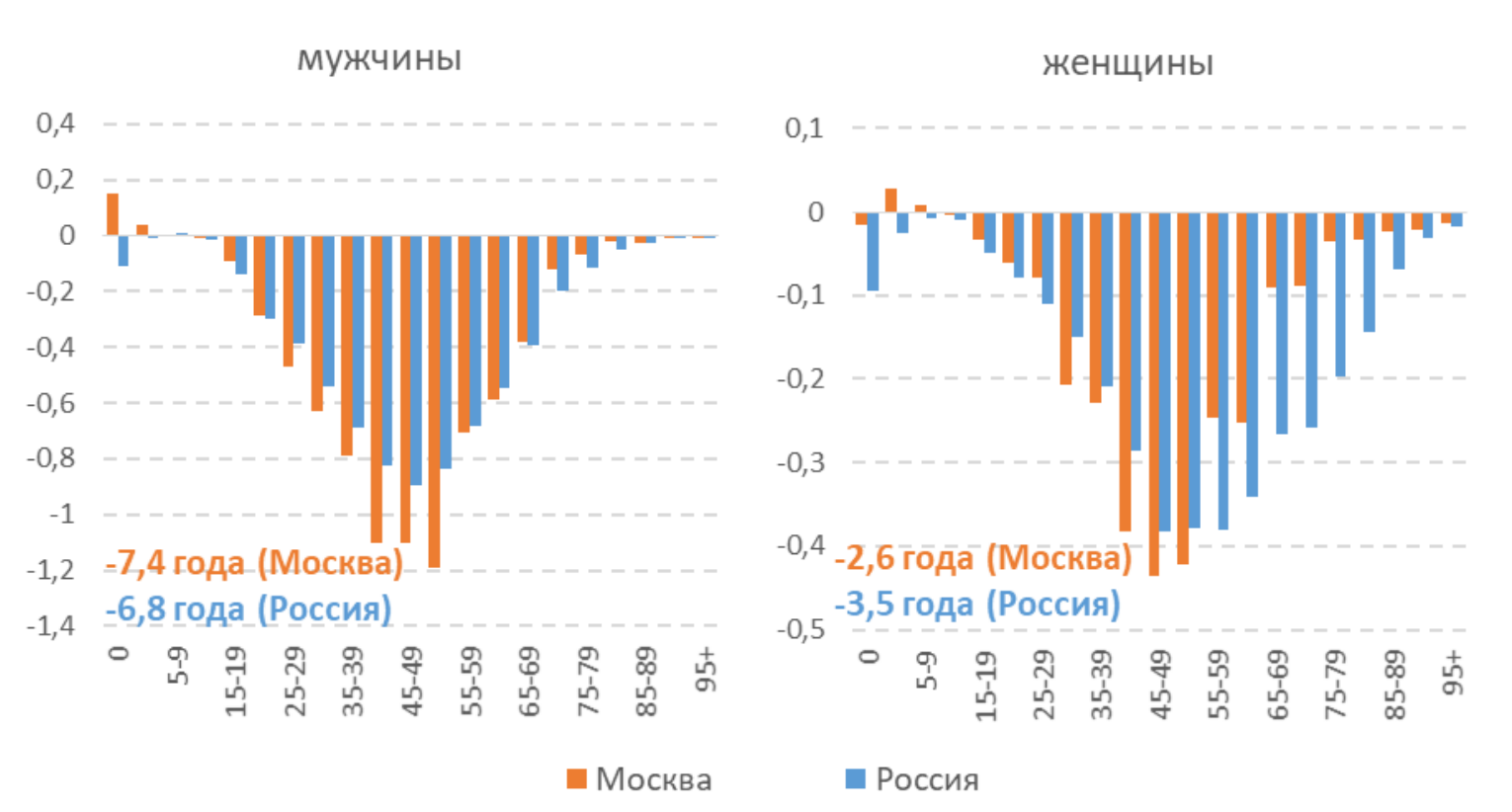

Рисунок 8. Вклад возрастных групп в изменение ожидаемой продолжительности жизни в Москве и в России в 1989 - 1994 гг., лет

\section{Б) 1995-1998 22.}

В этот период разница в продолжительности жизни между Москвой и Россией увеличивалась за счет более быстрого снижения смертности в Москве. Результаты декомпозиции показывают, что большая часть прироста в этот период как в Москве, так и в России в целом приходится на население в трудоспособном возрасте (74\%), при этом в абсолютных значениях в большинстве возрастных групп в Москве прирост был в среднем в два раза выше по сравнению с Россией (рисунок 9, верхняя панель).

\section{B) 1999-2003 22.}

За 1999-2003 гг. продолжительность жизни в России снизилась на 2,7 и 1,2 года у мужчин и женщин соответственно, что происходило за счет роста смертности во всех возрастных группах, главным образом в возрасте 25-64 года. В Москве в этот период в указанном возрастном интервале (25-64 года) не наблюдалось выраженных изменений, в возрасте до 34 лет у мужчин и до 24 лет у женщин, а также в более старших возрастах происходило 
снижение смертности, в отдельных возрастных группах отмечался небольшой рост. В результате продолжительность жизни в Москве за указанный период почти не изменилась.

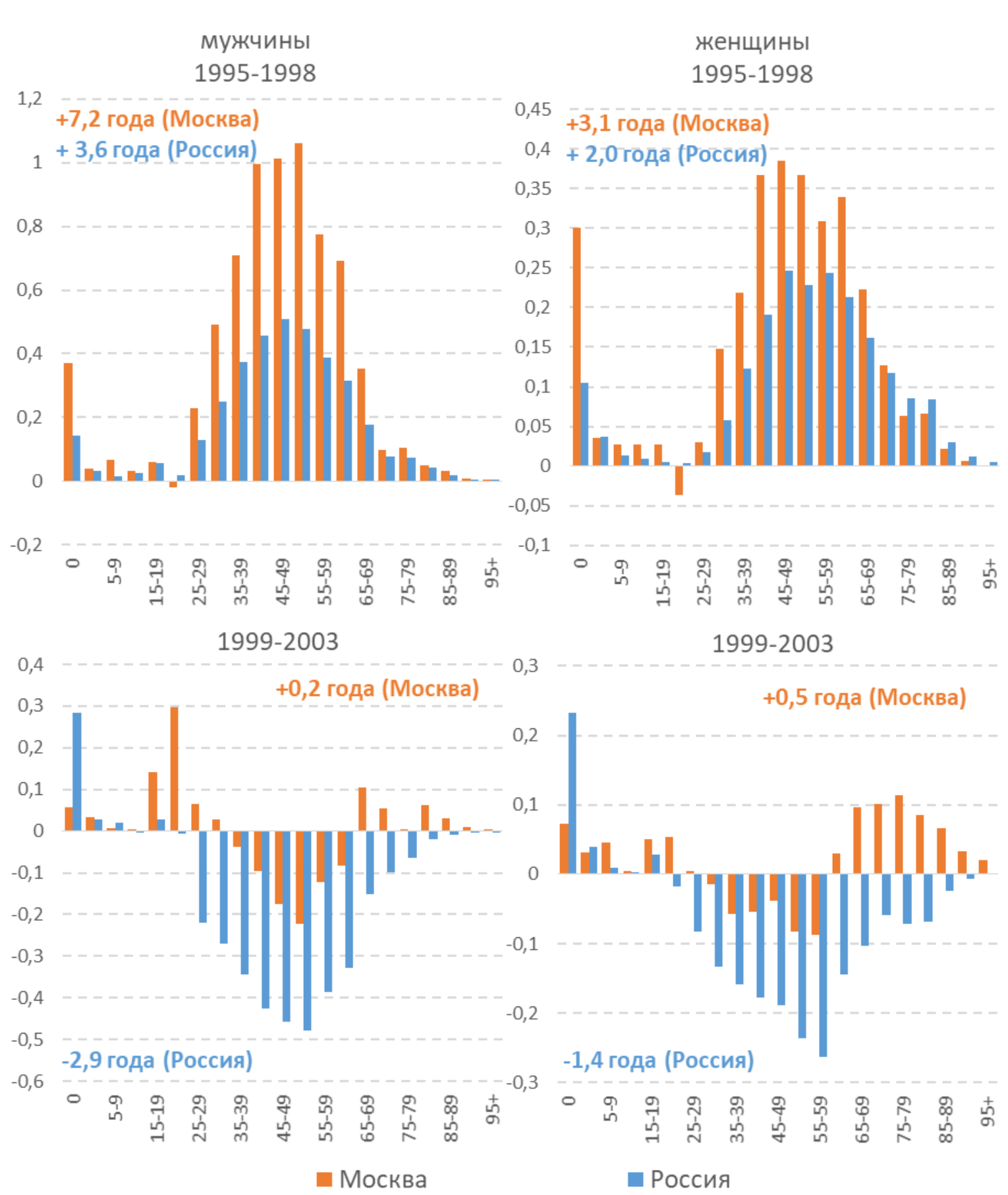

Рисунок 9. Вклад возрастных групп в изменение ожидаемой продолжительности жизни в Москве и в России в 1995-1998 гг. (верхняя панель) и 1999-2003 гг. (нижняя панель), лет

\section{Г) 2004-2005 22.}

С 2004 г. продолжительность жизни в Москве начала быстро расти, в России в этом году также наблюдался прирост, однако менее заметный по сравнению с Москвой. Указанные 
изменения происходили в обоих населениях главным образом за счет младенческой смертности и смертности в возрасте после 40 лет, в том числе и в пожилом возрасте.

\section{Д) 2006-2017 22.}

Рост продолжительности жизни в 2005-2017 гг. в Москве и России среди мужчин происходил главным образом за счет населения трудоспособного возраста, среди женщин возрастной профиль изменений в ОПЖ смещен в сторону пожилого возраста. При этом вклад снижения смертности в возрасте старше 70 лет в Москве существенно выше по сравнению с Россией как у мужчин, так и женщин (рисунок 10).

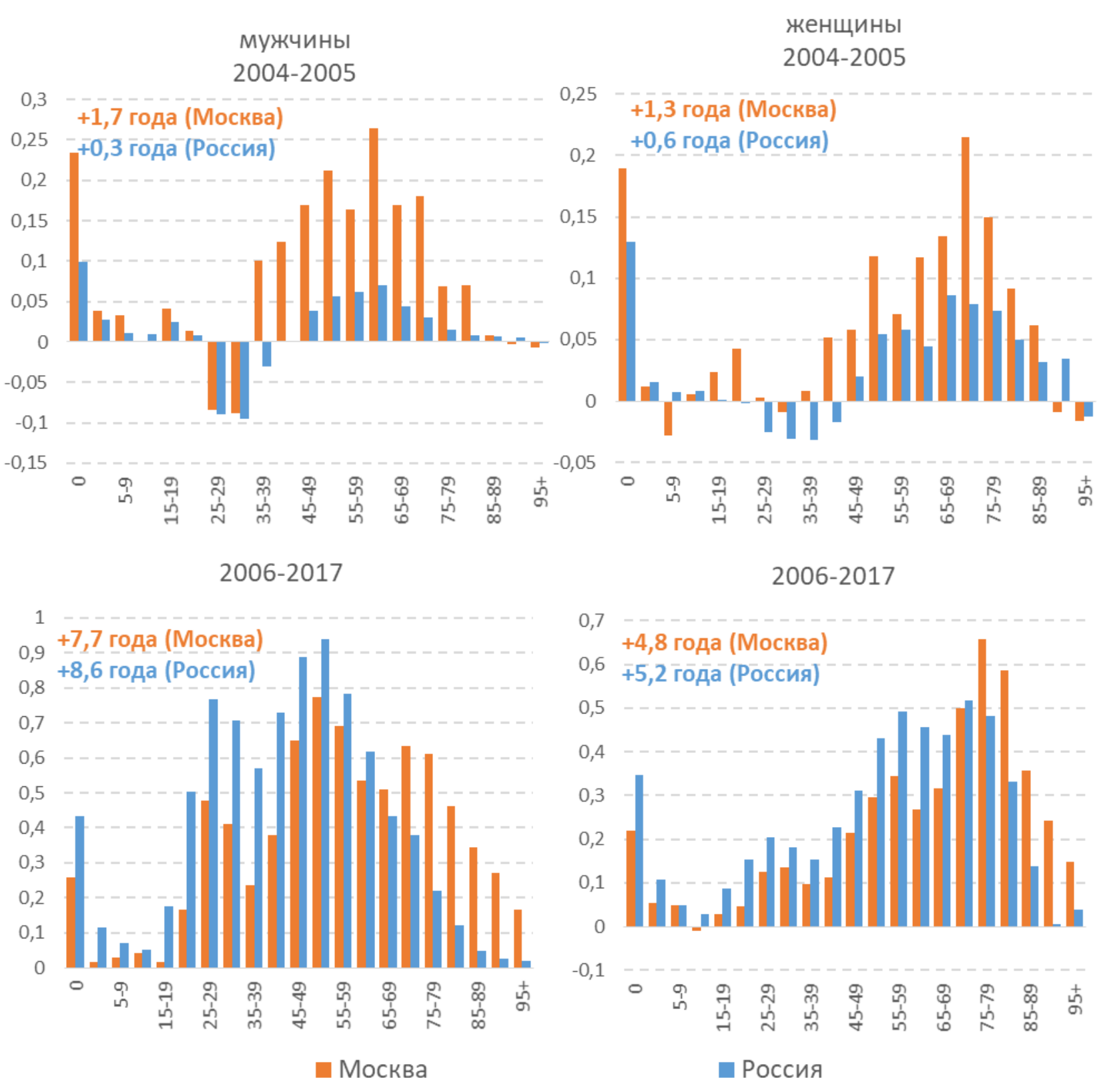

Рисунок 10. Вклад возрастных групп в изменение ожидаемой продолжительности жизни в Москве и в России в 2004-2005 гг. (верхняя панель) и 2006-2017 гг. (нижняя панель), лет 
Таким образом, характер изменений смертности в Москве, который в период с середины 1990-х до середины 2000-х годов существенно отличался от тенденций, наблюдавшихся по России в среднем, был обусловлен более низкой смертностью населения в средних возрастах. Впоследствии главный акцент смещается на смертность пожилого населения.

\section{ОБЩИЕ ТЕНДЕНЦИИ И СТРУКТУРА ПРИЧИН СМЕРТИ}

Структура смертности по причинам смерти в Москве в целом характеризуется теми же тенденциями, которые характеры и для России, а именно высоким уровнем смертности от болезней системы кровообращения, которые играют основную роль в отставании России и Москвы по уровню продолжительности жизни и определяют динамику общей смертности [Вишневский, Андреев, Тимонин 2016]. Смертность от болезней системы кровообращения (БСК) в Москве значительно не отличалась от среднероссийского уровня как до 1989 г., так и вплоть до подъема смертности в начале 1990-х годов, который главным образом был обусловлен подъемом смертности от болезней системы кровообращения и внешних причин смерти (таблица 2 Приложения). В 1996 г. стандартизованный коэффициент смертности (СКС) от БСК снизился более заметно, чем в России, после чего динамика показателя характеризуется устойчивой тенденцией к снижению в отличие от большинства регионов России. Уровень смертности от БСК в Москве близок к показателю в Эстонии, однако существенно отстает от стран с высокой продолжительностью жизни, например, от Швеции (рисунок 11), где СКС более чем в 2 раза ниже, чем в Москве. Это особенно характерно для смертности от ишемической болезни сердца.

Смертность от цереброваскулярных болезней в Москве снижается медленнее, чем в России или Эстонии. Смертность от прочих болезней системы кровообращения в Москве характеризуется большими флуктуациями и по уровню большую часть периода существенно ниже, чем в России или Эстонии, где уровень смертности от данной причины смерти растет.

Доля болезней системы кровообращения в СКС от всех причин в Москве, как и в России, составляет более 50\% (таблица 4). Среди женщин после 2013 г. наблюдается снижение доли БСК до 44-49\%, что более заметно в России, в то время как устойчивое снижение смертности от болезней системы кровообращения в странах с высокой продолжительностью жизни привело к тому, что она сравнялась со смертностью от злокачественных новообразований и составляет порядка $30 \%$ (рисунок 14).

Уровень смертности от новообразований в Москве ближе к уровню европейских стран. При этом среди мужчин СКС к концу периода на треть ниже, чем в Эстонии, а среди женщин в среднем на 10\% выше, чем в России в целом (рисунок 12). При этом следует отметить, что СКС женщин от новообразований в России в среднем на 4\% ниже уровня, наблюдаемого в Швеции. Смертность от новообразований в Москве снижается более заметными темпами по сравнению с Россией как среди мужчин, так и среди женщин, при этом в 1989-1990 гг. показатель в Москве среди мужчин был на 16\% выше, чем в Москве, а 
среди женщин - на 30-40\%. Доля новообразований в СКС от всех причин в Москве за рассматриваемый период выросла среди женщин и почти не изменилась среди мужчин.

мужчины

Болезни системы кровообращения

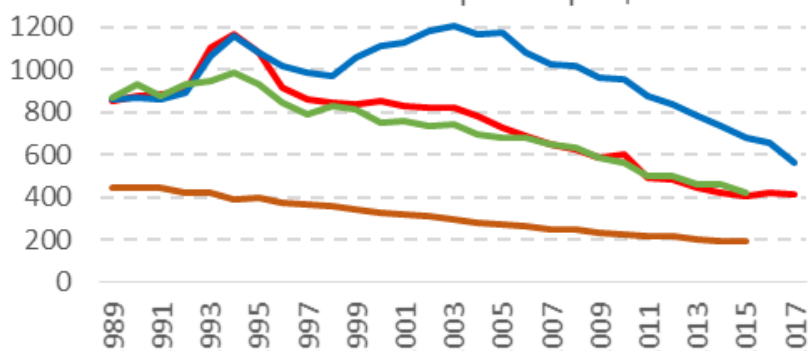

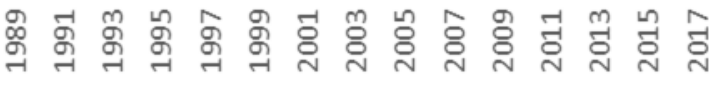

Ишемическая болезнь сердца

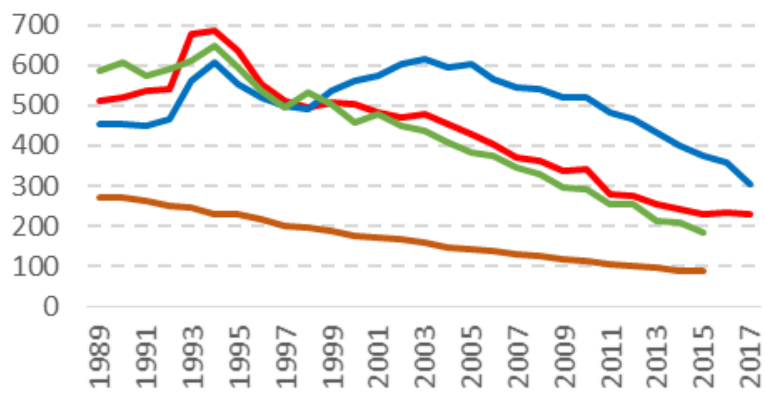

Цереброваскулярные болезни

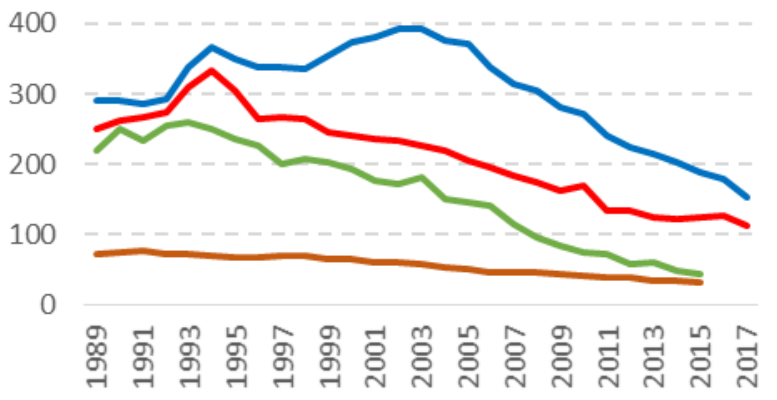

Прочие болезни системы кровообращения

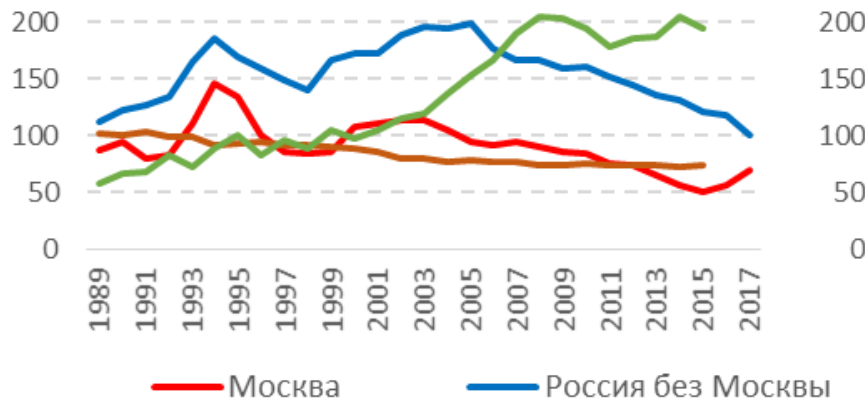

женщины

Болезни системы кровообращения

1200

1000

800

600

400

200

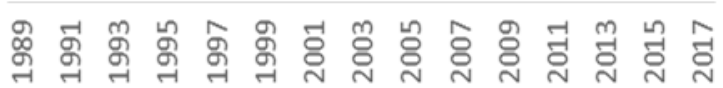

Ишемическая болезнь сердца

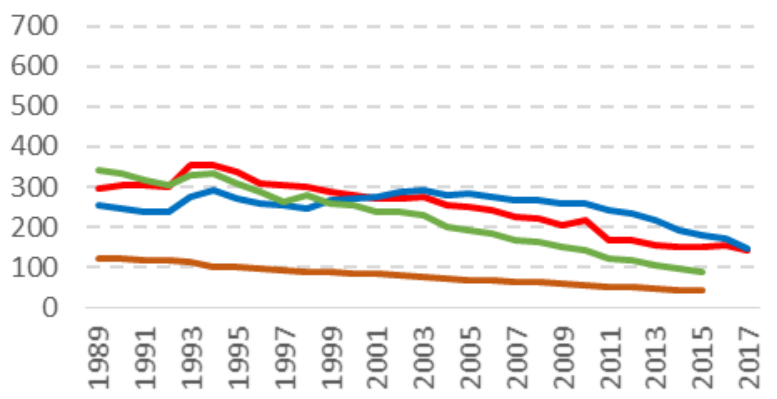

Цереброваскулярные болезни

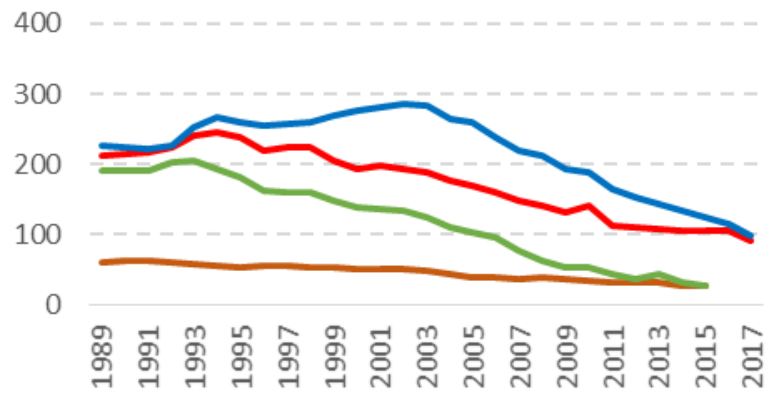

Прочие болезни системы кровообращения

200

150

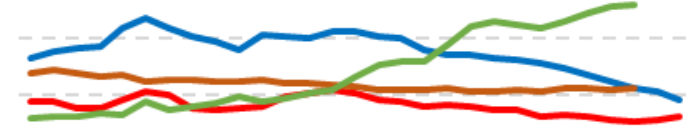

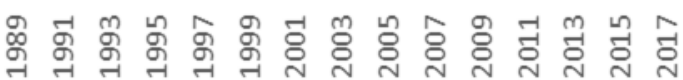

—швеция

— Эстония

Рисунок 11. Стандартизованный коэффициент смертности от болезней системы кровообращения в Москве, России, Эстонии и Швеции, 1989-2017, на 100 тыс. 
Для смертности от злокачественных новообразований некоторых отдельных локализаций в Москве, как и для смертности от новообразований в целом, характерно более быстрое снижение по сравнению с Россией (рисунок 12). Так, СКС от рака трахеи, бронхов и легких, уровень которого, в отличие от рака в целом, не превышал уровня, наблюдаемого в России, снизился на 56\% с 1993 по 2013 г., тогда как в России - на 35\%.

Смертность от внешних причин смерти в Москве с 1970-х годов была ниже среднероссийского уровня. Это особенно заметно в 1969 и 1979 г., а также с начала 2000-х годов, когда разница в СКС возросла до 40\% и к середине 2000-х годов увеличилась до более чем $60 \%$. По данным статистики смертности, с середины 2000-х годов смертность мужчин от внешних причин смерти в Москве в среднем на 40\% ниже смертности в Эстонии, а в 2017 г. - в 2 раза ниже, чем в России (рисунок 13).

Структура смертности от внешних причин смерти в Москве характеризуется высокой и растущей долей повреждений с неопределенными намерениями (ПНН). Максимального абсолютного и относительного уровня вклад этой группы внешних причин смерти достиг во второй половине 1990-х годов (около 40\% всех смертей от внешних причин). С 2000 г. показатель резко снизился, что сопровождалось ростом количества смертей от класса «Симптомы, признаки и отклонения от нормы», т. е. от не установленных причин. Обмен между этими группами причин смерти, характерный для Москвы, ранее неоднократно отмечался исследователями по отношению к указанному периоду (19992001 гг.) [Васин 2015; Архангельский и др. 2006; Семенова, Антонова 2007; Иванова и др. 2013; Gavrilova et al. 2008] и связывается с переходом на МКБ-10. На фоне снижения смертности от внешних причин в целом с середины 2000-х годов вновь увеличивается доля повреждений с неопределенными намерениями, снижается доля убийств и самоубийств. В абсолютных значениях СКС от ПНН, а также от случайных отправлений алкоголем, в Москве вырос в 2016-2017 гг. наряду с резким сокращением количества смертей от не установленных причин. В России также наблюдается тенденция к росту доли умерших от ПНН, однако рост на протяжении всего периода 1989-2017 гг. происходил постепенно, тогда как в Москве изменения носили скачкообразный характер.

В начале 2000-х годов и после 2011 г. отмечается особенно быстрый рост смертности от класса причин смерти «Симптомы, признаки и отклонения от нормы» ${ }^{1}$, т. е. от не установленных причин смерти. Динамика и структура данного показателя будут более подробно рассмотрены в соответствующем разделе. Однако рост количества смертей с не установленными причинами смерти в Москве особенно заметен при рассмотрении структуры СКС по причинам смерти (рисунок 14). Максимальный уровень и доля в СКС смертности от данного класса причин смерти были отмечены в 2015 г.: в результате резкого увеличения количества зарегистрированных умерших, причина смерти которых не была установлена, доля СКС составила 7\% от всех причин среди женщин и $13 \%$ среди мужчин. Это отразилось на структуре причин смерти в виде резкого снижения доли СКС от болезней

\footnotetext{
${ }^{1}$ Полное название этого класса «Симптомы, признаки и отклонения от нормы, выявленные при клинических и лабораторных исследованиях, не классифицированные в других рубриках».
} 
системы кровообращения. Однако в 2016-2017 гг. было отмечено снижение доли СКС от неустановленных причин, сопровождающееся ростом доли БСК.

мужчины

Болезни системы кровообращения

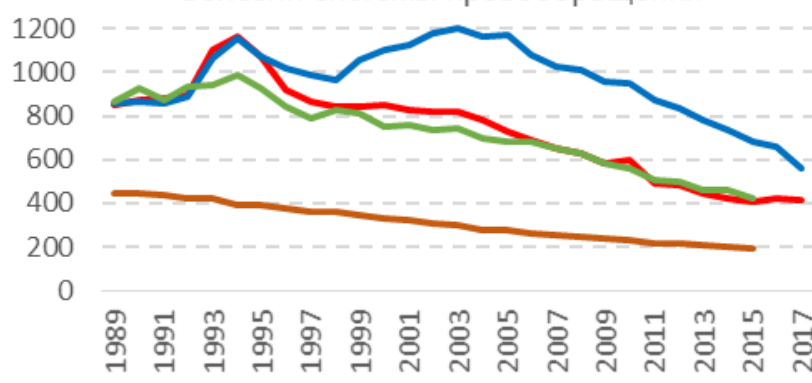

Ишемическая болезнь сердца

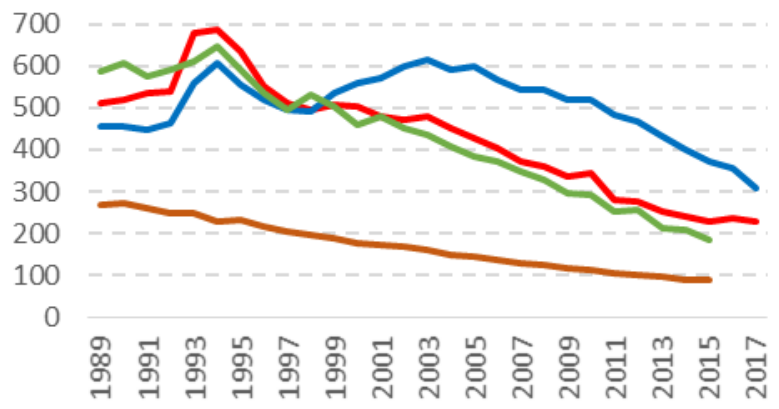

Цереброваскулярные болезни

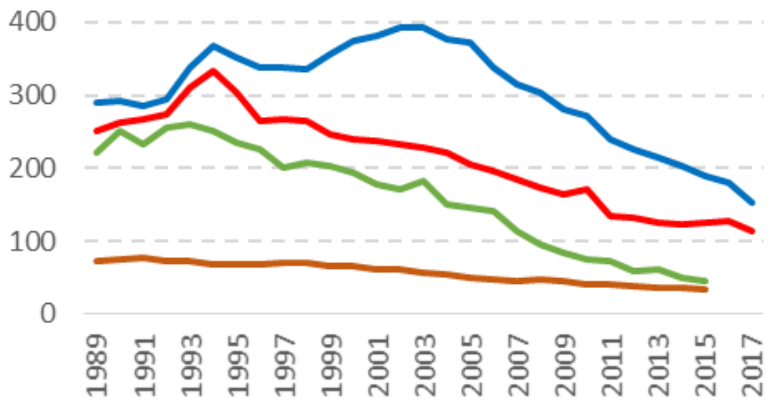

Прочие болезни системы кровообращения

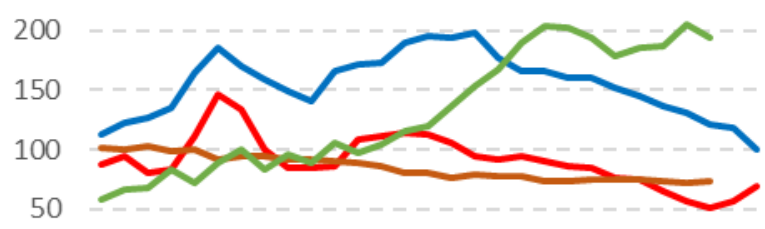

0

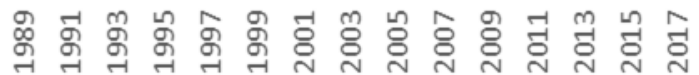

женщины

Болезни системы кровообращения

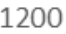

1000

800

600

400

200

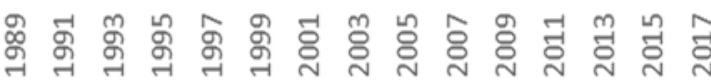

Ишемическая болезнь сердца

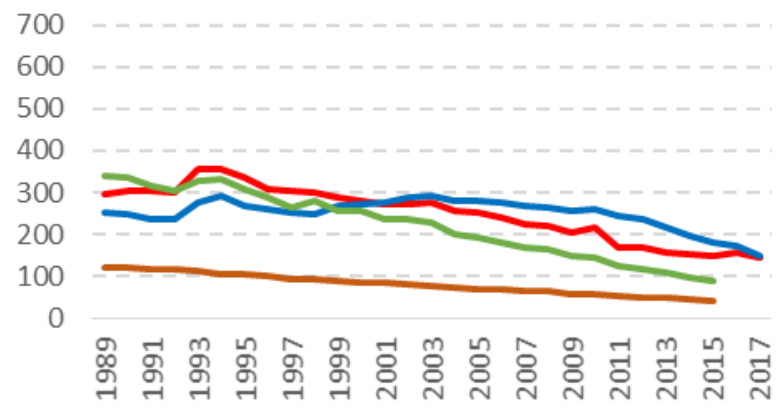

Цереброваскулярные болезни

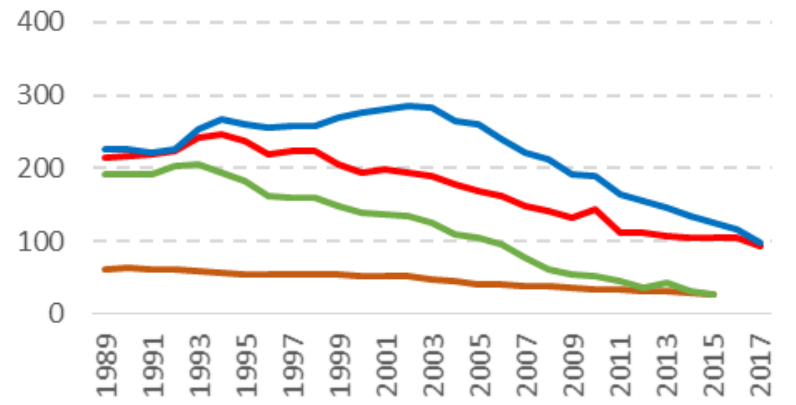

Прочие болезни системы кровообращения

200

150

100

50

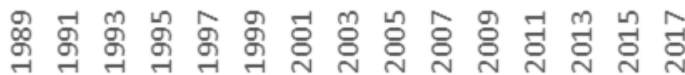

— Швеция

— Эстония

Рисунок 12. Стандартизованный коэффициент смертности от злокачественных новообразований в Москве, России, Эстонии и Швеции, 1989-2017, на 100 тыс. населения 

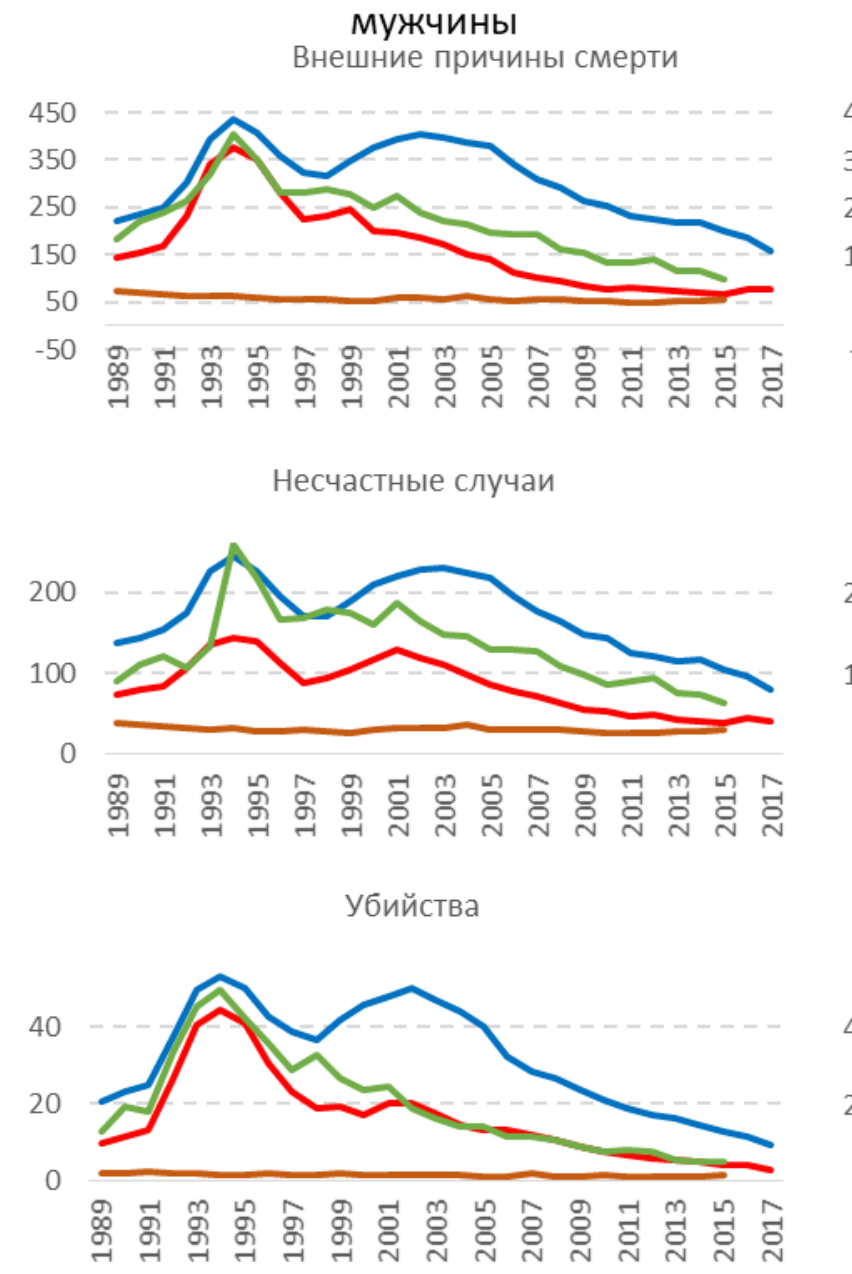

Самоубийства

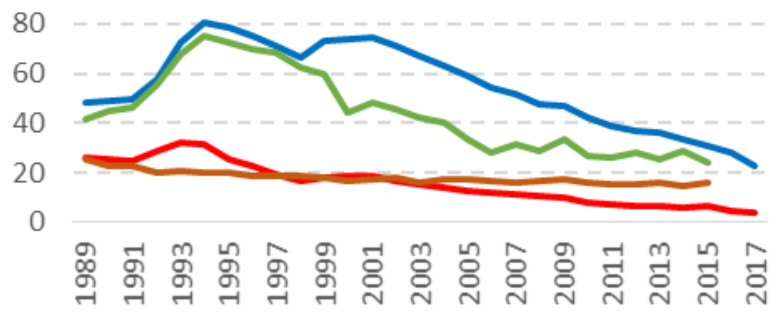

Повреждения с неопределенными

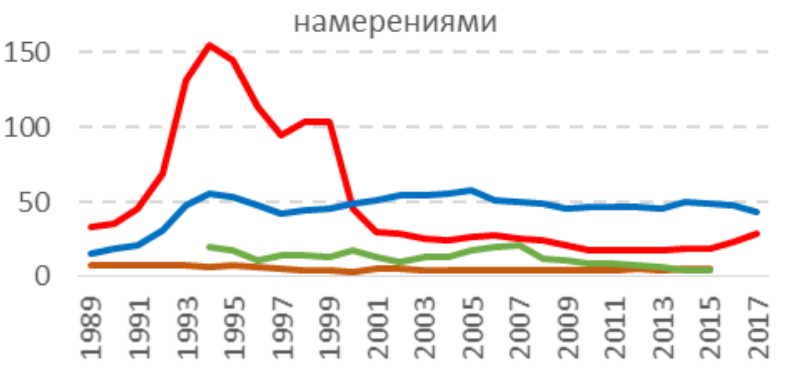

женшинь

Внешние причины смерти

450

350

250

150

50

-50 \%

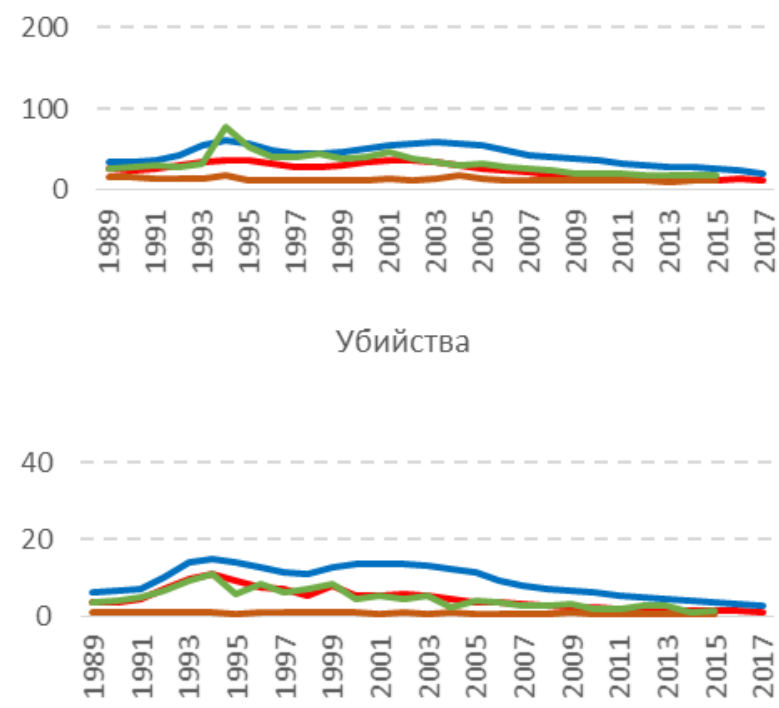

Самоубийства

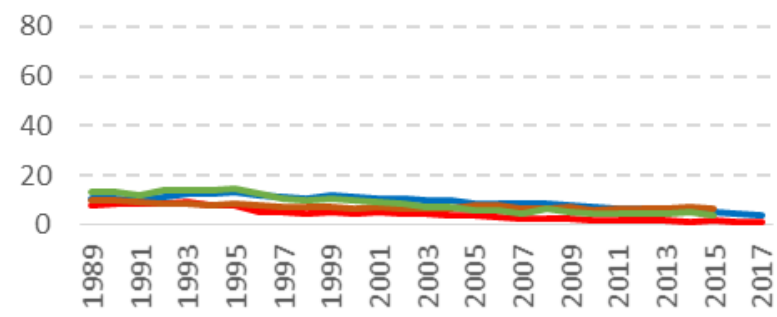

Повреждения с неопределенными намерениями

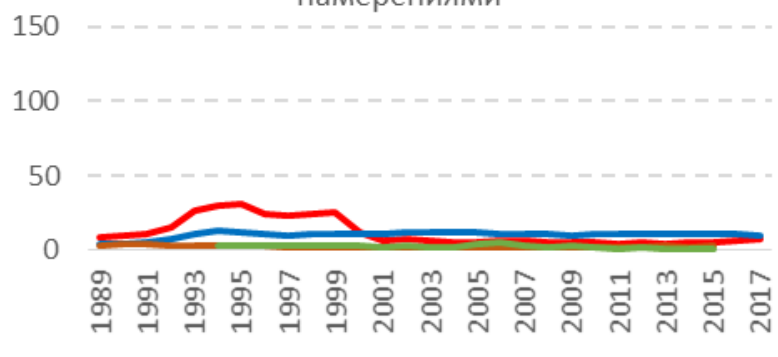
—Швеция — Эстония

Рисунок 13. Стандартизованный коэффициент смертности от внешних причин смерти, в Москве, России, Эстонии и Швеции, 1989-2017, на 100 тыс. населения 


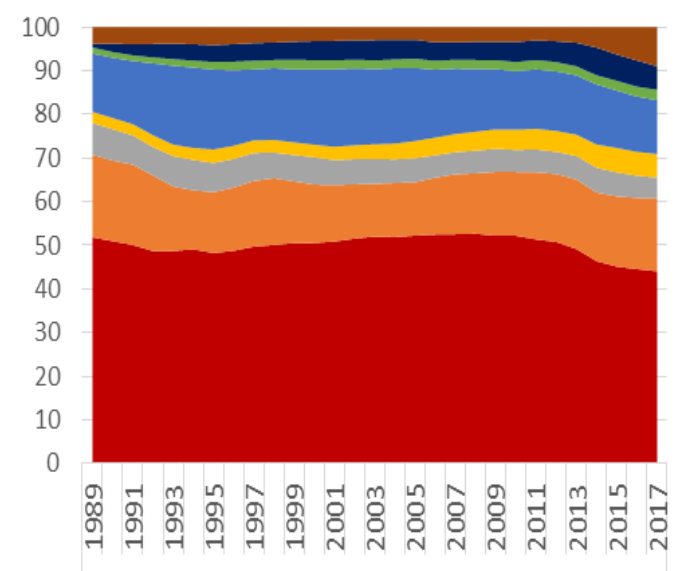

Россия без Москвы

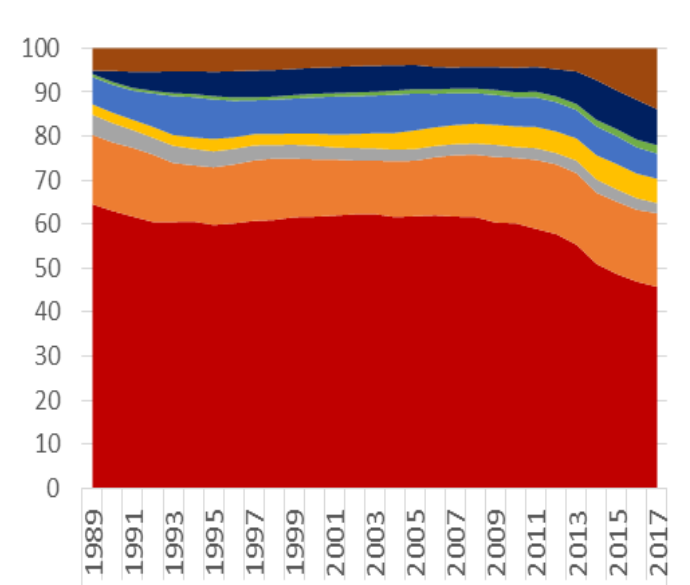

Россия без Москвы

-Прочие

Болезни органов пищеварения

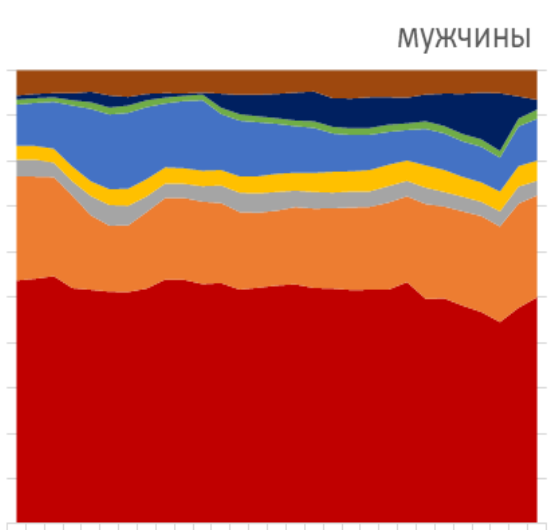

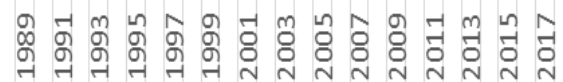

Москва

женщины

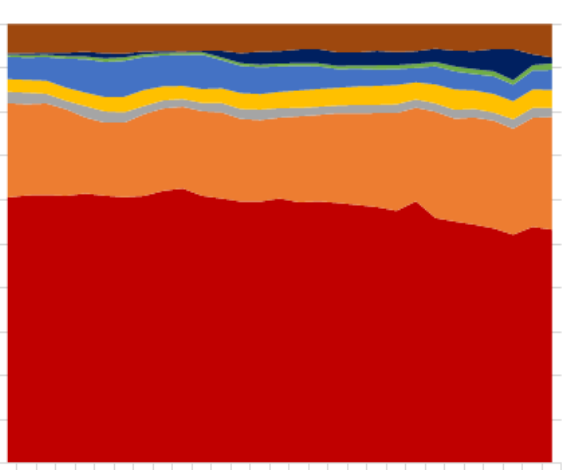

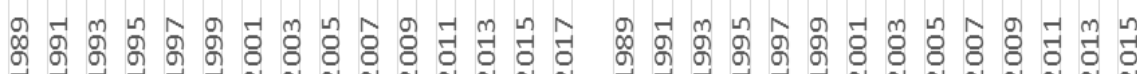

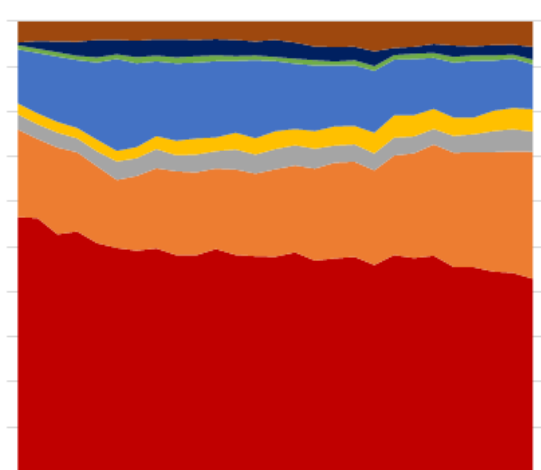

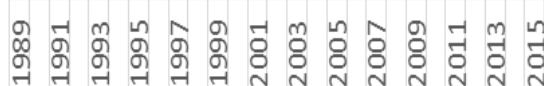

Эстония

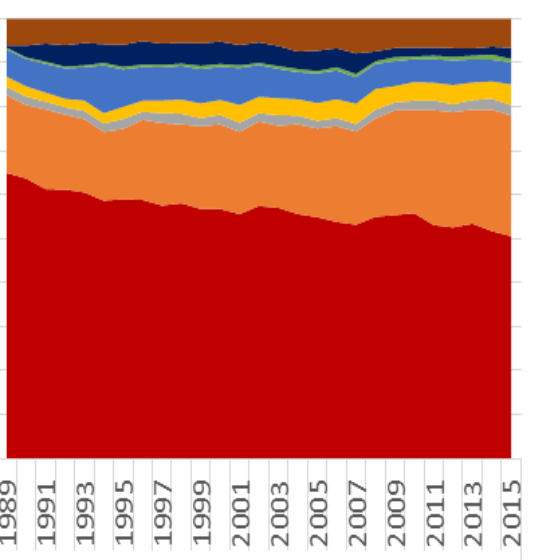

Эстония

- Инфекционные и паразитарные болезни - Новообразования

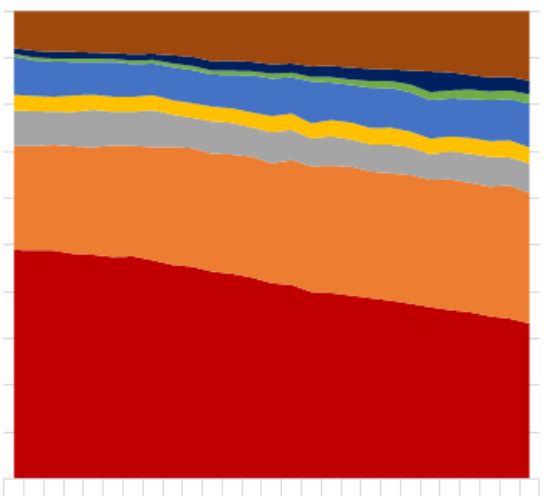

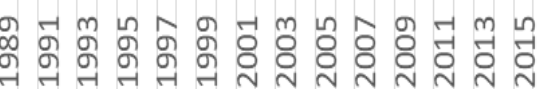

Швеция

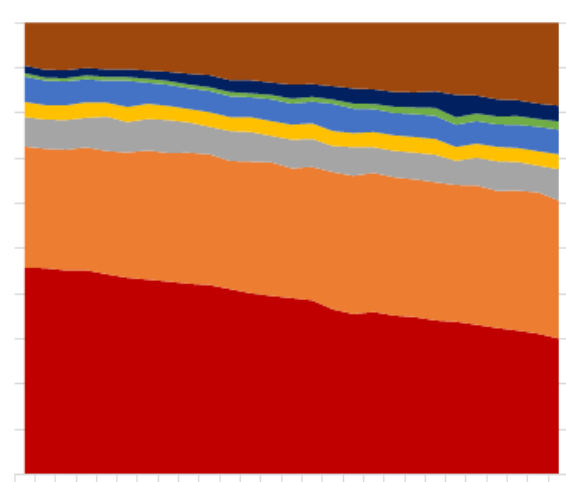

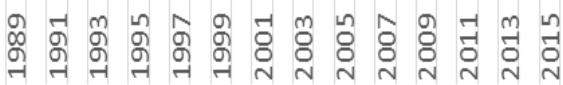

Внешние причины смерти

- Болезни системы кровообращения

Рисунок 14. Структура стандартизованного коэффициента смертности по причинам смерти в Москве, России, Эстонии и Швеции, 1989-2017, \% 
Таблица 4. Структура стандартизованного коэффициента смертности по причинам смерти, 1970-2017, \%

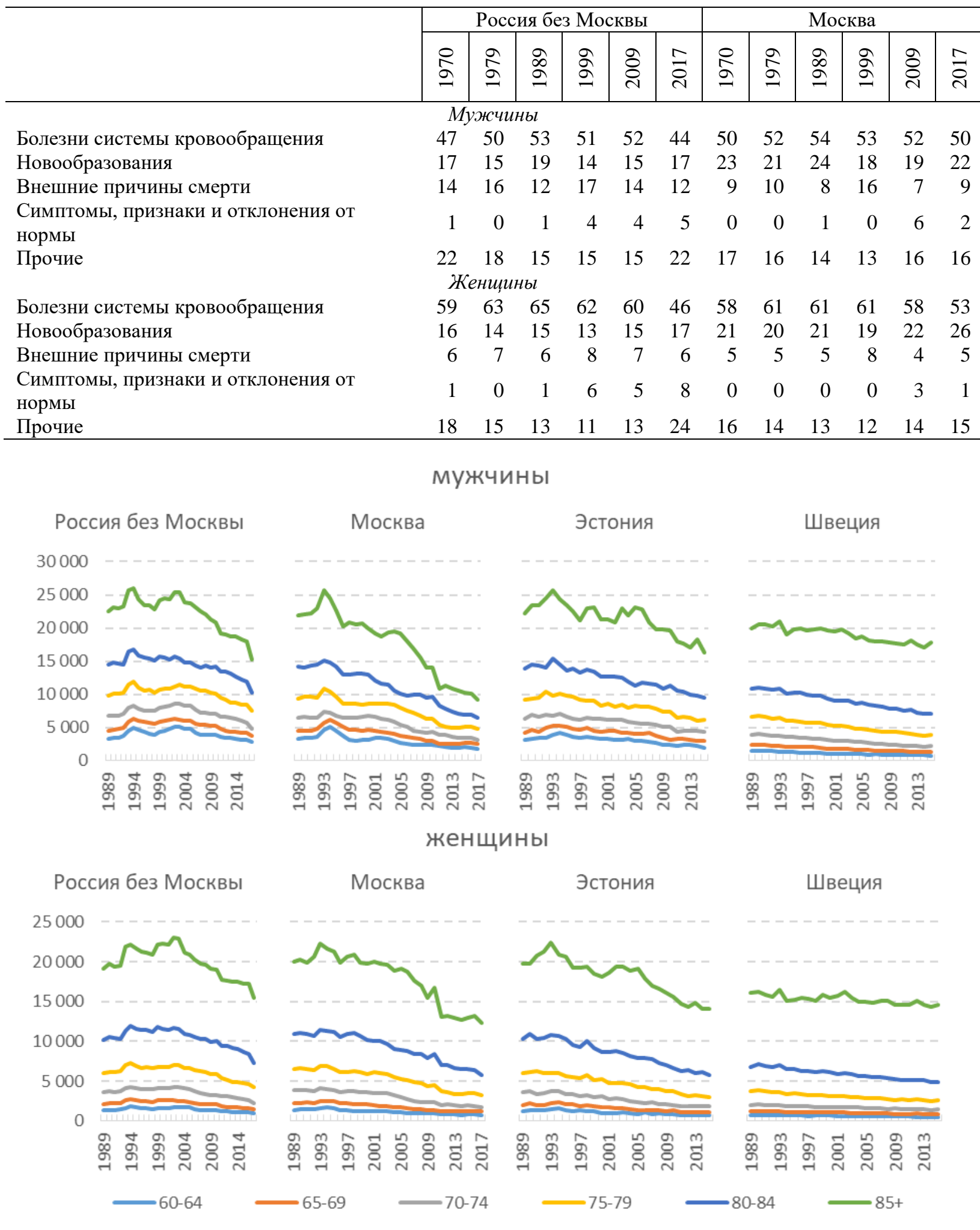

Рисунок 15. Возрастные коэффициенты смертности в возрастах старше 60 лет от болезней системы кровообращения, на 100 тыс. населения

Динамика возрастных коэффициентов смертности от болезней системы кровообращения (рисунок 15) показывает, что в течение последнего периода роста 
продолжительности жизни быстро снижался уровень смертности в самых старших возрастных группах (старше 80 лет). В Москве подобная динамика наблюдается с 1993 г., к 2017 г. смертность от БСК среди мужчин в Москве была ниже, чем в Швеции, а в России - на уровне Швеции. Вместе с тем смертность мужчин в более молодых возрастах снижалась медленнее и остается на более высоком уровне, чем в Швеции.

Что касается динамики возрастных коэффициентов смертности от новообразований, то следует отметить заметную тенденцию к снижению показателей в старших возрастных группах в Москве, не характерную для других территорий. При этом смертность в большинстве старших возрастных групп среди женщин в Москве остается выше, чем в России. Также заметно резкое снижение показателя в возрастах старше 80 лет в 1994 1995 гг. с последующим его восстановлением (рисунок 16).

мужчины

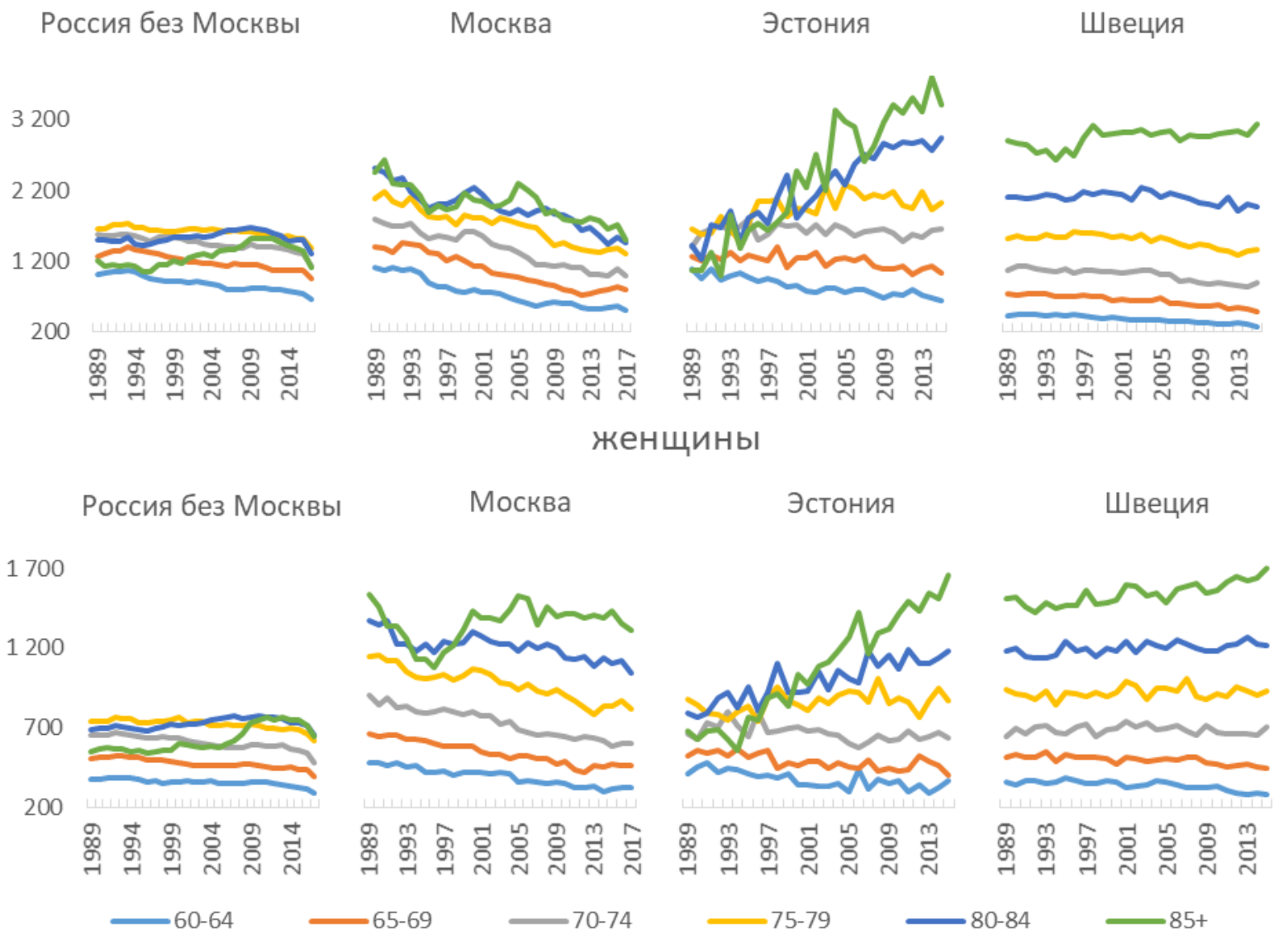

Рисунок 16. Возрастные коэффициенты смертности в возрастах старше 60 лет от новообразований, на 100 тыс. населения

\section{ПРИЧИНЫ СМЕРТИ В СТРУКТУРЕ ДИНАМИКИ И РАЗЛИЧИЙ В ПРОДОЛЖИТЕЛЬНОСТИ ЖИЗНИ}

Как было показано ранее, снижение смертности в средних и старших возрастных группах в Москве вносит больший вклад в рост продолжительности жизни, чем в России, а негативные изменения в смертности в 1998-2003 гг. проявлялись менее существенно. 
Рассмотрим, какой вклад внесли различные группы причин смерти в разницу продолжительности жизни между Москвой и Россией. Ранее мы показали (рисунок 2), что эта разница непрерывно росла с середины 1990-х годов, когда она была близка к нулю, до середины 2000-х, после чего она сохранялась приблизительно на одном и том же уровне.

Однако за это время произошло изменение возрастных компонент этих различий, а именно их смещение из средних в старшие возрастные группы (рисунок 17). К 2017 г. существенную роль в дифференциации между Москвой и Россией продолжают играть различия в смертности в трудоспособных возрастах, однако вклад возрастных групп старше 60 лет увеличивается для отдельных возрастов в несколько раз, а максимальные значения вкладов в разницу в ОПЖ смещаются с 40-60 лет на 60-75 лет (для мужчин).

В 1994 г. разница в продолжительности жизни между Москвой и Россией сохранялась на минимальном уровне и была обусловлена среди мужчин главным образом более низкой смертностью в Москве от внешних причин смерти в молодых возрастах, что при этом сопровождалось более высокой смертностью от болезней системы кровообращения и прочих причин смерти в трудоспособном возрасте. Среди женщин наблюдается иной паттерн различий: основная часть разницы приходится на возраст 50-80 лет, при этом более низкая смертность от болезней системы кровообращения, внешних причин (до 65 лет) и не установленных причин смерти (после 75 лет) отчасти компенсируется более высокой смертностью от новообразований. В возрасте старше 80 лет более низкая смертность от неустановленных причин смерти компенсируется также более высокой смертностью от новообразований и болезней системы кровообращения (рисунок 17).

Возрастной профиль различий в ожидаемой продолжительности жизни между Москвой и Россией в 1998 и 2005 г. похож. Различия среди мужчин обусловлены более низкой смертностью от внешних причин смерти в молодых и трудоспособных возрастах, а с 40 лет становится заметен вклад болезней системы кровообращения, роль которых выросла за 1998-2005 гг. (с 21 до 40\% всех различий). Среди женщин разница в смертности от болезней системы кровообращения имеет больший вес: 42 и 59\% в 1998 и 2005 г. соответственно, также в Москве сохраняется более низкая смертность от неустановленных причин смерти, которая компенсируется более высокой смертностью от новообразований, а в возрасте старше 80 лет - от болезней системы кровообращения.

К 2017 г., наряду с тем, что разница в продолжительности жизни все больше объяснялась различиями в смертности в старших возрастах, среди мужчин $10 \%$ всей разницы в ОПЖ приходится на класс «Симптомы, признаки и отклонения от нормы» в возрасте старше 85 лет, 7\% - на прочие причины смертности в данной возрастной группе, а 4\% - на болезни системы кровообращения, небольшой негативный для Москвы вклад вносит смертность от новообразований. Для женщин по-прежнему характерна более низкая смертность от неустановленных причин смерти и более высокая - от БСК и новообразований. 
мужчины

1994

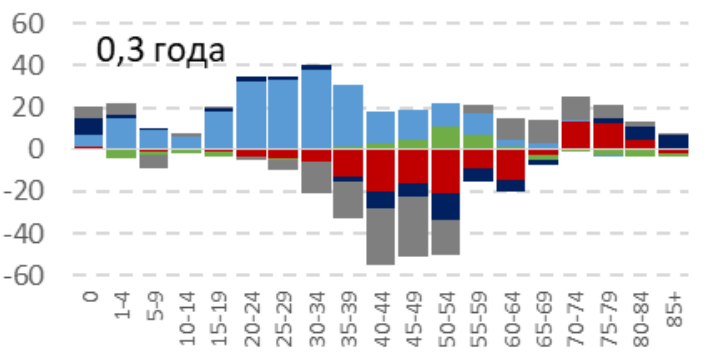

1998

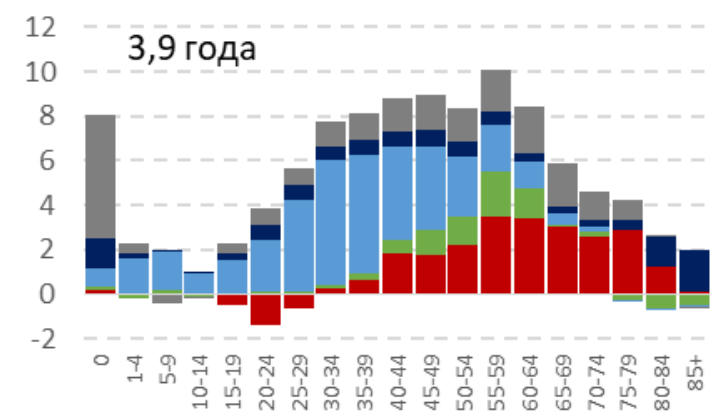

2005

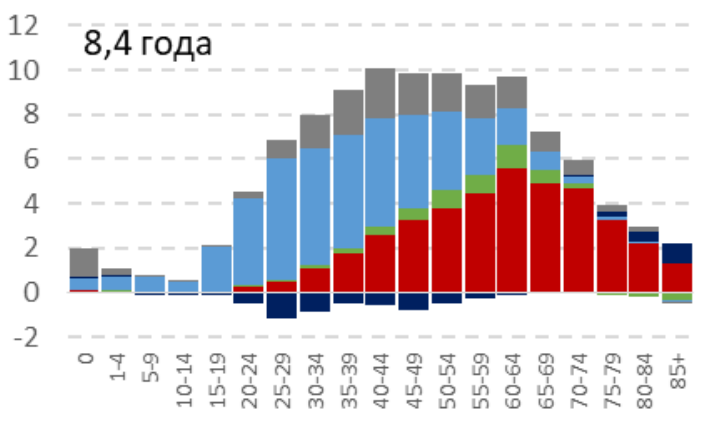

2017

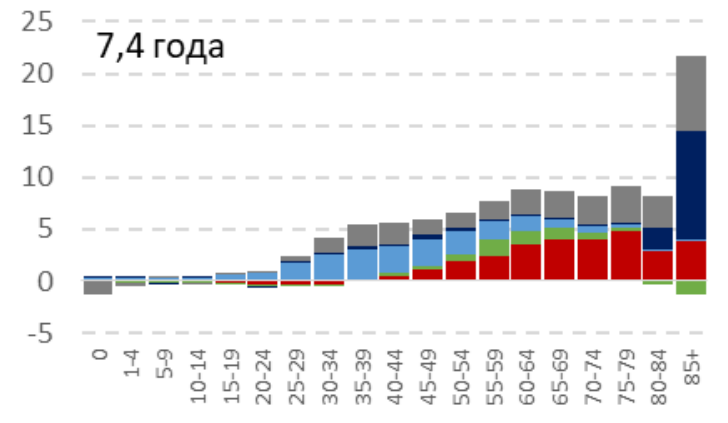

П Прочие

- Внешние причины смерти

- Болезни системы кровообращения женщины

1994

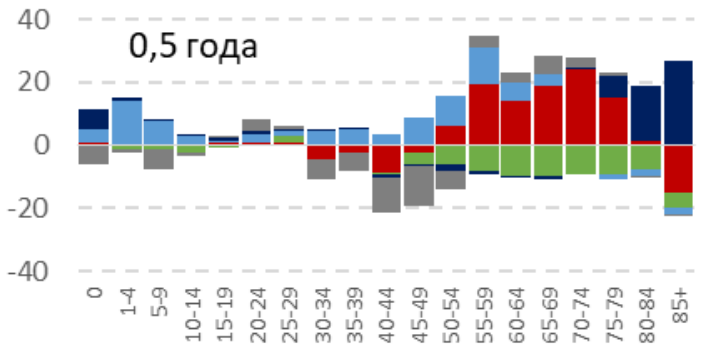

1998

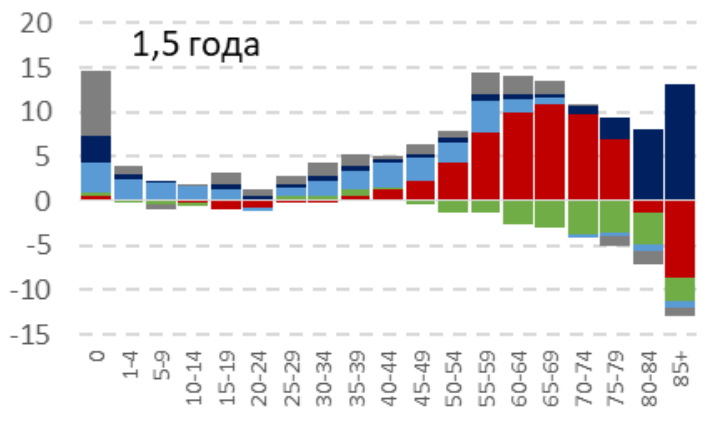

2005

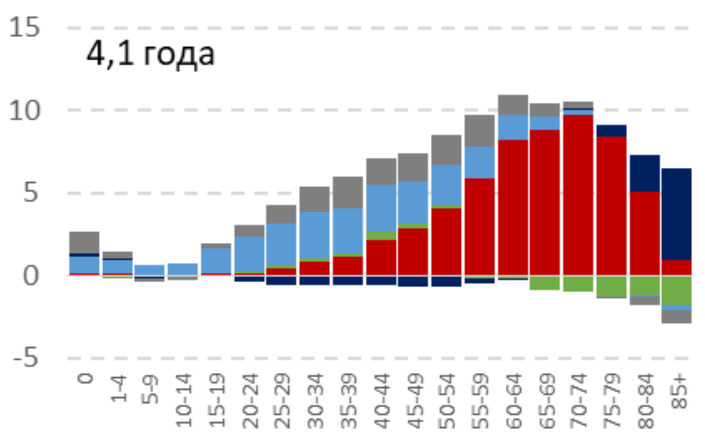

2017

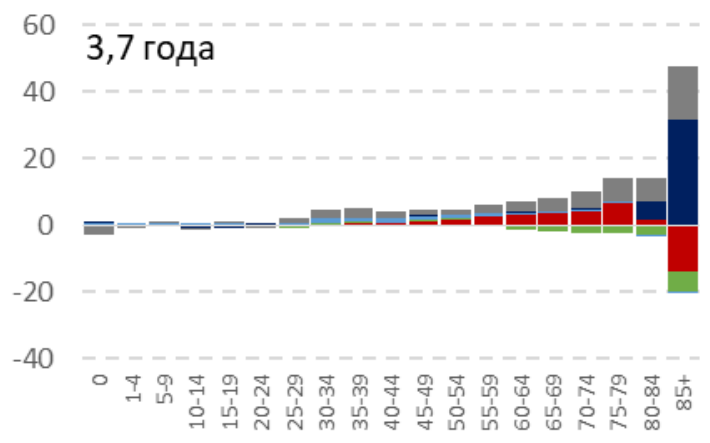

Симптомы, признаки и отклонения от нормы - Новообразования

\section{Рисунок 17. Декомпозиция разницы в ожидаемой продолжительности жизни между} Москвой и Россией, \% 


\section{ВОЗРАСТНЫЕ ОСОБЕННОСТИ СМЕРТНОСТИ ОТ ОСНОВНЫХ И НЕУСТАНОВЛЕННЫХ ПРИЧИН}

\section{Возрастной профиль смертности от основных причин смерти}

Сравнение возрастных профилей смертности от БСК показывает более молодую модель смертности в России и Москве, чем в других странах. Наряду с более высокими показателями смертности в возрасте до 80 лет, в возрасте старше 80 лет показатели смертности в Москве среди мужчин ниже, чем в Швеции. По уровню смертности в средних возрастах Москва занимает промежуточное положение между Россией и странами Запада и в большей степени близка к странам Прибалтики (рисунок 18).

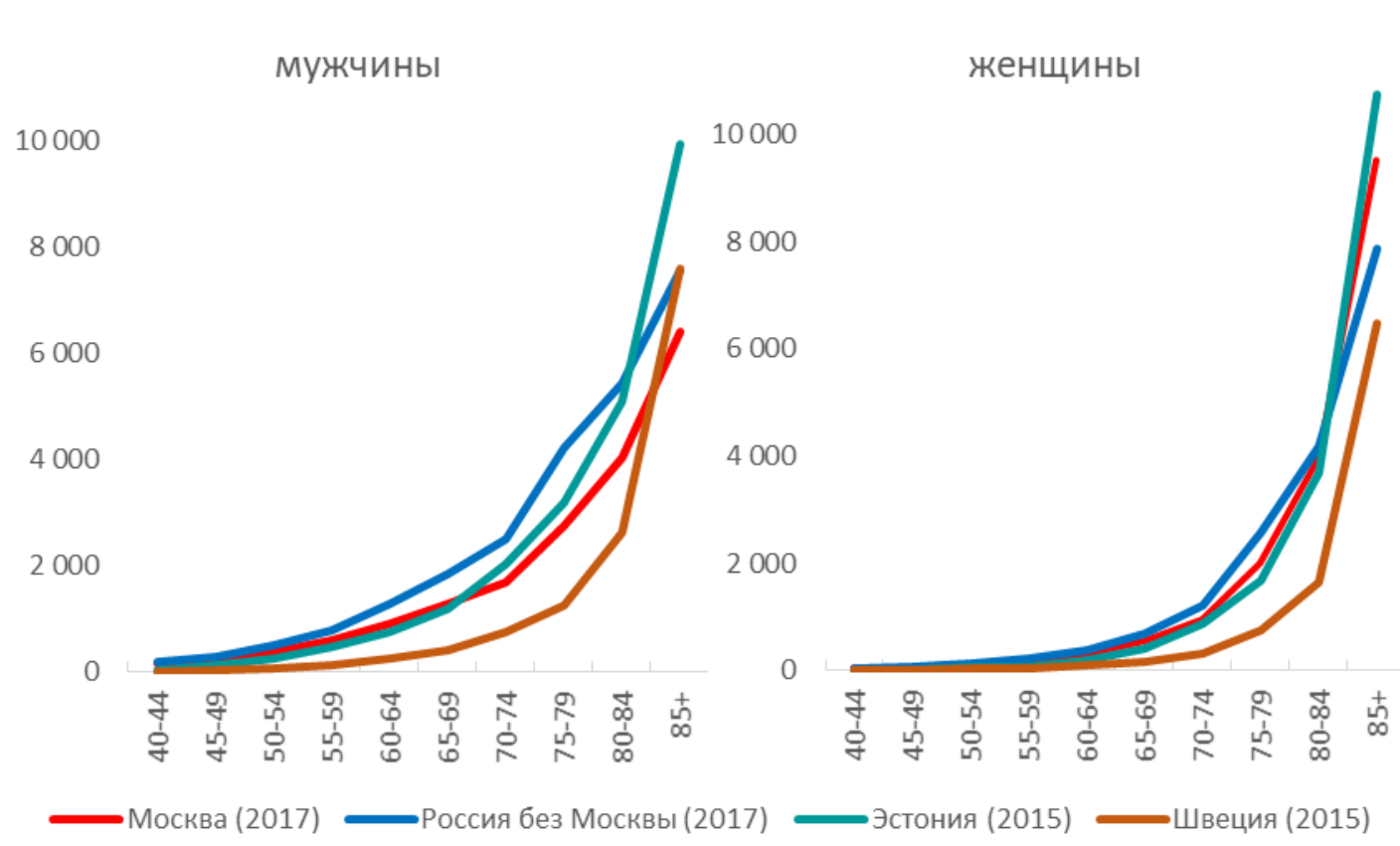

Рисунок 18. Возрастной профиль смертности от болезней системы кровообращения в Москве, России, Эстонии и Швеции, на 100 тыс. чел.

Возрастной профиль смертности от новообразований в России заметно отличается от зарубежных стран [Shkolnikov et al. 1999; Данилова 2015]. При том что в европейских странах коэффициент смертности от новообразований с возрастом интенсивно увеличивается, в России этот показатель почти не изменяется или даже снижается после 80 лет. В раннем исследовании смертности от рака в России и на Украине было показано, что, хотя эта особенность российской смертности от рака отчасти объясняется колебаниями распространенности курения в мужских когортах, в основном это связано с особенностями медицинской диагностики и регистрации причин смерти [Shkolnikov et al. 1999].

Эта особенность характерна и для Москвы: при более высокой смертности от новообразований в возрасте до 75-80 лет по сравнению с европейскими странами в более старшем возрасте показатели заметно ниже, чем в Швеции и Эстонии (среди мужчин в 2 раза). Однако в Москве существуют и заметные отличия от российской возрастной модели смертности от новообразований: так, в России в возрасте старше 70 лет смертность от новообразований находится на стабильном уровне среди женщин и снижается среди 
мужчин, тогда как в Москве, в особенности среди женщин, с возрастом более заметна тенденция к росту смертности от новообразований (рисунок 19).

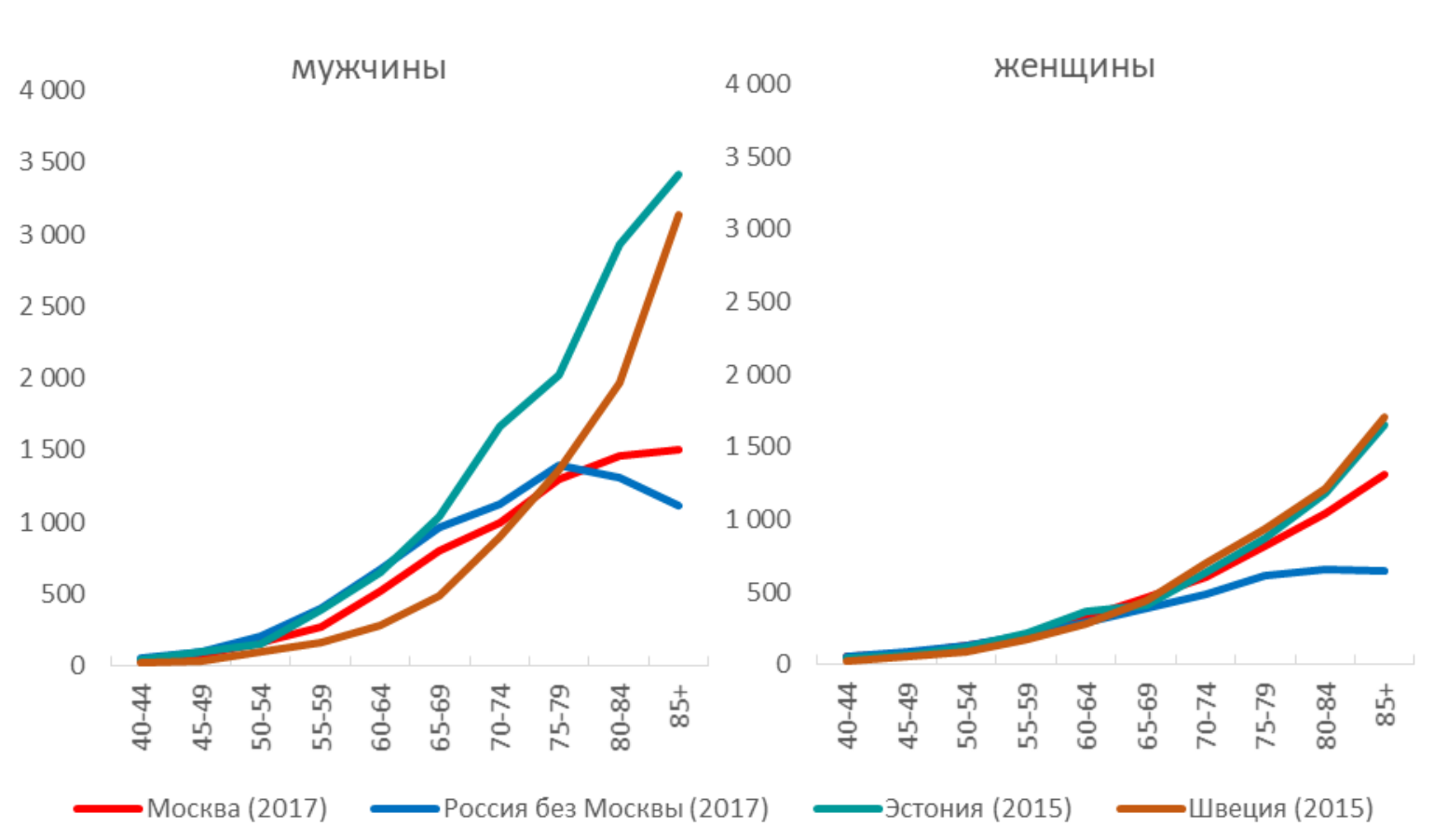

Рисунок 19. Возрастной профиль смертности от новообразований в Москве, России, Эстонии и Швеции, на 100 тыс. чел.

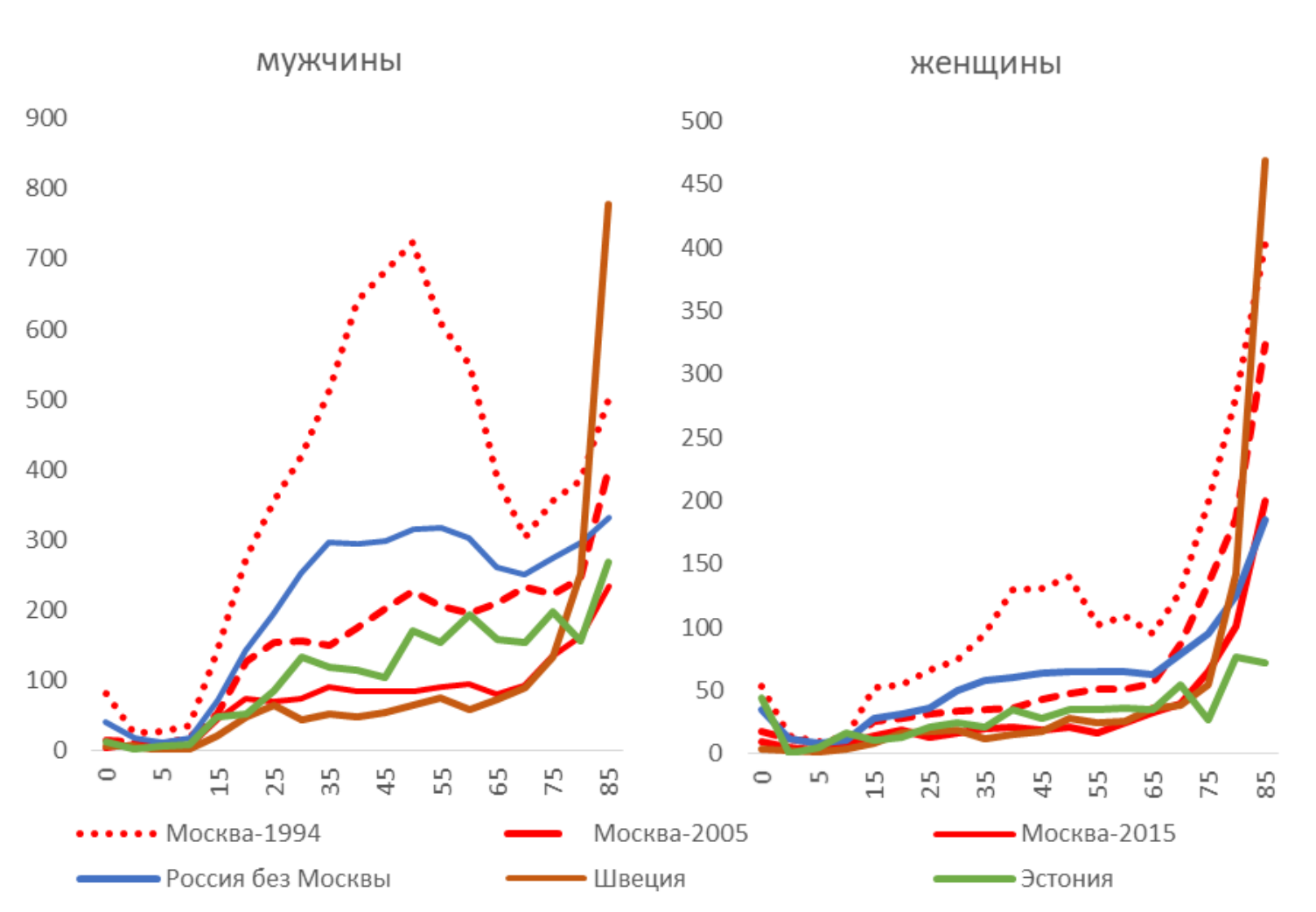

Рисунок 20. Возрастной профиль смертности от внешних причин смерти в Москве, России, Эстонии и Швеции, 2015, на 100 тыс. чел. 
Уровень смертности от внешних причин смерти в Москве к 2015 г. снизился во всех возрастах и особенно в трудоспособном возрасте, в результате чего смертность от внешних причин в Москве в большинстве возрастных групп сопоставима с уровнем, наблюдаемым в Швеции, за исключением возрастов старше 80 лет, в которых смертность в Москве в несколько раз ниже (рисунок 20).

\section{Неустановленные причины смерти}

Класс «Симптомы, признаки и отклонения от нормы» состоит из нескольких рубрик неопределённых причин смерти [Андреев 2016] и причины «Старость» (код по МКБ-10 R54). Данная причина смерти также относится к неточно обозначенным состояниям и не может быть выбрана при наличии любого состояния, классифицированного в других рубриках ${ }^{2}$, критериями использования этого кода являются, в частности, возраст старше 80 лет и отсутствие указаний на хронические заболевания. Практика использования данного кода сильно отличается среди регионов России: так, в России в целом на данную причину приходится до 15\% всех умерших в возрасте старше 80 лет [Данилова 2015], в Москве по данным Росстата за 2016-2017 гг. случаев смерти от старости не отмечалось.

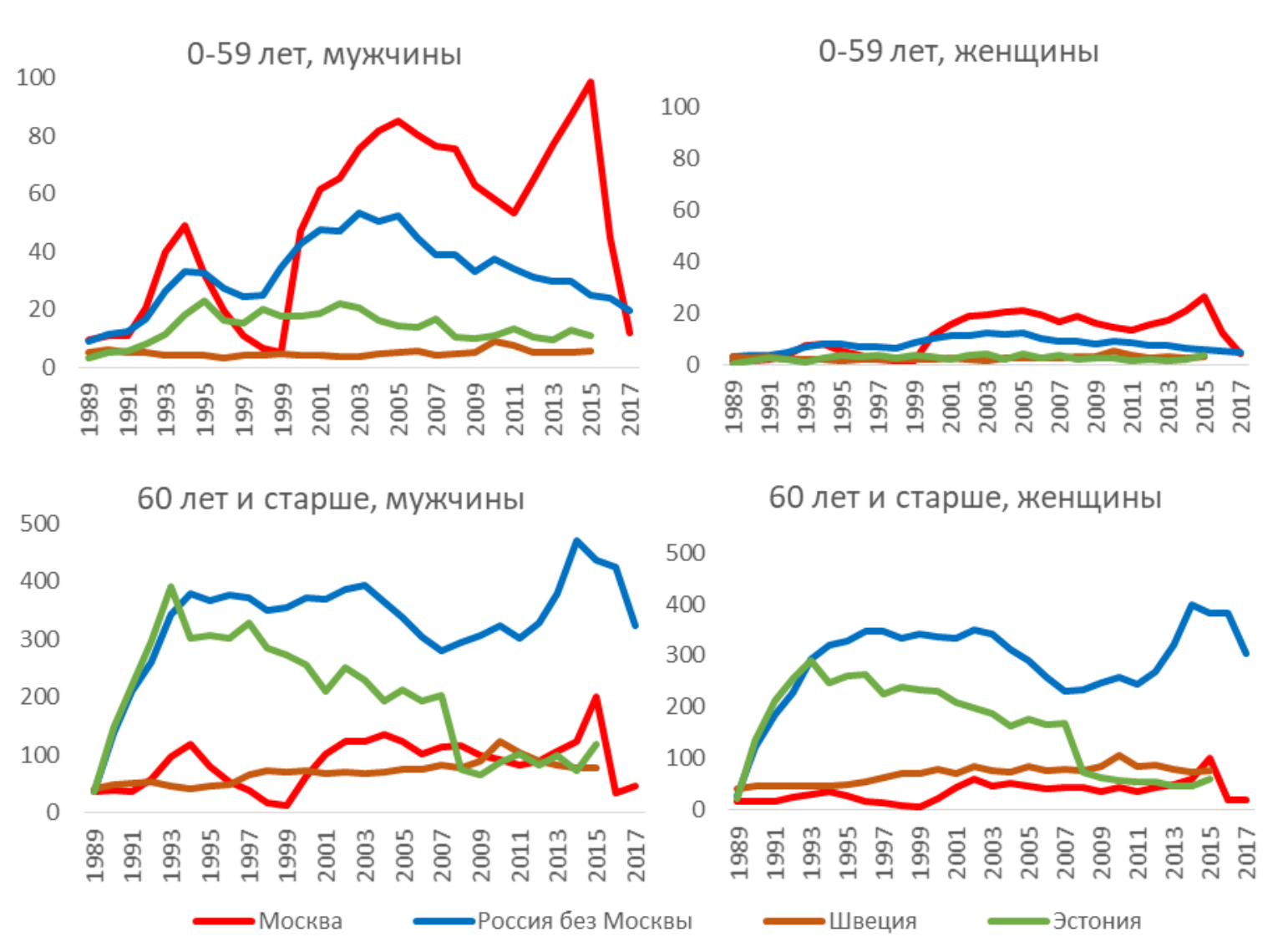

Рисунок 21. Стандартизованный коэффициент смертности от класса "Симптомы, признаки и отклонения от нормы" в Москве, России, Эстонии и Швеции, 1989-2017, на 100 тыс. чел.

\footnotetext{
2 Письмо Министерства здравоохранения Российской Федерации от 19.12.2014 №13 2/1750.
} 
Вместе с тем при отсутствии умерших от «Старости» Москва с начала 2000-х годов характеризовалась высокой долей смертей с причиной из рубрики «Другие виды внезапной смерти по неизвестной причине, смерть без свидетелей» (код по МБК-10 - R96-R99). СКС от класса «Симптомы, признаки и отклонения от нормы» в целом в Москве был ниже, чем в России, а в 2016-2017 гг. достиг минимального уровня, наблюдавшегося в 1990-е годы. При этом СКС от неустановленных причин в возрасте старше 60 лет в несколько раз ниже по сравнению с Россией, а в возрасте до 60 лет с начала 2000-х годов по 2016 г. - в 1,5-2 раза выше (рисунок 21). Как указывает Е. Андреев, вероятнее всего выбор в качестве причины смерти неустановленных причин связан с отсутствием стимулов к уточнению причины смерти после выдачи предварительного свидетельства о смерти [Андреев 2016], кроме того, сбои могут наступать на этапе обработки данных в органах статистики.

Особенности структуры смертности от класса «Симптомы, признаки и отклонения от нормы» заметны и по возрастному распределению умерших с неустановленными причинами смерти. Так, в Москве основная часть таких смертей приходится на население в молодом и трудоспособном возрасте, а возрастной коэффициент смертности стабилизируется на достигнутом уровне после 40 лет. В России коэффициент резко возрастает после 80 лет. В 2016-2017 гг. доля смертей, в случае которых причина смерти не была установлена, в Москве вдруг резко сократилась во всех возрастных группах (рисунок 22).

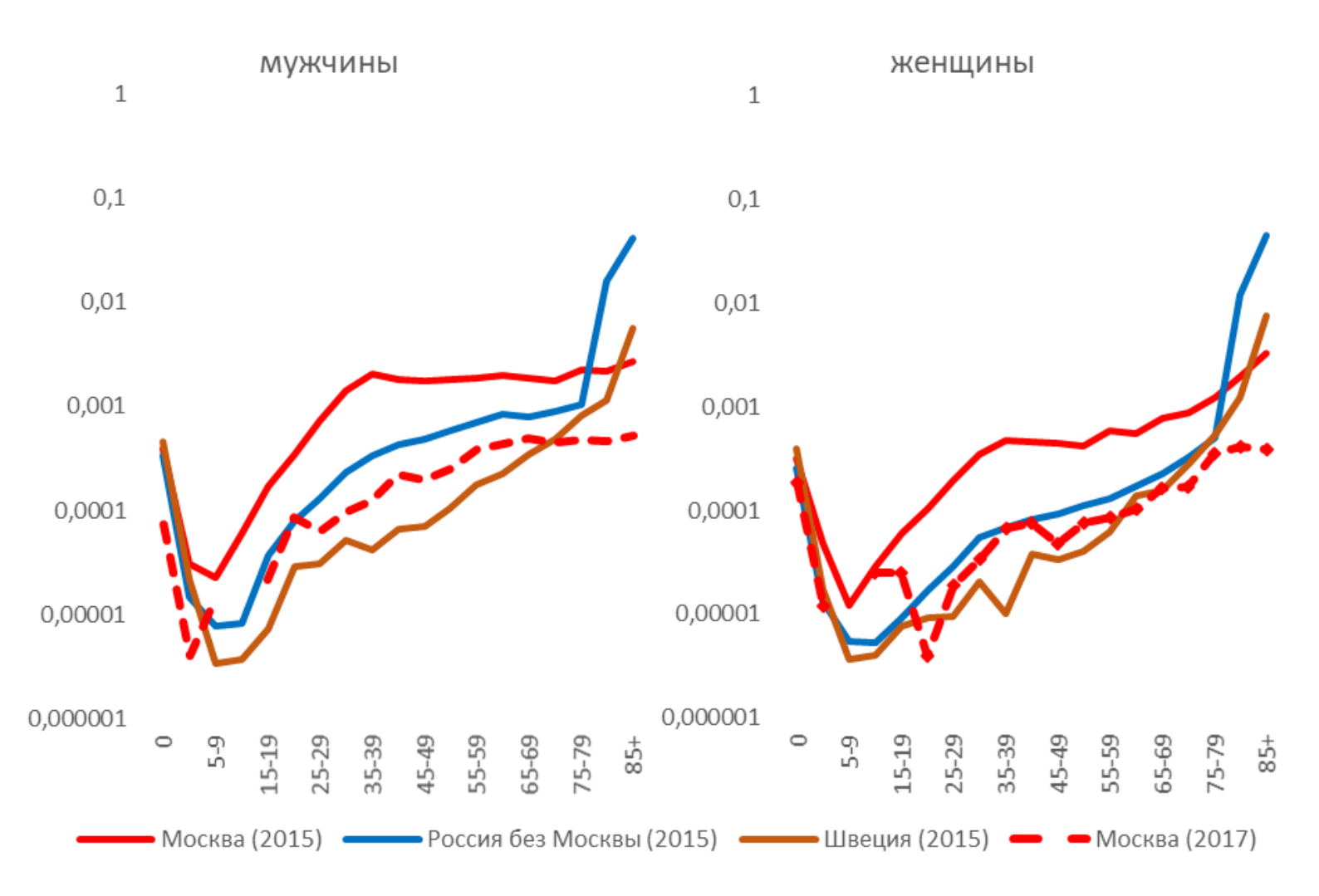

Рисунок 22. Возрастной профиль смертности от класса «Симптомы, признаки и отклонения от нормы» в Москве, России, Эстонии и Швеции, на 100 тыс. чел.

Примечание: Данные показаны в логарифмической шкале. 
Таблица 5. Число зарегистрированных в Москве умерших от класса «Симптомы, признаки и отклонения от нормы» и других основных классов причин смерти, 2015 и 2017, чел.

\begin{tabular}{|c|c|c|c|c|c|c|}
\hline & \multicolumn{3}{|c|}{ Мужчины } & \multicolumn{3}{|c|}{ Женщины } \\
\hline & 2015 & 2017 & $\begin{array}{c}\text { прирост } 2017 \\
\text { к 2015, чел. }\end{array}$ & 2015 & 2017 & $\begin{array}{r}\text { прирост } 2017 \\
\text { к 2015, чел. }\end{array}$ \\
\hline & \multicolumn{6}{|c|}{ Всего умерших } \\
\hline $0-14$ & 694 & 661 & -33 & 544 & 523 & -21 \\
\hline $15-29$ & 1568 & 1312 & -256 & 542 & 454 & -88 \\
\hline $30-44$ & 6307 & 5272 & -1035 & 2154 & 2052 & -102 \\
\hline $45-59$ & 11750 & 10706 & -1044 & 5335 & 5020 & -315 \\
\hline $60-74$ & 17760 & 17648 & -112 & 12815 & 12703 & -112 \\
\hline 75 и старше & 19296 & 19561 & 265 & 43075 & 42564 & -511 \\
\hline Неизвестен & 47 & 307 & 260 & 4 & 86 & 82 \\
\hline \multirow[t]{2}{*}{ Всего } & 57422 & 55467 & -1955 & 64469 & 63402 & -1067 \\
\hline & \multicolumn{6}{|c|}{ Симптомы, признаки и отклонения от нормы } \\
\hline $0-14$ & 57 & 10 & -47 & 43 & 21 & -22 \\
\hline $15-29$ & 525 & 54 & -471 & 156 & 16 & -140 \\
\hline $30-44$ & 2599 & 207 & -2392 & 662 & 92 & -570 \\
\hline $45-59$ & 2242 & 330 & -1912 & 689 & 97 & -592 \\
\hline $60-74$ & 1333 & 328 & -1005 & 728 & 149 & -579 \\
\hline 75 и старше & 676 & 143 & -533 & 1238 & 241 & -997 \\
\hline Неизвестен & 24 & 69 & 45 & 2 & 20 & 18 \\
\hline \multirow[t]{2}{*}{ Всего } & 7456 & 1141 & -6315 & 3518 & 636 & -2882 \\
\hline & \multicolumn{6}{|c|}{ Болезни системы кровообращения } \\
\hline $0-14$ & 3 & 1 & -2 & 0 & 0 & 0 \\
\hline $15-29$ & 57 & 245 & 188 & 26 & 74 & 48 \\
\hline $30-44$ & 780 & 1664 & 884 & 216 & 448 & 232 \\
\hline $45-59$ & 4244 & 4955 & 711 & 1327 & 1498 & 171 \\
\hline $60-74$ & 8625 & 8998 & 373 & 5818 & 5875 & 57 \\
\hline 75 и старше & 12016 & 12392 & 376 & 31167 & 30536 & -631 \\
\hline Неизвестен & 4 & 100 & 96 & 0 & 34 & 34 \\
\hline \multirow[t]{2}{*}{ Всего } & 25729 & 28355 & 2626 & 38554 & 38465 & -89 \\
\hline & \multicolumn{6}{|c|}{ Новообразования } \\
\hline $0-14$ & 49 & 61 & 12 & 44 & 59 & 15 \\
\hline $15-29$ & 92 & 93 & 1 & 61 & 65 & 4 \\
\hline $30-44$ & 342 & 350 & 8 & 431 & 509 & 78 \\
\hline $45-59$ & 2247 & 2135 & -112 & 2061 & 2011 & -50 \\
\hline $60-74$ & 5087 & 5390 & 303 & 4485 & 4797 & 312 \\
\hline 75 и старше & 4211 & 4371 & 160 & 6761 & 6718 & -43 \\
\hline Неизвестен & 1 & 4 & 3 & 0 & 1 & 1 \\
\hline \multirow[t]{2}{*}{ Всего } & 12029 & 12404 & 375 & 13843 & 14160 & 317 \\
\hline & \multicolumn{6}{|c|}{ Внешние причины } \\
\hline $0-14$ & 65 & 67 & 2 & 44 & 46 & 2 \\
\hline $15-29$ & 713 & 711 & -2 & 165 & 174 & 9 \\
\hline $30-44$ & 1243 & 1567 & 324 & 298 & 349 & 51 \\
\hline $45-59$ & 1088 & 1176 & 88 & 270 & 359 & 89 \\
\hline $60-74$ & 629 & 729 & 100 & 316 & 326 & 10 \\
\hline 75 и старше & 473 & 495 & 22 & 698 & 782 & 84 \\
\hline Неизвестен & 10 & 87 & 77 & 1 & 17 & 16 \\
\hline Всего & 4221 & 4832 & 611 & 1792 & 2053 & 261 \\
\hline
\end{tabular}

К 2017 г. по сравнению с 2015 г. абсолютное число умерших с не установленными причинами смерти снизилось с 10,97 тыс. до 1,78 тыс. (на 84\%) - на 6,3 тыс. среди мужчин и на 2,9 тыс. среди женщин (всего на 9,2 тыс.). Подобное снижение характерно для всех возрастных групп, максимальный вклад в общее снижение внесла возрастная группа 30 44 года (32\% общей разницы между 2015 и 2017 г.), 45-59 лет (27\%), по 17 \% приходится 
на возраст 60-74 года и 75 лет и старше. Общее число умерших от всех причин в 2017 г. по сравнению с 2015 г. снизилось на 1,95 тыс. среди мужчин и 1,07 тыс. среди женщин (всего на 3 тыс.). При этом отмечается рост числа умерших от основных классов причин смерти, например, от болезней системы кровообращения - на 2,5 тыс., от новообразований - на 692 человека (таблица 5). Таким образом, за 2016-2017 гг. наряду с резким снижением количества смертей с неустановленными причинам смерти и снижением общего числа умерших происходит рост числа умерших от определенных причин смерти, что является следствием изменения практики учета медицинских свидетельств о смерти, выданных взамен предварительных.

\section{ЗАКЛЮЧЕНИЕ}

Москва не только является регионом с наиболее высокой продолжительностью жизни в России, но и регионом, определяющим рост межрегионального неравенства в России в период текущего роста продолжительности жизни [Timonin et al. 2017]. Основы опережения Москвы по продолжительности жизни над остальными регионами России были заложены в период с середины 1990-х до начала 2000-х годов.

Продолжительность жизни в Москве до 1990-х годов отличалась от среднероссийского уровня не так значительно, как в современный период. Среди мужчин показатель был на 2,3-2,5 года выше, чем по России в среднем, среди женщин различие составляло менее полугода. С похожими показателями Москва подошла к началу 1990-х годов. Снижение ОПЖ в начале 1990-х годов в Москве было выше, чем в менее благополучных регионах. Таким образом, к 1994 г. у столицы не было какого-либо преимущества в продолжительности жизни по сравнению с остальной страной. Однако с 1996 г. компенсационный рост ОПЖ в Москве происходил более высокими темпами, чем в России. Также Москва избежала очередного роста смертности в конце 1990-х годов, а начало стабильного роста показателя началось в ней на несколько лет раньше, чем в остальной России. В результате сформировался разрыв в продолжительности жизни между Москвой и Россией, который остается практически на том же уровне уже более 10 лет, т. е. весь период устойчивого роста ОПЖ.

Эти различия среди мужчин с конца 1990-х были обусловлены более низкой смертностью от внешних причин смерти в молодых трудоспособных возрастах и от болезней системы кровообращения в более старших возрастах. Среди женщин основной вклад вносили болезни системы кровообращения, а в наиболее старших возрастах заметны структурные различия с более низкой смертностью от неустановленных причин и более высокой - от болезней системы кровообращения и новообразований. При этом все большая часть различий в ОПЖ между Москвой и Россией приходится на все более пожилой возраст.

Москва, наряду с другими мегаполисами, характеризуется более высоким уровнем экономического развития. Уровень ВВП на душу населения в Москве в 2010 г. был сопоставим с Австрией, Канадой, Ирландией и Нидерландами. Тем не менее уровень продолжительности жизни в Москве все же оказался ниже, чем следовало бы ожидать на 
основе уровня ВВП, несмотря на то, что Москва занимает ведущее место среди регионов России как по уровню ОПЖ, так и по ВВП на душу населения [Андреев, Школьников 2018].

Одной из наиболее важных характеристик населения, влияющих на демографические процессы, является уровень образования. Известно, что смертность достоверно ниже среди наиболее образованных групп населения [Shkolnikov et al. 1998b]. Образовательная структура Москвы заметно отличается от населения России в целом. Во всех возрастных группах в Москве доля населения с высшим образованием в 1,5-2 раза выше, чем в России, а среди пожилых людей (в возрасте старше 75 лет) - в 2,3-2,4 раза 3 .

Предыдущие исследования смертности в зависимости от уровня образования показали, что большая часть положительных изменений в смертности в России связана с изменением структуры населения, а именно с ростом доли высокообразованных людей и снижением смертности в этой группе [Shkolnikov et al. 2006; Харькова, Никитина, Андреев 2017], а анализ индивидуальных данных показал, что дополнительный год обучения связан с 5\%-ным меньшим риском смертности от всех причин и сердечно-сосудистых заболеваний [Todd, Shkolnikov, Goldman 2016]. Более образованное население, что закономерно, исходя из статуса столицы, наряду с высоким миграционным приростом является одним из основных факторов, определяющих особенности демографических процессов в Москве.

Немаловажное значение, с точки зрения уровня смертности, имеют ресурсы и качество здравоохранения. Число врачей на душу населения в середине 2000-х годов в Москве было в 1,5 раза выше (72,7 врача на 10 тыс. населения в 2005 г.), чем в среднем по России, однако к 2016 г. этот показатель снизился и опережает среднероссийский на 19\% (для сравнения - в Санкт-Петербурге на $40 \%)^{4}$. В целом можно предположить, что, с точки зрения количественных показателей здравоохранения, концентрация ресурсов и территориальная доступность медицинской помощи позволяют достигать более высоких результатов при меньших вложениях и затратах на душу населения. Кроме того, наиболее важными, скорее всего, являются и качественные характеристики здравоохранения в Москве: оснащенность оборудованием, квалификация врачей, дополнительный вклад вносят в федеральные медицинские организации, более доступные для населения Москвы, чем для других регионов. В этой связи важно то, что в Москве находятся почти все ведущие федеральные медицинские научные и клинические центры. Конечно, эти центры принимают пациентов из всех регионов страны, но москвичи имеют более высокие шансы попасть в них на лечение.

По данным, скорректированным с учетом результатов переписи 2002 г., в период с середины 1990-х по начало 2000-х годов в Москве наблюдался интенсивный рост численности населения. Перепись 2002 г. показала в Москве проживает более 10 млн человек, что на 1,85 млн (на 22\%) больше, чем оценка по данным текущего учета. Основная часть миграционного прироста населения, учтенного по результатам переписи 2002 г., приходится на трудоспособный возраст. Именно население в трудоспособном возрасте

\footnotetext{
${ }^{3}$ По данным микропереписи 2015 г.

${ }^{4}$ Регионы России. Социально-экономические показатели - 2017 г. (2017). Федеральная служба государственной статистики. URL: http://www.gks.ru/bgd/regl/b17_14p/Main.htm (данные загружены 20.10.2018).
} 
внесло основной вклад в рост продолжительности жизни в Москве и некоторых других регионах в период ее неустойчивой динамики. Это может указывать на такие факторы динамики продолжительности жизни, как селективный эффект «здорового мигранта», на более благоприятные условия жизни в регионах, притягивающих мигрантов.

Отдельным фактором высокого уровня ожидаемой продолжительности жизни в Москве является качество данных о смертности и численности населения. Сомнения относительно правдоподобности уровня смертности в трудоспособных возрастах в период середины 2000-х годов ранее уже высказывались исследователями [Андреев, Кваша, Харькова 2006]. Как было упомянуто выше, на трудоспособный возраст приходится основной прирост численности населения Москвы в межпереписной период 1989-2002 гг., эта же группа определила динамику ОПЖ в Москве в период конца 1990-х - начала 2000-х годов. При этом в указанный период в России, помимо Москвы, было всего несколько регионов, в которых между 1998 и 2005 г. не произошло снижения продолжительности жизни. Это, в частности, Ханты-Мансийский, Ямало-Ненецкий автономные округа, Якутия, Калмыкия. Для этих регионов также характерна высокая миграция рабочей силы и лучшее экономическое положение. Однако трудоспособное население при его высокой миграционной подвижности - наиболее сложная для учета группа в привлекательных для миграции регионах. Это наводит на мысль, что динамика показателей смертности в трудоспособном возрасте может быть искажена вследствие неточной оценки численности этой возрастной группы. С другой стороны, нет существенных причин сомневаться в высокой миграции в Москву как в конце 1990-х - начале 2000-х годов, так и в настоящий период. Кроме того, динамика продолжительности жизни в трудоспособном возрасте в Москве носит вполне правдоподобный характер в отличие от продолжительности жизни пожилого населения.

Продолжительность жизни мужчин в возрасте 80 лет выше, чем в любой другой стране, а темпы прироста особенно резко увеличились после 2010 г. Это делает вопрос качества данных о смертности пожилого населения наиболее актуальным для Москвы. В отношении смертности этой группы в Москве было показано особенно значимое занижение смертности пожилых мужчин (в возрасте 80 лет и старше), что проявляется как в «кроссоверах» смертности, так и в неправдоподобном соотношении смертности в возрасте старше 80 лет и в более младших возрастных группах [Папанова и др. 2017]. По результатам оценки на основе этого соотношения ОПЖ мужчин в возрасте 80 лет для Москвы была скорректирована на 4 года - с 9,9 до 5,9 года. Степень этого завышения увеличивается с середины 2000-х годов, наряду с ростом ожидаемой продолжительности жизни. Особенно эти проблемы усугубляются после 2011 г., в этот период аналогичные тенденции наблюдаются в Москве также среди женщин. Подобные расхождения, вероятнее всего, являются следствием завышения численности населения в пожилом возрасте и характерны не только для Москвы, но и для большинства развитых стран, в частности для Германии [Thatcher, Kannisto, Andreev 2002; Jdanov, Scholz, Shkolnikov 2005].

По отношению к численности пожилого населения исследователи указывают его вероятное завышение по причине двойного учета, при этом отмечается, что значительная часть «переучтенного» пожилого населения приходится на Москву, а также на Московскую область, Санкт-Петербург и Ленинградскую область [Мкртчян 2012; Андреев 2012]. 
Расхождения в численности населения по данным переписей и по результатам текущего учета могут быть связаны с недоучетом миграции в межпереписной период и с недостатками при учете отдельных половозрастных групп при проведении переписи, в частности - с двойным счетом населения, завышением или округлением возраста респондентами. Первый фактор особенно актуален для Москвы в силу ее специфики как столицы и крупнейшей городской агломерации, привлекающей миграционные потоки.

По отношению к пожилому населению основным фактором завышения его численности при переписи называется, как правило, именно двойной учет, на который в Москве могла повлиять большая миграционная подвижность мужчин [Папанова и др. 2017]. Этот фактор может быть актуальным также для учета смертей, которые могут быть зарегистрированы в регионах фактического проживания умершего, учтенного переписью населения как проживающий в Москве.

Особенности смертности по причинам смерти в регионах России подвержены значительному влиянию региональных практик выбора первоначальной причины смерти [Danilova et al. 2016]. Качество данных о смертности по причинам смерти, в том числе на уровне регионов России, является отдельным исследовательским вопросом.

Отдельное внимание в рамках этого вопроса уделяется болезням системы кровообращения, смертность от которых в России исключительно высока по международным меркам. Однако направленные на установление качества кодирования причин смерти в России исследования показали не только отсутствие завышения смертности от болезней системы кровообращения, но также и высокую вероятность ее занижения в пожилых возрастах за счет отнесения к неустановленным причинам смерти. Тем не менее были найдены неточности в определении причины смерти внутри класса болезней системы кровообращения, а именно завышения количества смертей от атеросклеротической болезни сердца и занижение смертности от других болезней сердца [Shkolnikov, Meslé, Vallin 1996]. При этом наиболее правдоподобными оказались данные о смертности от таких причин смерти, как новообразования и внешние причины смерти, а наименее - от болезней органов дыхания и пищеварения.

Согласно результатам исследования [Danilova et al. 2016], наиболее несопоставимыми по регионам являются такие причины смерти, как отдельные причины внутри класса болезней системы кровообращения, неустановленные причины смерти, эндокринные заболевания, болезни нервной системы, психические заболевания. Наиболее сопоставимыми оказались транспортные несчастные случаи, новообразования, врожденные аномалии и состояния, возникающие в перинатальном периоде. Несмотря на то, что новообразования оказались в списке наиболее сопоставимых причин смерти, было также показано, что возрастной профиль смертности от новообразований в России существенно отличается от такового в других странах более низкой смертностью в старших возрастах, а снижение смертности от новообразований в России в 1990-е годы частично может быть обусловлено неполной регистрацией умерших от рака в возрасте старше 75 80 лет [Shkolnikov et al. 1999; Данилова 2015].

Особенности возрастного профиля смертности по причинам смерти в наиболее старших возрастных группах объясняются обменом между не установленными причинами, 
в том числе старостью, и установленными причинами смерти, в частности болезнями системы кровообращения. Для России была показана высокая обратная корреляция между этими группами причин: так, рост числа умерших от старости сопровождается снижением смертности от болезней системы кровообращения [Вишневский, Андреев, Тимонин 2016; Данилова 2015]. Подобные изменения в практике регистрации связываются с административными решениями: в 1989 г. при министре здравоохранения Е.И. Чазове были приняты указания, согласно которым умершим вне стационара в возрасте старше 80 лет при отсутствии подозрений на насильственную смерть и указаний на заболевания, которые могли стать причиной смерти, в медицинской документации без проведения патологоанатомического вскрытия в качестве причины смерти указывалась «Старость» [Shkolnikov, Meslé, Vallin 1996]. В результате этого с середины 1990-х до середины 2000-х годов смертность от данной причины в России находилась на стабильно высоком уровне и начала снижаться вместе с ростом продолжительности жизни. Однако с 2012 г. после принятия целевых показателей по снижению смертности от основных причин смерти вновь наблюдается рост числа умерших от старости на фоне снижения смертности от других причин [Вишневский, Андреев, Тимонин 2016]. Хотя особенности смертности от неустановленных причин смерти в Москве носят несколько иной характер по сравнению с Россией и в большей степени затрагивают смертность в трудоспособном возрасте, ее изменения (следующие друг за другом быстрый рост и затем резкое снижение в 1990-е, 2000-е и особенно 2010-е годы, когда в результате снижения уровня смертности от неопределенных причин заметно выросла смертность от сердечно-сосудистых заболеваний) внушают опасения, что их драйвером также являются административные решения, а не устойчивые, научно-обоснованные и рациональные изменения практики регистрации и кодирования причин смерти.

По результатам исследования в Барнауле было показано, что около 14\% смертей мужчин в возрасте 35-69 лет от болезней системы кровообращения должно было быть отнесено к отравлениям алкоголем [Zaridze et al. 2009]. Однако другие исследования, направленные на выяснение полноты данных о смертности от алкогольных отравлений, а именно отнесения таких случаев смерти к смертности от болезней системы кровообращения, показали иные результаты: в Ижевске и Архангельске [Shkolnikov et al. 2002; Sidorenkov et al. 2011] не было выявлено широкой распространенности такой практики, а также было показано, что в наличие потенциально смертельного уровня алкоголя в крови не является однозначным критерием для отнесения смерти к отравлениям алкоголем.

Исследования, направленные на выяснение степени сопоставимости практик кодирования некоторых отдельных причин смерти между российскими регионами, показали существенные различия подходов в регионах к установлению причин смерти для смертности от убийств [Pridemore 2003] и смертности, связанной с алкоголем [Немцов 2003]. Кроме того, было показано, что значительная часть смертей от неустановленных причин в трудоспособном возрасте приходится на внешние причины смерти [Gavrilova et al. 2008]. Также была показана недорегистрация смертности от диабета [Рощин, Сабгайда, Евдокушкина 2012]. 
Ряд структурных особенностей смертности в Москве имеет сходство со среднероссийскими тенденциями. Москва, как и Россия в целом, характеризуется высокой долей болезней системы кровообращения в структуре причин смерти, при этом сохраняется высокая доля ишемической болезни сердца и низкая доля смертей от прочих БСК.

Вместе с тем статистика смертности в Москве, по сравнению с Россией, по всей видимости более полно отражает смертность от установленных причин смерти в пожилых возрастах. Так, смертность от новообразований в возрасте старше 80 лет в Москве выше, чем в России; это указывает на более объективный выбор первоначальной причины смерти с учётом того, что коэффициенты смертности в пожилом возрасте в Москве в целом занижены за счет завышения численности населения. При этом среди женщин заниженность смертности от основных причин проявляется существенно меньше, чем среди мужчин. Таким образом, возрастной профиль смертности от основных причин в Москве выглядит более приближенным к закономерностям, наблюдаемым в европейских странах.

В период до начала устойчивого снижения смертности основной вклад в формирование разницы между Москвой и Россией по уровню ОПЖ вносили тенденции изменения смертности в трудоспособном возрасте, а по мере устойчивого роста ОПЖ все большую роль приобретают более старшие возрастные группы. Предположительно завышенная численность населения в пожилом возрасте существенно искажает показатели смертности в данной возрастной группе, однако можно предположить, что реальная картина смертности населения в этом возрасте в Москве представляет собой промежуточное положение между Россией и европейскими странами.

\section{ЛИТЕРАТУРА}

Андреев Е.М. (1982). Метод компонент в анализе продолжительности жизни. Вестник статистики, 3, 42-47.

Андреев Е.М. (2012). О точности результатов российских переписей населения и степени доверия к разным источникам информации. Вопросы статистики, 11, 21-35.

Андреев Е.М. (2016). Плохо определенные и точно не установленные причины смерти в России. Демографическое обозрение, 3(2), 103-142. doi:10.17323/demreview.v3i2.1755

Андреев Е.М., Кваша Е.А., Харькова Т.Л. (2006). Особые точки на карте смертности. В А.Г. Вишневский (Ред.), Население России 2003-2004. Одиннадизатый-двенадиатый ежегодный демографический доклад (с. 298-305). Москва: Наука.

Андреев Е.М., Кваша Е.А., Харькова Т.Л. (2016). Смертность в Москве и других мегаполисах мира: сходства и различия. Демографическое обозрение, 3(3), 39-79. doi:10.17323/demreview.v3i3

Андреев Е.М., Школьников В.М. (2018). Связь между уровнями смертности и экономического развития в России и ее регионах. Демографическое обозрение, 5(1), 624. doi:10.17323/demreview.v5i1.7707

Архангельский В.Н., Иванова А.Е., Рыбаковский Л.Л., Рязанцев С.В. (2006). Демографическая ситуация в Москве и тенденции ее развития. Москва: Центр социального прогнозирования. 
Васин С.А. (2015). Смертность от повреждений с неопределенными намерениями в России и в других странах. Демографическое обозрение, 2(1), 89-124. doi:/10.17323/demreview.v2i1.1790

Вишневский А.Г., Андреев Е.М., Тимонин С.А. (2016). Смертность от болезней системы кровообращения и продолжительность жизни в России. Демографическое обозрение, 3(1), 6-34. doi:10.17323/demreview.v3i1.1761

Данилова И.А. (2015). Проблемы качества российской статистики причин смерти в старческом возрасте. Успехи геронтологии, 28(3), 409-414.

Иванова А.Е., Сабгайда Т.П., Семенова В.Г., Запороженко В.Г., Землянова Е.В., Никитина C.Ю. (2013). Факторы искажения структуры причин смерти трудоспособного населения России. Социальные аспекты здоровья населения, 4(32). URL: http://vestnik.mednet.ru/content/view/491/30/lang,ru/

Мкртчян Н.В. (2012). Проблемы учета населения отдельных возрастных групп в ходе переписи населения 2010 г.: причины отклонений полученных данных от ожидаемых. В М.Б. Денисенко (Ред.), Демографические аспекты сочииально-экономического развития, вып. 22 (с. 197-214). Москва: МАКС Пресс.

Немцов А.В. (2003). Алкогольный урон регионов России. Москва: NALEX.

Папанова Е.К., Школьников В.М., Андреев Е.М., Тимонин С.А. (2017). Высокая продолжительность жизни москвичей после 80 лет - реальность или статистический артефакт? Успехи геронтологии, 30(6), 826-835.

Ревич Б.А. (2011). Волны жары, качество атмосферного воздуха и смертность населения европейской части России летом 2010 г.: результаты предварительной оценки. Экология человека, 7, 3-9.

Рощин Д.О., Т.П. Сабгайда, Г.Н. Евдокушкина (2012). Проблема учета наличия сахарного диабета при диагностике причин смерти. Социальные аспекты здоровья населения, 5(27). URL: http://vestnik.mednet.ru/content/view/430/30/lang,ru/

Семенова В.Г., Антонова О.И. (2007). Достоверность статистики смертности (на примере смертности от травм и отравлений в Москве). Социальные аспекты здоровья населения, 2. URL: http://vestnik.mednet.ru/content/view/28/30/

Харькова Т.Л., Никитина С.Ю., Андреев Е.М. (2017). Зависимость продолжительности жизни от уровня образования в России. Вопросы статистики, 8, 61-68.

ЦДИ РЭШ. (2018). Российская база данных по рождаемости и смертности (РОСБРиС). URL: http://www.demogr.nes.ru/index.php/ru/demogr_indicat/data (данные загружены 05.07.2018).

Andreev E.M., Shkolnikov V.M., Begun A.Z. (2002). Algorithm for decomposition of differences between aggregate demographic measures and its application to life expectancies, healthy life expectancies, parity-progression ratios and total fertility rates. Demographic Research, 7(14), 499-522. doi:10.4054/DemRes.2002.7.14.

Danilova I.A., Shkolnikov V.M., Jdanov D.A., Meslé F., Vallin J. (2016). Identifying potential differences in cause-of-death coding practices across Russian regions. Population Health Metrics, 14(8). doi:10.1186/s12963-016-0078-0

Eurostat (2018). Amenable and preventable deaths statistics. URL: http://ec.europa.eu/eurostat/statisticsexplained/index.php/Amenable_and_preventable_deaths_statistics (data downloaded on 15.09.2018). 
Gavrilova N.S., Semyonova V.G., Dubrovina E., Evdokushkina G.N., Ivanova A.E., Gavrilov L.A. (2008). Russian Mortality Crisis and the Quality of Vital Statistics. Population Research and Policy Review, 27, 551-574. doi:10.1007/s11113-008-9085-6

Gusmano M.K., Rodwin V.G., Wang C., Weisz D., Luo L., Hua F. (2015). Shanghai rising: health improvements as measured by avoidable mortality since 2000. International Journal of Health Policy and Management, 4(1), 7-12. http://doi.org/10.15171/ijhpm.2015.07

Gusmano M.K., Rodwin V.G., Weisz D., Ayoub R. (2016). Health Improvements in BRIC Cities: Moscow, São Paulo, and Shanghai, 2000-10. World Medical \& Health Policy, 8, 127138. doi:10.1002/wmh3.188

Jdanov D.A., Scholz R.D., Shkolnikov V.M. (2005). Official population statistics and the Human Mortality Database estimates of populations aged 80+ in Germany and nine other European countries. Demographic Research, 13(14), 335-362. doi:10.4054/DemRes.2005.13.14

Koster E.M., de Gelder R. , Di Nardo F., Williams G., Harrison A., van Buren L.P., Lyshol H., Patterson L., Birt C.A., Higgerson J., Achterberg P.W., Verma A., van Ameijden E.J.C. (2017). Health status in Europe: comparison of 24 urban areas to the corresponding 10 countries (EURO-URHIS 2). European Journal of Public Health, 27(2), 62-67. doi:10.1093/eurpub/ckw188

Preston S., Elo I. (2014). Anatomy of a Municipal Triumph: New York City's Upsurge in Life Expectancy. Population and Development Review, 40(1), 1-29. doi:10.1111/j.17284457.2014.00648.x

Pridemore W.A. (2003). Measuring homicide in Russia: a comparison of estimates from the crime and vital statistics reporting system. Social Science \& Medicine, 57(8), 1343-1354. doi:10.1016/S0277-9536 (02) 00509-9

Shaposhnikov D., Revich B., Bellander T., Bedada G.B., Bottai M., Kharkova T., Kvasha E., Lezina E., Lind T., Semutnikova E., Pershagen G. (2014). Mortality Related to Interactions Between Heat Wave and Wildfire Air Pollu-tion During the Summer of 2010 in Moscow. Epidemiology, 3(25), 359-364. doi:10.1097/EDE.0000000000000090

Shkolnikov V.M., Andreev E.M., Jasilionis D., Leinsalu M., Antonova O.I., McKee M. (2006). The Changing Relation between Education and Life Expectancy in Central and Eastern Europe in the 1990s. Journal of Epidemiology and Community Health, 60(10), 875-881.

Shkolnikov V.M., Andreev E.M., McKee M., Leon D.A. (2013). Components and possible determinants of the decrease in Russian mortality in 2004-2010. Demographic Research, 28(32), 917-950. doi:10.4054/DemRes.2013.28.32

Shkolnikov V.M., Cornia G.A. (2000). Population crisis and rising mortality in transitional Russia. In G.A. Cornia, R. Paniccià (Eds.), The mortality crisis in transitional economies (pp. 253-279). Oxford: Oxford University Press.

Shkolnikov V.M., Cornia G.A., Leon D.A., Meslé F. (1998a). Causes of the Russian Mortality Crisis: Evidence and Interpretations. World Development, 26(6), 1995-2011.

Shkolnikov V.M., Leon D.A., Adamets S., Andreev E.M., Deev A. (1998b). Educational Level and Adult Mortality in Russia: An Analysis of Routine Data 1979 to 1994. Social Science and Medicine, 47(3), 357-369.

Shkolnikov V.M., McKee M., Chervyakov V.V., Kiryanov N.A. (2002). Is the link between alcohol and cardiovascular death among young Russian men attributable to misclassification 
of acute alcohol intoxication? Evidence from the city of Izhevsk. Journal of Epidemiology and Community Health, 56(3), 171-174. doi:10.1136/jech.56.3.171

Shkolnikov V.M., McKee M., Vallin J., Aksel E., Leon D., Chenet L., Meslé F. (1999). Cancer mortality in Russia and Ukraine: validity, competing risks, and cohort effects. International Journal of Epidemiology, 28, 19-29.

Shkolnikov V.M., Meslé F., Vallin J. (1996). Health Crisis in Russia I. Recent Trends in Life Expectancy and Causes of Death from 1970 to 1993. Population: An English Selection, 8, $123-154$.

Sidorenkov O., Nilssen O., Nieboer E., Kleschinov N., Grjibovski A.M. (2011). Premature cardiovascular mortality and alcohol consumption before death in Arkhangelsk, Russia: an analysis of a consecutive series of forensic autopsies. International Journal of Epidemiology, 40(6), 1519-1529. doi:0.1093/ije/dyr145

Thatcher A.R., Kannisto V., Andreev K.F. (2002). The survivor ratio method for estimating numbers at high ages. Demographic Research, 6(1), 1-16. doi:10.4054/DemRes.2002.6.1

Timonin S.A., Danilova I.A., Andreev E.M., Shkolnikov V.M. (2017). Recent mortality trend reversal in Russia: are regions following the same tempo? European Journal of Population, 33(5), 733-763. doi:10.1007/s10680-017-9451-3

Todd M.A., Shkolnikov V.M., Goldman N. (2016). Why are well-educated Muscovites more likely to survive? Understanding the biological pathways. Social Science \& Medicine, 157, 138-147. http://doi.org/10.1016/j.socscimed.2016.02.041 V.M.

University of California, Berkeley, Max Planck Institute for Demographic Research (MPIDR). (2018). Human Mortality Database. URL: http://www.mortality.org. (данные загружены 20.06.2018).

Vallin J., Andreev E.M., Meslém F., Shkolnikov (2005). Geographical diversity of cause-ofdeath patterns and trends in Russia. Demographic Research, 12(13), 323-380.

WHO Regional Office for Europe. (2018). European Health for All database (HFA-DB). URL: https://gateway.euro.who.int/en/datasets/european-health-for-all-database/ (данные загружены 15.09.2018).

WHO. (2018). World Health Organization Mortality Database. URL: http://www.who.int/healthinfo/mortality_data/en/ (данные загружены 10.06.2018).

Zaridze D., Maximovitch D., Lazarev A., Igitov V., Boroda A., Boreham J. et al. (2009). Alcohol poisoning is a main determinant of recent mortality trends in Russia : evidence from a detailed analysis of mortality statistics and autopsies. International Journal of Epidemiology, 38(1), 143-153. doi:10.1093/ije/dyn160

Zemlyanova E., Lopakov K., Ivanova A. (2017). Regional mortality differences in big Russian cities. European Journal of Public Health, 27(3). doi:10.1093/eurpub/ckx186.007 


\section{ПРИЛОЖЕНИЕ}

Таблица 1. Ожидаемая продолжительность жизни в Москве, России, ЦФО и некоторых странах, 1969-1970, 1978-1979, 1989-2017 гг., лет

\begin{tabular}{|c|c|c|c|c|c|c|c|c|}
\hline & Москва & Россия & $\begin{array}{c}\text { Россия без } \\
\text { Москвы }\end{array}$ & $\begin{array}{c}\text { ЦФО без } \\
\text { Москвы }\end{array}$ & Чехия & Эстония & Франция & Швеция \\
\hline \multicolumn{9}{|c|}{ Ожидаемая продолжительность жизни при рождении, мужчины } \\
\hline $\begin{array}{l}1969 \\
(1969-1970)\end{array}$ & 65,2 & 63,2 & 62,9 & 63,7 & 65,8 & 65,4 & 67,4 & 71,7 \\
\hline $\begin{array}{l}1978 \\
(1978-1979)\end{array}$ & 64,0 & 61,9 & 61,5 & 62,0 & 67,2 & 64,3 & 69,8 & 72,5 \\
\hline 1989 & 65,1 & 64,2 & 64,2 & 64,1 & 68,1 & 65,7 & 72,5 & 74,8 \\
\hline 1990 & 64,9 & 63,8 & 63,7 & 63,6 & 67,5 & 64,7 & 72,7 & 74,8 \\
\hline 1991 & 65,0 & 63,4 & 63,3 & 63,1 & 68,2 & 64,5 & 72,9 & 75,0 \\
\hline 1992 & 63,4 & 62,0 & 61,9 & 62,0 & 68,5 & 63,5 & 73,2 & 75,4 \\
\hline 1993 & 59,4 & 58,8 & 58,8 & 59,2 & 69,3 & 62,5 & 73,3 & 75,5 \\
\hline 1994 & 57,7 & 57,4 & 57,4 & 57,4 & 69,5 & 60,8 & 73,6 & 76,1 \\
\hline 1995 & 59,0 & 58,1 & 58,1 & 58,2 & 69,7 & 61,6 & 73,8 & 76,2 \\
\hline 1996 & 62,4 & 59,6 & 59,5 & 59,6 & 70,3 & 64,4 & 74,1 & 76,5 \\
\hline 1997 & 64,5 & 60,9 & 60,6 & 60,6 & 70,4 & 64,5 & 74,5 & 76,7 \\
\hline 1998 & 64,8 & 61,2 & 61,0 & 60,8 & 71,1 & 64,3 & 74,7 & 76,9 \\
\hline 1999 & 64,7 & 59,9 & 59,6 & 59,0 & 71,3 & 65,2 & 74,9 & 77,1 \\
\hline 2000 & 64,6 & 59,0 & 58,6 & 58,2 & 71,6 & 65,6 & 75,2 & 77,4 \\
\hline 2001 & 64,4 & 58,9 & 58,5 & 57,7 & 72,0 & 65,2 & 75,4 & 77,5 \\
\hline 2002 & 64,8 & 58,7 & 58,2 & 57,4 & 72,1 & 65,6 & 75,7 & 77,7 \\
\hline 2003 & 65,0 & 58,5 & 58,1 & 57,5 & 72,1 & 66,5 & 75,8 & 77,9 \\
\hline 2004 & 65,9 & 58,9 & 58,4 & 57,8 & 72,6 & 66,7 & 76,7 & 78,4 \\
\hline 2005 & 66,7 & 58,9 & 58,4 & 57,8 & 73,0 & 67,6 & 76,7 & 78,4 \\
\hline 2006 & 67,2 & 60,4 & 59,9 & 59,4 & 73,5 & 67,6 & 77,2 & 78,7 \\
\hline 2007 & 68,1 & 61,4 & 60,9 & 60,2 & 73,7 & 67,5 & 77,4 & 78,9 \\
\hline 2008 & 68,6 & 61,9 & 61,4 & 60,7 & 74,0 & 68,9 & 77,6 & 79,1 \\
\hline 2009 & 69,6 & 62,9 & 62,4 & 61,8 & 74,2 & 70,0 & 77,8 & 79,3 \\
\hline 2010 & 69,9 & 63,1 & 62,6 & 62,2 & 74,4 & 70,8 & 78,0 & 79,5 \\
\hline 2011 & 71,5 & 64,0 & 63,5 & 63,5 & 74,7 & 71,3 & 78,4 & 79,8 \\
\hline 2012 & 71,6 & 64,5 & 64,0 & 63,8 & 75,0 & 71,3 & 78,5 & 79,9 \\
\hline 2013 & 72,3 & 65,1 & 64,6 & 64,4 & 75,2 & 72,7 & 78,8 & 80,1 \\
\hline 2014 & 72,8 & 65,3 & 64,7 & 64,4 & 75,7 & 72,3 & 79,3 & 80,4 \\
\hline 2015 & 73,0 & 65,9 & 65,4 & 65,5 & 75,6 & - & 79,0 & 80,3 \\
\hline 2016 & 73,5 & 66,5 & 65,9 & 65,9 & 76,1 & - & - & 80,6 \\
\hline 2017 & 74,4 & 67,5 & 67,0 & 66,9 & & - & - & - \\
\hline \multicolumn{9}{|c|}{ Ожидаемая продолжительность жизни при рождении, женщинь } \\
\hline $\begin{array}{l}1969 \\
(1969-1970)\end{array}$ & 73,8 & 73,4 & 73,4 & 74,2 & 73,1 & 74,4 & 75,1 & 76,6 \\
\hline $\begin{array}{l}1978 \\
(1978-1979)\end{array}$ & 73,5 & 73,3 & 73,2 & 74,2 & 74,3 & 74,5 & 78,0 & 78,7 \\
\hline 1989 & 74,1 & 74,5 & 74,5 & 75,0 & 75,4 & 74,9 & 80,7 & 80,6 \\
\hline 1990 & 74,0 & 74,3 & 74,3 & 74,8 & 75,4 & 74,9 & 81,0 & 80,4 \\
\hline 1991 & 74,2 & 74,2 & 74,2 & 74,7 & 75,8 & 75,0 & 81,2 & 80,5 \\
\hline 1992 & 74,0 & 73,7 & 73,7 & 74,2 & 76,2 & 74,8 & 81,5 & 80,8 \\
\hline 1993 & 72,1 & 71,9 & 71,8 & 72,7 & 76,4 & 74,1 & 81,5 & 80,8 \\
\hline 1994 & 71,5 & 71,1 & 71,0 & 71,7 & 76,7 & 73,0 & 81,9 & 81,4 \\
\hline 1995 & 72,1 & 71,6 & 71,6 & 72,3 & 76,7 & 74,4 & 81,9 & 81,4 \\
\hline 1996 & 73,8 & 72,4 & 72,3 & 72,9 & 77,3 & 75,6 & 82,1 & 81,5 \\
\hline 1997 & 74,3 & 72,8 & 72,7 & 73,2 & 77,4 & 75,9 & 82,3 & 81,8 \\
\hline 1998 & 74,5 & 73,1 & 73,0 & 73,3 & 78,0 & 75,4 & 82,4 & 81,9 \\
\hline 1999 & 74,7 & 72,4 & 72,3 & 72,4 & 78,1 & 76,1 & 82,5 & 81,9 \\
\hline 2000 & 75,0 & 72,2 & 72,1 & 72,3 & 78,3 & 76,3 & 82,8 & 82,0 \\
\hline 2001 & 74,7 & 72,2 & 72,0 & 72,2 & 78,5 & 76,5 & 82,9 & 82,1 \\
\hline 2002 & 74,8 & 71,9 & 71,7 & 71,8 & 78,7 & 77,2 & 83,0 & 82,1 \\
\hline
\end{tabular}




\begin{tabular}{|c|c|c|c|c|c|c|c|c|}
\hline & Москва & Россия & $\begin{array}{c}\text { Россия без } \\
\text { Москвы }\end{array}$ & $\begin{array}{c}\text { ЦФО без } \\
\text { Москвы }\end{array}$ & Чехия & Эстония & Франция & Швеция \\
\hline 2003 & 75,0 & 71,8 & 71,6 & 71,9 & 78,7 & 77,3 & 83,0 & 82,4 \\
\hline 2004 & 75,8 & 72,4 & 72,1 & 72,4 & 79,2 & 78,0 & 83,9 & 82,7 \\
\hline 2005 & 76,3 & 72,5 & 72,2 & 72,6 & 79,3 & 78,3 & 83,8 & 82,8 \\
\hline 2006 & 76,9 & 73,3 & 73,0 & 73,2 & 79,9 & 78,6 & 84,2 & 82,9 \\
\hline 2007 & 77,5 & 74,0 & 73,7 & 73,9 & 80,1 & 78,8 & 84,4 & 83,0 \\
\hline 2008 & 77,7 & 74,3 & 74,0 & 74,1 & 80,3 & 79,5 & 84,3 & 83,1 \\
\hline 2009 & 78,3 & 74,8 & 74,5 & 74,7 & 80,3 & 80,1 & 84,4 & 83,3 \\
\hline 2010 & 78,1 & 74,9 & 74,6 & 74,7 & 80,6 & 80,6 & 84,7 & 83,5 \\
\hline 2011 & 79,8 & 75,6 & 75,3 & 75,6 & 80,9 & 81,0 & 85,0 & 83,7 \\
\hline 2012 & 79,6 & 75,8 & 75,5 & 75,8 & 81,0 & 81,2 & 84,8 & 83,5 \\
\hline 2013 & 80,2 & 76,3 & 76,0 & 76,1 & 81,2 & 81,4 & 85,0 & 83,7 \\
\hline 2014 & 80,4 & 76,5 & 76,2 & 76,4 & 81,7 & 81,5 & 85,4 & 84,1 \\
\hline 2015 & 80,3 & 76,7 & 76,4 & 76,7 & 81,5 & - & 85,1 & 84,0 \\
\hline 2016 & 80,4 & 77,1 & 76,8 & 76,9 & 81,9 & - & - & 84,1 \\
\hline 2017 & 81,1 & 77,7 & 77,4 & 77,5 & - & & - & - \\
\hline \multicolumn{9}{|c|}{ Ожидаемая продолжсиельность жизни в интервале возраста 15-59 лет, мужчинь } \\
\hline $\begin{array}{l}1969 \\
(1969-1970)\end{array}$ & 41,6 & 40,5 & 40,4 & 40,7 & 42,2 & 41,3 & 42,3 & 43,2 \\
\hline $\begin{array}{l}1978 \\
(1978-1979)\end{array}$ & 41,1 & 39,9 & & 39,8 & 42,5 & 40,8 & 42,5 & 43,2 \\
\hline 1989 & 41,6 & 41,0 & 41,0 & 40,9 & 42,7 & 41,4 & 42,8 & 43,5 \\
\hline 1990 & 41,2 & 40,6 & 40,6 & 40,5 & 42,5 & 40,9 & 42,8 & 43,6 \\
\hline 1991 & 41,2 & 40,5 & 40,4 & 40,3 & 42,6 & 40,7 & 42,8 & 43,6 \\
\hline 1992 & 40,4 & 39,7 & 39,7 & 39,7 & 42,6 & 40,5 & 42,8 & 43,7 \\
\hline 1993 & 38,6 & 38,4 & 38,4 & 38,6 & 42,7 & 39,9 & 42,8 & 43,8 \\
\hline 1994 & 37,8 & 37,8 & 37,8 & 37,8 & 42,7 & 39,0 & 42,9 & 43,8 \\
\hline 1995 & 38,1 & 38,0 & 38,0 & 38,0 & 42,8 & 39,5 & 42,9 & 43,8 \\
\hline 1996 & 39,6 & 38,7 & 38,6 & 38,7 & 42,9 & 40,7 & 43,0 & 43,9 \\
\hline 1997 & 40,5 & 39,3 & 39,2 & 39,2 & 42,9 & 40,4 & 43,1 & 43,9 \\
\hline 1998 & 40,6 & 39,3 & 39,3 & 39,2 & 43,0 & 40,5 & 43,2 & 43,9 \\
\hline 1999 & 40,5 & 38,8 & 38,6 & 38,4 & 43,1 & 40,8 & 43,2 & 43,9 \\
\hline 2000 & 40,5 & 38,3 & 38,1 & 37,9 & 43,1 & 41,0 & 43,3 & 43,9 \\
\hline 2001 & 40,6 & 38,3 & 38,1 & 37,8 & 43,2 & 40,8 & 43,3 & 43,9 \\
\hline 2002 & 40,7 & 38,2 & 38,0 & 37,6 & 43,2 & 40,7 & 43,3 & 44,0 \\
\hline 2003 & 40,7 & 38,1 & 37,9 & 37,6 & 43,2 & 41,3 & 43,4 & 44,0 \\
\hline 2004 & 40,8 & 38,1 & 37,9 & 37,6 & 43,3 & 41,2 & 43,5 & 44,0 \\
\hline 2005 & 40,9 & 38,0 & 37,8 & 37,5 & 43,3 & 41,6 & 43,5 & 44,1 \\
\hline 2006 & 40,9 & 38,6 & 38,4 & 38,1 & 43,4 & 41,6 & 43,6 & 44,1 \\
\hline 2007 & 41,1 & 39,0 & 38,8 & 38,5 & 43,4 & 41,4 & 43,6 & 44,1 \\
\hline 2008 & 41,2 & 39,2 & 39,0 & 38,7 & 43,5 & 42,0 & 43,6 & 44,1 \\
\hline 2009 & 41,5 & 39,7 & 39,5 & 39,3 & 43,5 & 42,2 & 43,6 & 44,1 \\
\hline 2010 & 41,7 & 39,7 & 39,6 & 39,5 & 43,6 & 42,5 & 43,7 & 44,1 \\
\hline 2011 & 41,9 & 40,0 & 39,9 & 39,9 & 43,6 & 42,5 & 43,7 & 44,1 \\
\hline 2012 & 41,8 & 40,2 & 40,1 & 40,1 & 43,7 & 42,4 & 43,8 & 44,2 \\
\hline 2013 & 41,9 & 40,4 & 40,2 & 40,2 & 43,7 & 43,0 & 43,8 & 44,2 \\
\hline 2014 & 41,9 & 40,4 & 40,2 & 40,1 & 43,7 & 42,8 & 43,9 & 44,2 \\
\hline 2015 & 42,2 & 40,7 & 40,5 & 40,7 & 43,8 & - & 43,9 & 44,1 \\
\hline 2016 & 42,4 & 40,9 & 40,8 & 40,9 & 43,8 & - & - & 44,2 \\
\hline 2017 & 42,5 & 41,3 & 41,1 & 41,3 & - & - & - & - \\
\hline
\end{tabular}

$\begin{array}{lllllllll}1969 & 43,7 & 43,4 & 43,4 & 43,7 & 43,8 & 43,7 & 43,7 & 44,0 \\ 1969-1970) & & & & 43,6 & 43,9 & 43,7 & 43,9 & 44,1 \\ (1978-1979) & 43,7 & 43,4 & & 43,7 \\ 1989 & 43,7 & 43,7 & 43,7 & 43,7 & 44,0 & 43,6 & 44,1 & 44,2 \\ 1990 & 43,6 & 43,6 & 43,6 & 43,7 & 44,0 & 43,7 & 44,1 & 44,3 \\ 1991 & 43,6 & 43,5 & 43,5 & 43,6 & 44,0 & 43,7 & 44,1 & 44,3 \\ 1992 & 43,5 & 43,4 & 43,4 & 43,5 & 44,0 & 43,7 & 44,1 & 44,3 \\ 1993 & 43,0 & 43,0 & 43,0 & 43,2 & 44,1 & 43,5 & 44,1 & 44,3\end{array}$




\begin{tabular}{|c|c|c|c|c|c|c|c|c|}
\hline & Москва & Россия & $\begin{array}{c}\text { Россия без } \\
\text { Москвы }\end{array}$ & $\begin{array}{l}\text { ЦФО без } \\
\text { Москвы }\end{array}$ & Чехия & Эстония & Франция & Швеция \\
\hline 1994 & 42,8 & 42,8 & 42,8 & 42,9 & 44,1 & 42,9 & 44,2 & 44,3 \\
\hline 1995 & 42,8 & 42,9 & 42,9 & 43,0 & 44,1 & 43,4 & 44,1 & 44,4 \\
\hline 1996 & 43,2 & 43,1 & 43,0 & 43,2 & 44,2 & 43,7 & 44,2 & 44,4 \\
\hline 1997 & 43,4 & 43,2 & 43,2 & 43,3 & 44,1 & 43,7 & 44,2 & 44,4 \\
\hline 1998 & 43,5 & 43,2 & 43,2 & 43,3 & 44,2 & 43,6 & 44,2 & 44,4 \\
\hline 1999 & 43,4 & 43,1 & 43,0 & 43,1 & 44,2 & 43,7 & 44,2 & 44,4 \\
\hline 2000 & 43,5 & 43,0 & 42,9 & 43,0 & 44,2 & 43,7 & 44,3 & 44,4 \\
\hline 2001 & 43,4 & 42,9 & 42,9 & 43,0 & 44,2 & 43,7 & 44,3 & 44,4 \\
\hline 2002 & 43,4 & 42,8 & 42,8 & 42,8 & 44,2 & 43,7 & 44,3 & 44,4 \\
\hline 2003 & 43,4 & 42,8 & 42,7 & 42,8 & 44,2 & 43,8 & 44,3 & 44,4 \\
\hline 2004 & 43,5 & 42,8 & 42,7 & 42,8 & 44,3 & 44,0 & 44,3 & 44,5 \\
\hline 2005 & 43,6 & 42,8 & 42,7 & 42,7 & 44,3 & 43,9 & 44,3 & 44,5 \\
\hline 2006 & 43,7 & 42,9 & 42,9 & 42,9 & 44,3 & 43,9 & 44,4 & 44,5 \\
\hline 2007 & 43,7 & 43,0 & 43,0 & 42,9 & 44,4 & 43,9 & 44,4 & 44,5 \\
\hline 2008 & 43,7 & 43,1 & 43,0 & 43,0 & 44,3 & 44,0 & 44,4 & 44,5 \\
\hline 2009 & 43,8 & 43,2 & 43,1 & 43,1 & 44,4 & 44,1 & 44,4 & 44,5 \\
\hline 2010 & 43,8 & 43,2 & 43,2 & 43,2 & 44,4 & 44,2 & 44,4 & 44,5 \\
\hline 2011 & 43,9 & 43,3 & 43,2 & 43,3 & 44,4 & 44,1 & 44,4 & 44,5 \\
\hline 2012 & 43,9 & 43,4 & 43,3 & 43,4 & 44,4 & 44,2 & 44,4 & 44,5 \\
\hline 2013 & 44,0 & 43,4 & 43,4 & 43,5 & 44,4 & 44,3 & 44,5 & 44,5 \\
\hline 2014 & 43,9 & 43,4 & 43,3 & 43,4 & 44,5 & 44,2 & 44,5 & 44,5 \\
\hline 2015 & 44,0 & 43,4 & 43,4 & 43,5 & 44,5 & - & 44,5 & 44,6 \\
\hline 2016 & 44,0 & 43,5 & 43,5 & 43,6 & 44,4 & - & - & 44,6 \\
\hline 2017 & 44,1 & 43,6 & 43,6 & 43,7 & - & - & - & - \\
\hline & \multicolumn{8}{|c|}{ Ожидаемая продолжсительность жизни в возрасте 60 лет, мужчинь } \\
\hline $\begin{array}{l}1969 \\
(1969-1970)\end{array}$ & 14,9 & 14,9 & 14,9 & 14,8 & 14,0 & 15,0 & 15,6 & 17,4 \\
\hline $\begin{array}{l}1978 \\
(1978-1979)\end{array}$ & 14,7 & 14,6 & 14,5 & 14,5 & 14,6 & 15,1 & 17,0 & 17,8 \\
\hline 1989 & 15,0 & 14,9 & 14,9 & 14,8 & 14,7 & 15,3 & 18,8 & 19,2 \\
\hline 1990 & 14,9 & 14,7 & 14,7 & 14,5 & 14,6 & 14,8 & 19,0 & 19,1 \\
\hline 1991 & 14,9 & 14,6 & 14,6 & 14,5 & 15,0 & 15,0 & 19,2 & 19,2 \\
\hline 1992 & 14,7 & 14,4 & 14,4 & 14,3 & 15,3 & 14,5 & 19,3 & 19,3 \\
\hline 1993 & 13,3 & 13,1 & 13,1 & 13,0 & 15,6 & 14,2 & 19,4 & 19,4 \\
\hline 1994 & 13,0 & 12,6 & 12,6 & 12,4 & 15,8 & 14,0 & 19,7 & 19,9 \\
\hline 1995 & 13,7 & 13,1 & 13,0 & 12,9 & 15,8 & 14,4 & 19,6 & 19,8 \\
\hline 1996 & 14,8 & 13,5 & 13,4 & 13,3 & 16,2 & 14,9 & 19,7 & 20,0 \\
\hline 1997 & 15,2 & 13,7 & 13,6 & 13,4 & 16,3 & 15,3 & 19,9 & 20,1 \\
\hline 1998 & 15,4 & 14,0 & 13,9 & 13,6 & 16,6 & 15,0 & 20,0 & 20,3 \\
\hline 1999 & 15,3 & 13,4 & 13,3 & 13,0 & 16,8 & 15,3 & 20,1 & 20,4 \\
\hline 2000 & 15,2 & 13,2 & 13,1 & 12,7 & 16,9 & 15,4 & 20,4 & 20,7 \\
\hline 2001 & 15,3 & 13,1 & 13,0 & 12,5 & 17,3 & 15,4 & 20,6 & 20,9 \\
\hline 2002 & 15,5 & 12,8 & 12,6 & 12,2 & 17,3 & 15,5 & 20,8 & 20,9 \\
\hline 2003 & 15,6 & 12,9 & 12,7 & 12,3 & 17,3 & 15,6 & 20,8 & 21,1 \\
\hline 2004 & 16,2 & 13,2 & 13,0 & 12,6 & 17,6 & 15,7 & 21,4 & 21,5 \\
\hline 2005 & 16,8 & 13,3 & 13,0 & 12,7 & 17,8 & 16,0 & 21,4 & 21,4 \\
\hline 2006 & 17,3 & 13,9 & 13,6 & 13,3 & 18,2 & 16,1 & 21,8 & 21,7 \\
\hline 2007 & 17,7 & 14,2 & 13,9 & 13,5 & 18,4 & 16,1 & 21,9 & 21,9 \\
\hline 2008 & 18,0 & 14,3 & 14,0 & 13,6 & 18,6 & 16,6 & 22,0 & 22,0 \\
\hline 2009 & 18,5 & 14,5 & 14,2 & 13,8 & 18,6 & 17,1 & 22,2 & 22,3 \\
\hline 2010 & 18,5 & 14,6 & 14,3 & 13,9 & 18,8 & 17,4 & 22,4 & 22,3 \\
\hline 2011 & 19,9 & 15,1 & 14,8 & 14,6 & 19,0 & 17,9 & 22,7 & 22,5 \\
\hline 2012 & 20,1 & 15,4 & 15,0 & 14,7 & 19,1 & 17,8 & 22,6 & 22,6 \\
\hline 2013 & 20,7 & 15,7 & 15,3 & 15,0 & 19,1 & 18,1 & 22,8 & 22,8 \\
\hline 2014 & 20,9 & 15,9 & 15,5 & 15,1 & 19,5 & 18,2 & 23,2 & 23,0 \\
\hline 2015 & 20,7 & 16,0 & 15,6 & 15,3 & 19,4 & - & 23,0 & 23,0 \\
\hline 2016 & 20,7 & 16,1 & 15,7 & 15,4 & 19,7 & - & - & 23,2 \\
\hline 2017 & 21,4 & 16,5 & 16,0 & 15,7 & - & - & - & - \\
\hline
\end{tabular}




\begin{tabular}{|c|c|c|c|c|c|c|c|c|}
\hline & Москва & Россия & $\begin{array}{c}\text { Россия без } \\
\text { Москвы } \\
\end{array}$ & $\begin{array}{c}\text { ЦФО без } \\
\text { Москвы } \\
\end{array}$ & Чехия & Эстония & Франция & Швеция \\
\hline & \multicolumn{8}{|c|}{ Ожидаемая продолжительность жизни в возрасте 60 лет, женщины } \\
\hline $\begin{array}{l}1969 \\
(1969-1970)\end{array}$ & 19,1 & 19,6 & 19,7 & 19,6 & 18,1 & 19,4 & 20,2 & 20,4 \\
\hline $\begin{array}{l}1978 \\
(1978-1979)\end{array}$ & 19,0 & 19,6 & 19,6 & 19,8 & 18,6 & 19,5 & 22,0 & 22,0 \\
\hline 1989 & 19,3 & 19,7 & 19,7 & 19,9 & 19,1 & 19,9 & 24,0 & 23,4 \\
\hline 1990 & 19,2 & 19,5 & 19,6 & 19,7 & 19,2 & 19,5 & 24,2 & 23,3 \\
\hline 1991 & 19,2 & 19,6 & 19,6 & 19,8 & 19,5 & 19,7 & 24,4 & 23,4 \\
\hline 1992 & 19,3 & 19,5 & 19,5 & 19,6 & 19,8 & 19,8 & 24,7 & 23,5 \\
\hline 1993 & 18,6 & 18,6 & 18,6 & 18,8 & 19,9 & 19,5 & 24,6 & 23,4 \\
\hline 1994 & 18,6 & 18,2 & 18,1 & 18,4 & 20,0 & 19,4 & 25,0 & 24,0 \\
\hline 1995 & 18,9 & 18,5 & 18,5 & 18,8 & 20,1 & 19,9 & 25,0 & 23,9 \\
\hline 1996 & 19,5 & 18,8 & 18,7 & 18,9 & 20,4 & 20,3 & 25,0 & 24,0 \\
\hline 1997 & 19,5 & 18,9 & 18,8 & 18,9 & 20,6 & 20,6 & 25,2 & 24,2 \\
\hline 1998 & 19,6 & 19,0 & 19,0 & 19,0 & 20,9 & 20,3 & 25,3 & 24,3 \\
\hline 1999 & 19,8 & 18,7 & 18,6 & 18,6 & 20,9 & 20,9 & 25,3 & 24,2 \\
\hline 2000 & 19,9 & 18,7 & 18,6 & 18,6 & 21,2 & 21,0 & 25,6 & 24,3 \\
\hline 2001 & 20,0 & 18,7 & 18,6 & 18,5 & 21,3 & 21,4 & 25,7 & 24,3 \\
\hline 2002 & 20,1 & 18,5 & 18,4 & 18,4 & 21,5 & 21,4 & 25,8 & 24,3 \\
\hline 2003 & 20,2 & 18,6 & 18,4 & 18,5 & 21,4 & 21,5 & 25,6 & 24,6 \\
\hline 2004 & 20,8 & 18,9 & 18,8 & 18,9 & 21,8 & 21,9 & 26,5 & 24,8 \\
\hline 2005 & 21,1 & 19,1 & 18,9 & 19,1 & 21,9 & 22,4 & 26,4 & 24,9 \\
\hline 2006 & 21,4 & 19,5 & 19,3 & 19,3 & 22,3 & 22,3 & 26,7 & 25,0 \\
\hline 2007 & 21,8 & 19,8 & 19,7 & 19,7 & 22,5 & 22,5 & 26,9 & 25,0 \\
\hline 2008 & 22,0 & 20,0 & 19,8 & 19,8 & 22,8 & 22,8 & 26,8 & 25,1 \\
\hline 2009 & 22,4 & 20,2 & 20,1 & 20,1 & 22,7 & 23,2 & 26,9 & 25,3 \\
\hline 2010 & 22,2 & 20,2 & 20,1 & 20,0 & 23,0 & 23,3 & 27,1 & 25,3 \\
\hline 2011 & 23,6 & 20,8 & 20,6 & 20,7 & 23,1 & 23,9 & 27,4 & 25,5 \\
\hline 2012 & 23,5 & 21,0 & 20,8 & 20,7 & 23,2 & 24,0 & 27,2 & 25,4 \\
\hline 2013 & 23,9 & 21,3 & 21,0 & 20,9 & 23,3 & 24,1 & 27,4 & 25,6 \\
\hline 2014 & 24,1 & 21,4 & 21,2 & 21,1 & 23,8 & 24,2 & 27,7 & 25,9 \\
\hline 2015 & 23,9 & 21,5 & 21,3 & 21,3 & 23,5 & - & 27,4 & 25,8 \\
\hline 2016 & 24,0 & 21,7 & 21,4 & 21,3 & 24,0 & - & - & 25,9 \\
\hline 2017 & 24,5 & 22,0 & 21,7 & 21,6 & - & - & - & - \\
\hline
\end{tabular}

Таблица 2. Стандартизованные коэффициенты смертности от основных классов причин смерти в Москве, России, Швеции и Эстонии, 1969-1970, 1978-1979, 1989-2017 гг., на 100 тыс. населения 5

\begin{tabular}{l|r|r|c|r|r}
\hline & Москва & Россия & Россия без Москвы & Швеция & Эстония \\
\hline \multirow{3}{*}{$1969-1970$} & 782,7 & 792,1 & 791,7 & 558,2 & - \\
$1978-1979$ (Эстония - 1981) & 871,1 & 921,1 & 924,8 & 571,6 & 987,0 \\
1989 & 850,2 & 855,5 & 856,9 & 443,9 & 864,7 \\
1990 & 874,8 & 866,9 & 867,2 & 446,0 & 926,5 \\
1991 & 883,1 & 862,4 & 861,1 & 440,8 & 874,8 \\
1992 & 895,7 & 892,5 & 892,3 & 421,3 & 931,1 \\
1993 & 1099,8 & 1067,0 & 1064,5 & 419,8 & 945,3 \\
1994 & 1167,1 & 1160,4 & 1160,5 & 390,1 & 986,4 \\
1995 & 1075,4 & 1075,1 & 1075,5 & 393,3 & 928,4 \\
1996 & 917,3 & 1008,0 & 1015,5 & 377,1 & 843,8 \\
1997 & 863,3 & 975,8 & 984,7 & 363,7 & 791,4 \\
1998 & 844,7 & 957,3 & 966,4 & 357,6 & 828,2
\end{tabular}

\footnotetext{
5 Рассчитано по методу прямой стандартизации с использованием европейского стандарта возрастной структуры населения 1976 г.
} 


\begin{tabular}{|c|c|c|c|c|c|}
\hline & Москва & Россия & Россия без Москвы & Швеция & Эстония \\
\hline 1999 & 839,1 & 1040,0 & 1056,7 & 344,9 & 812,0 \\
\hline 2000 & 853,1 & 1086,6 & 1106,7 & 330,0 & 750,4 \\
\hline 2001 & 830,1 & 1102,1 & 1126,4 & 318,5 & 760,8 \\
\hline 2002 & 817,8 & 1151,1 & 1181,7 & 307,9 & 737,6 \\
\hline 2003 & 817,9 & 1172,1 & 1204,4 & 298,9 & 740,0 \\
\hline 2004 & 778,9 & 1131,6 & 1163,7 & 277,6 & 694,8 \\
\hline 2005 & 727,5 & 1133,6 & 1171,1 & 273,8 & 682,5 \\
\hline 2006 & 691,1 & 1046,4 & 1080,4 & 261,9 & 681,7 \\
\hline 2007 & 648,7 & 991,2 & 1025,0 & 252,2 & 650,7 \\
\hline 2008 & 625,2 & 977,9 & 1013,5 & 245,3 & 628,5 \\
\hline 2009 & 585,5 & 926,0 & 961,2 & 235,3 & 583,5 \\
\hline 2010 & 597,8 & 917,2 & 951,0 & 227,5 & 560,6 \\
\hline 2011 & 488,4 & 838,1 & 876,4 & 218,3 & 502,9 \\
\hline 2012 & 482,0 & 800,2 & 836,0 & 215,1 & 501,0 \\
\hline 2013 & 444,1 & 747,4 & 781,8 & 204,4 & 462,4 \\
\hline 2014 & 422,6 & 702,1 & 733,6 & 196,4 & 462,5 \\
\hline 2015 & 402,6 & 666,4 & 682,9 & 195,3 & 423,7 \\
\hline 2016 & 419,2 & 642,3 & 655,5 & - & - \\
\hline 2017 & 411,4 & 603,0 & 558,0 & - & - \\
\hline \multicolumn{6}{|c|}{ Болезни системы кровообращеени, женщины } \\
\hline $1969-1970$ & 538,0 & 540,8 & 540,9 & 374,4 & - \\
\hline 1978-1979 (Эстония - 1981) & 579,4 & 588,4 & 589,1 & 326,4 & 610,4 \\
\hline 1989 & 552,1 & 562,6 & 563,4 & 251,9 & 560,7 \\
\hline 1990 & 563,5 & 561,7 & 561,5 & 255,8 & 557,8 \\
\hline 1991 & 559,0 & 550,5 & 549,8 & 248,4 & 538,7 \\
\hline 1992 & 564,3 & 558,5 & 558,0 & 243,7 & 539,6 \\
\hline 1993 & 643,3 & 638,7 & 638,3 & 241,9 & 566,9 \\
\hline 1994 & 653,1 & 675,5 & 677,2 & 222,4 & 570,8 \\
\hline 1995 & 625,4 & 638,8 & 639,7 & 220,5 & 529,6 \\
\hline 1996 & 565,4 & 612,4 & 616,0 & 217,4 & 490,3 \\
\hline 1997 & 563,1 & 605,0 & 608,2 & 209,9 & 466,9 \\
\hline 1998 & 561,6 & 594,0 & 596,3 & 206,9 & 490,2 \\
\hline 1999 & 534,9 & 631,6 & 639,1 & 205,1 & 450,5 \\
\hline 2000 & 521,8 & 640,6 & 650,0 & 197,3 & 440,8 \\
\hline 2001 & 523,2 & 646,1 & 656,0 & 193,9 & 425,0 \\
\hline 2002 & 519,4 & 668,3 & 680,5 & 192,3 & 427,9 \\
\hline 2003 & 516,6 & 670,0 & 682,6 & 183,5 & 421,1 \\
\hline 2004 & 479,1 & 631,4 & 644,1 & 171,8 & 388,2 \\
\hline 2005 & 464,9 & 627,5 & 641,3 & 163,4 & 373,6 \\
\hline 2006 & 443,1 & 593,1 & 606,1 & 162,9 & 357,4 \\
\hline 2007 & 414,4 & 560,2 & 573,1 & 158,6 & 341,2 \\
\hline 2008 & 400,6 & 550,5 & 564,0 & 154,4 & 335,5 \\
\hline 2009 & 371,4 & 519,2 & 532,7 & 147,8 & 318,6 \\
\hline 2010 & 397,0 & 517,0 & 528,1 & 144,9 & 309,1 \\
\hline 2011 & 313,0 & 469,7 & 484,6 & 139,3 & 277,5 \\
\hline 2012 & 311,7 & 448,7 & 462,2 & 139,2 & 269,3 \\
\hline 2013 & 294,3 & 417,7 & 429,9 & 134,0 & 272,5 \\
\hline 2014 & 286,6 & 382,4 & 391,7 & 127,1 & 256,4 \\
\hline 2015 & 281,6 & 362,2 & 363,0 & 124,4 & 246,5 \\
\hline 2016 & 289,3 & 342,5 & 340,9 & - & - \\
\hline \multirow[t]{2}{*}{2017} & 267,7 & 319,6 & 293,1 & - & - \\
\hline & \multicolumn{4}{|c|}{ Новообразования, мужчинь } & \\
\hline $1969-1970$ & 367,5 & 287,4 & 282,2 & 204,8 & - \\
\hline 1978-1979 (Эстония - 1981) & 358,1 & 283,0 & 277,1 & 228,3 & 273,7 \\
\hline 1989 & 362,7 & 316,3 & 312,2 & 202,2 & 296,9 \\
\hline 1990 & 364,1 & 318,1 & 314,0 & 204,3 & 288,6 \\
\hline 1991 & 352,7 & 319,6 & 316,6 & 204,0 & 319,3 \\
\hline 1992 & 350,6 & 320,0 & 317,2 & 200,8 & 306,8 \\
\hline 1993 & 348,9 & 326,1 & 323,8 & 201,2 & 317,3 \\
\hline 1994 & 331,4 & 320,3 & 319,0 & 196,1 & 299,0 \\
\hline
\end{tabular}




\begin{tabular}{|c|c|c|c|c|c|}
\hline & Москва & Россия & Россия без Москвы & Швеция & Эстония \\
\hline 1995 & 308,4 & 310,9 & 310,7 & 195,1 & 313,0 \\
\hline 1996 & 297,7 & 301,5 & 301,4 & 195,1 & 302,0 \\
\hline 1997 & 287,8 & 298,2 & 298,6 & 200,4 & 305,3 \\
\hline 1998 & 282,7 & 294,4 & 294,8 & 199,5 & 317,0 \\
\hline 1999 & 287,9 & 295,4 & 295,4 & 196,0 & 292,7 \\
\hline 2000 & 283,3 & 292,2 & 292,4 & 191,8 & 294,9 \\
\hline 2001 & 274,7 & 285,6 & 286,1 & 191,1 & 290,8 \\
\hline 2002 & 259,9 & 282,8 & 284,4 & 188,3 & 299,2 \\
\hline 2003 & 256,3 & 278,2 & 279,7 & 192,1 & 292,4 \\
\hline 2004 & 250,8 & 275,3 & 277,1 & 186,9 & 302,0 \\
\hline 2005 & 244,6 & 272,0 & 274,1 & 187,4 & 305,7 \\
\hline 2006 & 235,4 & 266,0 & 268,4 & 183,5 & 300,7 \\
\hline 2007 & 228,5 & 264,9 & 267,9 & 176,5 & 296,8 \\
\hline 2008 & 220,9 & 262,7 & 266,3 & 175,1 & 288,1 \\
\hline 2009 & 217,7 & 265,1 & 269,4 & 172,7 & 285,2 \\
\hline 2010 & 211,9 & 261,3 & 265,9 & 168,7 & 288,2 \\
\hline 2011 & 205,8 & 257,0 & 261,9 & 168,6 & 280,0 \\
\hline 2012 & 196,2 & 250,6 & 256,1 & 166,8 & 281,0 \\
\hline 2013 & 191,7 & 247,8 & 253,3 & 163,0 & 275,2 \\
\hline 2014 & 191,2 & 243,3 & 248,5 & 163,1 & 282,0 \\
\hline 2015 & 190,4 & 243,2 & 243,8 & 163,1 & 278,2 \\
\hline 2016 & 202,2 & 240,6 & 239,7 & - & - \\
\hline \multirow[t]{2}{*}{2017} & 184,6 & 231,1 & 211,7 & - & - \\
\hline & \multicolumn{4}{|c|}{ Новообразования, женщчины } & \\
\hline $1969-1970$ & 199,5 & 147,5 & 144,0 & 164,3 & \\
\hline 1978-1979 (Эстония - 1981) & 193,4 & 136,3 & 132,2 & 163,1 & 140,9 \\
\hline 1989 & 195,4 & 141,7 & 137,7 & 147,5 & 152,6 \\
\hline 1990 & 191,5 & 142,7 & 139,0 & 148,1 & 146,4 \\
\hline 1991 & 189,9 & 142,8 & 139,2 & 146,8 & 159,4 \\
\hline 1992 & 182,4 & 144,2 & 141,3 & 146,6 & 150,1 \\
\hline 1993 & 181,1 & 144,2 & 141,4 & 148,8 & 156,4 \\
\hline 1994 & 177,5 & 144,8 & 142,3 & 141,6 & 152,2 \\
\hline 1995 & 174,4 & 142,5 & 140,1 & 146,1 & 143,8 \\
\hline 1996 & 172,4 & 139,9 & 137,4 & 144,8 & 151,6 \\
\hline 1997 & 169,8 & 139,5 & 137,1 & 144,2 & 151,9 \\
\hline 1998 & 166,5 & 139,0 & 136,8 & 142,7 & 151,5 \\
\hline 1999 & 168,6 & 140,1 & 137,8 & 141,8 & 149,5 \\
\hline 2000 & 169,1 & 139,5 & 137,1 & 143,2 & 149,5 \\
\hline 2001 & 164,8 & 137,4 & 135,1 & 145,1 & 143,1 \\
\hline 2002 & 161,4 & 135,7 & 133,5 & 141,6 & 143,3 \\
\hline 2003 & 157,4 & 135,0 & 133,1 & 140,6 & 137,6 \\
\hline 2004 & 157,7 & 134,6 & 132,7 & 142,9 & 142,6 \\
\hline 2005 & 152,9 & 132,5 & 130,7 & 140,8 & 137,3 \\
\hline 2006 & 152,5 & 131,2 & 129,3 & 139,5 & 144,7 \\
\hline 2007 & 146,4 & 131,1 & 129,7 & 138,0 & 135,7 \\
\hline 2008 & 146,5 & 131,3 & 129,8 & 135,3 & 136,4 \\
\hline 2009 & 143,3 & 132,6 & 131,5 & 132,7 & 137,3 \\
\hline 2010 & 141,4 & 131,5 & 130,5 & 130,0 & 130,4 \\
\hline 2011 & 135,1 & 129,5 & 128,9 & 129,5 & 136,6 \\
\hline 2012 & 132,3 & 127,6 & 127,1 & 130,4 & 134,4 \\
\hline 2013 & 131,7 & 126,9 & 126,4 & 130,4 & 132,2 \\
\hline 2014 & 131,1 & 125,0 & 124,3 & 127,6 & 137,0 \\
\hline 2015 & 130,2 & 125,4 & 122,4 & 126,5 & 133,5 \\
\hline 2016 & 133,1 & 122,3 & 118,8 & - & - \\
\hline \multirow[t]{2}{*}{2017} & 128,8 & 119,0 & 107,0 & - & - \\
\hline & \multicolumn{4}{|c|}{ Внешние причины смерти, мужчины } & \\
\hline $1969-1970$ & 149,2 & 235,0 & 240,6 & 91,2 & - \\
\hline 1978-1979 (Эстония - 1981) & 168,9 & 284,6 & 292,1 & 91,6 & 234,2 \\
\hline 1989 & 142,5 & 215,7 & 220,4 & 73,7 & 182,9 \\
\hline 1990 & 152,9 & 229,6 & 234,6 & 69,2 & 220,4 \\
\hline WWW.DEMREVIEW.HSE.RU & & & & & 95 \\
\hline
\end{tabular}




\begin{tabular}{|c|c|c|c|c|c|}
\hline & Москва & Россия & Россия без Москвы & Швеция & Эстония \\
\hline 1991 & 166,8 & 243,9 & 249,0 & 67,8 & 240,1 \\
\hline 1992 & 231,4 & 297,4 & 301,7 & 62,1 & 262,8 \\
\hline 1993 & 340,0 & 391,8 & 395,2 & 61,0 & 318,6 \\
\hline 1994 & 375,0 & 430,8 & 434,5 & 61,0 & 403,9 \\
\hline 1995 & 350,9 & 404,6 & 408,2 & 57,8 & 351,0 \\
\hline 1996 & 280,2 & 354,7 & 360,0 & 54,6 & 282,4 \\
\hline 1997 & 225,3 & 315,1 & 321,6 & 56,2 & 282,1 \\
\hline 1998 & 232,1 & 311,7 & 317,6 & 55,5 & 289,7 \\
\hline 1999 & 246,4 & 341,9 & 349,3 & 53,1 & 277,3 \\
\hline 2000 & 198,2 & 363,8 & 377,1 & 53,7 & 248,1 \\
\hline 2001 & 197,5 & 378,3 & 393,3 & 58,5 & 275,2 \\
\hline 2002 & 186,3 & 386,3 & 403,5 & 59,1 & 240,1 \\
\hline 2003 & 170,8 & 380,6 & 398,7 & 55,7 & 219,6 \\
\hline 2004 & 151,2 & 368,1 & 387,0 & 62,1 & 215,2 \\
\hline 2005 & 138,6 & 356,2 & 380,7 & 55,0 & 195,4 \\
\hline 2006 & 112,4 & 302,7 & 339,8 & 53,5 & 191,6 \\
\hline 2007 & 100,6 & 276,1 & 310,7 & 56,1 & 194,5 \\
\hline 2008 & 94,2 & 261,0 & 292,7 & 54,4 & 161,2 \\
\hline 2009 & 82,1 & 239,0 & 263,0 & 52,8 & 152,7 \\
\hline 2010 & 74,9 & 230,5 & 253,6 & 50,8 & 131,9 \\
\hline 2011 & 79,0 & 219,0 & 232,1 & 49,2 & 134,3 \\
\hline 2012 & 78,1 & 211,8 & 224,8 & 50,0 & 138,7 \\
\hline 2013 & 72,1 & 203,1 & 215,9 & 51,3 & 115,7 \\
\hline 2014 & 70,9 & 204,4 & 217,6 & 50,7 & 114,1 \\
\hline 2015 & 67,5 & 190,1 & 198,8 & 54,7 & 97,9 \\
\hline 2016 & 77,0 & 179,3 & 186,3 & - & - \\
\hline \multirow[t]{2}{*}{2017} & 75,7 & 162,9 & 155,9 & - & - \\
\hline & \multicolumn{4}{|c|}{ Внешние причины смерти, женщчины } & \\
\hline $1969-1970$ & 42,0 & 50,8 & 51,4 & 42,2 & - \\
\hline 1978-1979 (Эстония - 1981) & 46,9 & 65,9 & 67,2 & 43,9 & 64,5 \\
\hline 1989 & 46,1 & 53,4 & 53,9 & 30,9 & 53,4 \\
\hline 1990 & 46,9 & 56,0 & 56,6 & 30,2 & 54,6 \\
\hline 1991 & 49,0 & 58,4 & 59,0 & 29,2 & 57,3 \\
\hline 1992 & 60,7 & 69,6 & 70,1 & 27,3 & 61,0 \\
\hline 1993 & 79,7 & 92,4 & 93,2 & 26,4 & 70,9 \\
\hline 1994 & 85,5 & 100,9 & 101,9 & 29,7 & 105,6 \\
\hline 1995 & 84,3 & 95,1 & 95,8 & 23,7 & 76,3 \\
\hline 1996 & 70,1 & 84,1 & 85,1 & 23,8 & 63,9 \\
\hline 1997 & 63,7 & 76,1 & 77,0 & 22,8 & 61,0 \\
\hline 1998 & 62,8 & 75,3 & 76,2 & 23,2 & 64,9 \\
\hline 1999 & 68,6 & 81,5 & 82,5 & 23,1 & 61,4 \\
\hline 2000 & 55,6 & 84,3 & 86,5 & 21,7 & 58,9 \\
\hline 2001 & 54,2 & 88,5 & 91,1 & 23,7 & 64,4 \\
\hline 2002 & 53,1 & 91,2 & 94,2 & 22,8 & 54,0 \\
\hline 2003 & 49,5 & 90,4 & 93,7 & 23,0 & 49,2 \\
\hline 2004 & 45,2 & 87,4 & 90,8 & 28,3 & 43,1 \\
\hline 2005 & 40,0 & 83,0 & 87,1 & 24,9 & 45,9 \\
\hline 2006 & 31,7 & 70,8 & 78,9 & 23,0 & 43,5 \\
\hline 2007 & 28,3 & 64,1 & 71,5 & 22,3 & 38,4 \\
\hline 2008 & 25,7 & 60,4 & 67,3 & 22,5 & 34,7 \\
\hline 2009 & 23,4 & 56,7 & 62,4 & 22,2 & 32,6 \\
\hline 2010 & 21,8 & 54,9 & 60,3 & 21,1 & 29,0 \\
\hline 2011 & 23,2 & 52,6 & 55,3 & 20,9 & 28,2 \\
\hline 2012 & 23,2 & 50,8 & 53,3 & 21,3 & 28,6 \\
\hline 2013 & 20,1 & 47,4 & 50,0 & 21,6 & 26,9 \\
\hline 2014 & 21,4 & 47,8 & 50,3 & 22,1 & 24,7 \\
\hline 2015 & 20,1 & 45,5 & 47,1 & 22,5 & 24,4 \\
\hline 2016 & 23,1 & 42,1 & 43,2 & - & - \\
\hline 2017 & 22,6 & 38,6 & 36,6 & - & - \\
\hline
\end{tabular}




\begin{tabular}{|c|c|c|c|c|c|}
\hline & Москва & Россия & Россия без Москвы & Швеция & Эстония \\
\hline \multicolumn{6}{|c|}{ Симптомы, признаки и отклонения от нормы, мужчины } \\
\hline $1969-1970$ & 4,1 & 16,8 & 17,5 & 7,1 & - \\
\hline 1978-1979 (Эстония - 1981) & 4,8 & 5,0 & 5,1 & 5,7 & 18,1 \\
\hline 1989 & 13,8 & 13,8 & 13,9 & 10,9 & 8,7 \\
\hline 1990 & 15,4 & 30,3 & 31,8 & 13,1 & 28,3 \\
\hline 1991 & 15,0 & 41,5 & 44,0 & 12,7 & 39,8 \\
\hline 1992 & 26,4 & 53,2 & 55,9 & 13,0 & 54,2 \\
\hline 1993 & 49,0 & 74,1 & 77,0 & 11,0 & 71,9 \\
\hline 1994 & 60,4 & 85,4 & 88,4 & 10,2 & 63,7 \\
\hline 1995 & 39,9 & 81,9 & 86,1 & 10,8 & 68,5 \\
\hline 1996 & 25,1 & 78,0 & 83,2 & 10,3 & 61,8 \\
\hline 1997 & 15,3 & 74,2 & 80,0 & 14,0 & 65,6 \\
\hline 1998 & 8,3 & 71,0 & 77,1 & 15,5 & 62,6 \\
\hline 1999 & 6,5 & 78,8 & 85,8 & 15,3 & 58,6 \\
\hline 2000 & 49,7 & 90,9 & 95,5 & 15,5 & 56,0 \\
\hline 2001 & 68,2 & 95,3 & 98,9 & 14,6 & 49,6 \\
\hline 2002 & 74,9 & 97,7 & 101,2 & 14,6 & 58,8 \\
\hline 2003 & 83,1 & 104,6 & 108,0 & 14,3 & 54,2 \\
\hline 2004 & 90,7 & 98,9 & 100,7 & 15,4 & 44,9 \\
\hline 2005 & 91,5 & 96,9 & 98,3 & 16,4 & 46,2 \\
\hline 2006 & 83,7 & 85,3 & 86,3 & 16,9 & 42,8 \\
\hline 2007 & 82,6 & 77,2 & 77,6 & 17,0 & 46,6 \\
\hline 2008 & 81,9 & 78,9 & 79,6 & 16,1 & 20,7 \\
\hline 2009 & 68,8 & 75,3 & 77,1 & 18,8 & 18,9 \\
\hline 2010 & 63,4 & 80,5 & 83,4 & 27,4 & 23,4 \\
\hline 2011 & 58,2 & 73,9 & 76,7 & 23,3 & 27,8 \\
\hline 2012 & 69,1 & 76,5 & 78,7 & 18,8 & 22,0 \\
\hline 2013 & 81,9 & 83,7 & 85,7 & 17,5 & 24,0 \\
\hline 2014 & 93,1 & 97,1 & 100,1 & 16,6 & 22,6 \\
\hline 2015 & 115,1 & 92,4 & 91,0 & 17,2 & 28,2 \\
\hline 2016 & 43,0 & 82,7 & 88,2 & - & - \\
\hline \multirow[t]{2}{*}{2017} & 17,5 & 70,0 & 68,4 & - & - \\
\hline & \multicolumn{4}{|c|}{ Симптомы, признаки и отклонения от нормы, женщинь } & \\
\hline $1969-1970$ & 1,9 & 9,4 & 9,9 & 6,0 & - \\
\hline 1978-1979 (Эстония - 1981) & 1,8 & 1,9 & 1,9 & 3,8 & 1,5 \\
\hline 1989 & 3,6 & 6,6 & 6,8 & 9,0 & 3,9 \\
\hline 1990 & 4,2 & 20,9 & 22,2 & 9,8 & 23,3 \\
\hline 1991 & 4,6 & 30,6 & 32,6 & 9,7 & 36,0 \\
\hline 1992 & 7,0 & 37,7 & 40,1 & 9,0 & 42,6 \\
\hline 1993 & 11,0 & 49,4 & 52,4 & 9,2 & 47,3 \\
\hline 1994 & 12,5 & 54,8 & 58,1 & 9,0 & 41,5 \\
\hline 1995 & 8,8 & 55,6 & 59,3 & 9,2 & 44,7 \\
\hline 1996 & 5,7 & 57,3 & 61,3 & 10,2 & 44,8 \\
\hline 1997 & 3,9 & 56,9 & 61,1 & 11,9 & 39,0 \\
\hline 1998 & 2,5 & 54,7 & 58,9 & 13,2 & 40,2 \\
\hline 1999 & 2,3 & 57,2 & 61,7 & 12,9 & 40,5 \\
\hline 2000 & 13,2 & 58,5 & 62,4 & 14,2 & 39,4 \\
\hline 2001 & 20,0 & 59,1 & 62,6 & 13,4 & 35,1 \\
\hline 2002 & 25,6 & 61,7 & 65,1 & 15,2 & 34,9 \\
\hline 2003 & 23,8 & 61,5 & 65,0 & 13,6 & 33,8 \\
\hline 2004 & 25,5 & 56,9 & 59,8 & 13,9 & 27,6 \\
\hline 2005 & 25,2 & 54,1 & 56,8 & 15,4 & 31,4 \\
\hline 2006 & 22,9 & 47,4 & 49,7 & 14,6 & 28,7 \\
\hline 2007 & 20,8 & 42,5 & 44,6 & 14,8 & 30,0 \\
\hline 2008 & 22,6 & 43,0 & 45,2 & 14,9 & 13,7 \\
\hline 2009 & 19,0 & 43,4 & 46,0 & 15,9 & 12,0 \\
\hline 2010 & 19,0 & 46,0 & 48,8 & 21,3 & 11,4 \\
\hline 2011 & 16,9 & 43,4 & 46,3 & 16,8 & 9,7 \\
\hline 2012 & 20,2 & 46,5 & 49,5 & 16,2 & 10,1 \\
\hline
\end{tabular}




\begin{tabular}{l|c|c|c|c|c}
\hline & Москва & Россия & Россия без Москвы & Швеция & Эстония \\
\hline 2013 & 22,2 & 53,6 & 57,3 & 14,8 & 8,4 \\
2014 & 27,2 & 64,7 & 69,2 & 13,8 & 8,8 \\
2015 & 38,1 & 63,5 & 65,7 & 14,4 & 12,4 \\
2016 & 13,2 & 61,1 & 65,6 & - & - \\
2017 & 6,7 & 53,0 & 52,4 & - & -
\end{tabular}




\title{
DISTINCTIVE FEATURES AND COMPONENTS OF MORTALITY DECREASE IN MOSCOW IN 1989-2017
}

\author{
ELENA PAPANOVA, Vladimir SHKOLNIKOV, SERGEY TIMONIN
}

\begin{abstract}
Moscow is the region with the highest life expectancy in Russia. The country's largest city, it has high incomes, a special population structure and a high concentration of all resources, including in the healthcare sector, which is given special attention by the city authorities. In some periods, the changes in life expectancy in Moscow have been unique compared to most other regions of Russia. The difference in life expectancy between Moscow and Russia in the period from the mid-1990s to the mid-2000s was mainly due to lower mortality in middle age. Since the mid-2000s, the main contribution to the difference in life expectancy has been shifting to old age mortality. Given the overall rapid decline of mortality in Moscow since then, changes in the mortality rates and life expectancy of certain age groups seem implausible. The quality of population and mortality data has a significant impact on the accuracy of estimates of mortality indicators and requires special attention in the case of Moscow. In particular, the number of people at advanced ages in Moscow is likely to be overestimated, which affects mortality rates in this age group. Peculiarities of mortality by causes of death in Moscow generally correspond to the average Russian trends; however, in Moscow a more rapid decrease in mortality from neoplasms is observed, as well as more realistic age-specific death rates in older age groups.
\end{abstract}

Key words: mortality, life expectancy, old age, advanced age, working-age adults, quality of statistical data, causes of death.

Elena Papanova (epapanova@hse.ru), National Research University Higher School of Economics.

Vladimir Shkolnikov (vmshkolnikov@ hse.ru), NATIONAl RESEARCH University Higher SchoOl OF EcONOMICS, RuSSIA; MAX PLANCK INSTITUTE FOR DEMOGRAPHIC RESEARCH, GERMANY.

SERgey Timonin (stimonin@hse.ru), National Research University Higher School of Economics, Russia.

The Study has been funded by the Russian ACAdEmic Excellence ProJeCt «5-100».

DATE RECEIVED : OCTOBER 2018.

\section{REFERENCES}

Andreev E.M. (1982). The method of components in the analysis of length of life. Vestnik statistiki, 3, 42-47. (In Russ.)

Andreev E.M. (2012). On the accuracy of the results of Russian population censuses and the level of confidence in different sources of information. Voprosy statistiki [Statistical Issues], 11, 21-35. (In Russ.)

Andreev E.M. (2016). Ill-defined and unspecified causes of death in Russia. Demograficheskoe obozrenie [Demographic Review], 3(2), 103-142. doi:10.17323/demreview.v3i2.1755 (In Russ.)

Andreev E.M., Kvasha E.A., Khar'kova T.L. (2006). Special points on the mortality map. In A.G. Vishnevsky (Ed.), Naselenie Rossii 2003-2004. Odinnadtsatyy-dvenadtsatyy ezhegodnyy demograficheskiy doklad (pp. 298-305) [Russia's Population in 2003-2004. 1112 Annual Demographic Report]. Moscow: Nauka. (In Russ.)

Andreev E.M., Kvasha E.A., Khar'kova T.L. (2016). Mortality in Moscow and other megacities of the world: similarities and differences. Demograficheskoe obozrenie [Demographic Review], 3(3), 39-79. doi:10.17323/demreview.v3i3 (In Russ.) 
Andreev E.M., Shkolnikov V.M. (2018). The relationship between mortality and economic development in Russia and its regions. Demograficheskoe obozrenie [Demographic Review], 5(1), 6-24. doi:10.17323/demreview.v5i1.7707 (In Russ.)

Andreev E.M., Shkolnikov V.M., Begun A.Z. (2002). Algorithm for decomposition of differences between aggregate demographic measures and its application to life expectancies, healthy life expectancies, parity-progression ratios and total fertility rates. Demographic Research, 7(14), 499-522. doi:10.4054/DemRes.2002.7.14.

Arkhangel'skiy V.N., Ivanova A.E., Rybakovskiy L.L., Ryazantsev S.V. (2006).

Demograficheskaya situatsiya $v$ Moskve i tendentsii eye razvitiya [The demographic situation in Moscow and its development trends]. Moskva: TSentr sotsial'nogo prognozirovaniya. (In Russ.)

Center for Demographic Research. (2018). Russian Fertility and Mortality Database. Retrieved from http://www.demogr.nes.ru/index.php/ru/demogr_indicat/data (data downloaded on 05.07.2018).

Danilova I.A. (2015). The issue of quality of Russian cause-specific mortality statistics at old ages. Uspekhi gerontologii [Advances in Gerontology], 28(3), 409-414. (In Russ.)

Danilova I.A., Shkolnikov V.M., Jdanov D.A., Meslé F., Vallin J. (2016). Identifying potential differences in cause-of-death coding practices across Russian regions. Population Health Metrics, 14(8). doi:10.1186/s12963-016-0078-0

Eurostat (2018). Amenable and preventable deaths statistics. URL:

http://ec.europa.eu/eurostat/statistics-

explained/index.php/Amenable_and_preventable_deaths_statistics (data downloaded on 15.09.2018).

Gavrilova N.S., Semyonova V.G., Dubrovina E., Evdokushkina G.N., Ivanova A.E., Gavrilov L.A. (2008). Russian Mortality Crisis and the Quality of Vital Statistics. Population Research and Policy Review, 27, 551-574. doi:10.1007/s11113-008-9085-6

Gusmano M.K., Rodwin V.G., Wang C., Weisz D., Luo L., Hua F. (2015). Shanghai rising: health improvements as measured by avoidable mortality since 2000. International Journal of Health Policy and Management, 4(1), 7-12. http://doi.org/10.15171/ijhpm.2015.07

Gusmano M.K., Rodwin V.G., Weisz D., Ayoub R. (2016). Health Improvements in BRIC Cities: Moscow, São Paulo, and Shanghai, 2000-10. World Medical \& Health Policy, 8, 127138. doi:10.1002/wmh3.188

Ivanova A.E., Sabgayda T.P., Semenova V.G., Zaporozhenko V.G., Zemlyanova E.V., Nikitina S.YU. (2013). Factors distorting structure of death causes in working population in Russia. Sotsial'nyye aspekty zdorov'ya naseleniya [Social aspects of population health], 4(32). URL:http://vestnik.mednet.ru/content/view/49 1/30/lang,ru/ (In Russ.)

Jdanov D.A., Scholz R.D., Shkolnikov V.M. (2005). Official population statistics and the Human Mortality Database estimates of populations aged 80+ in Germany and nine other European countries. Demographic Research, 13(14), 335-362. doi:10.4054/DemRes.2005.13.14

Khar'kova T.L., Nikitina S.YU., Andreev E.M. (2017). Dependence of life expectancy on the education levels in Russia. Voprosy statistiki [Statistical Issues], 8, 61-68. (In Russ.)

Koster E.M., de Gelder R. , Di Nardo F., Williams G., Harrison A., van Buren L.P., Lyshol H., Patterson L., Birt C.A., Higgerson J., Achterberg P.W., Verma A., van Ameijden E.J.C. (2017). Health status in Europe: comparison of 24 urban areas to the corresponding 10 
countries (EURO-URHIS 2). European Journal of Public Health, 27(2), 62-67. doi:10.1093/eurpub/ckw188

Mkrtchyan N.V. (2012). Problemy ucheta naseleniya otdel'nykh vozrastnykh grupp v khode perepisi naseleniya $2010 \mathrm{~g} .:$ prichiny otkloneniy poluchennykh dannykh ot ozhidaemykh [Problems of registration of the population of certain age groups during the 2010 census: reasons for deviations of the data from the expected] / In M.B. Denisenko (Ed.), Demograficheskie aspekty sotsial'no-ehkonomicheskogo razvitiya [Demographic aspects of social and economic development], Vyp. 22 (pp. 197-214.). Moscow: MAKS Press. (In Russ.)

Nemtsov A.V. (2003). Alkogol'nyy uron regionov Rossii [Alcohol-Induced Harm in the Regions of Russia]. Moscow: NALEX. (In Russ.)

Papanova E.K., Shkolnikov V.M., Andreev E.M., Timonin S.A. (2017). High life expectancy of muscovites at old ages: reality or statistical artifact? Uspekhi gerontologii [Advances in Gerontology], 30(6), 826-835. (In Russ.)

Preston S., Elo I. (2014). Anatomy of a Municipal Triumph: New York City's Upsurge in Life Expectancy. Population and Development Review, 40(1), 1-29. doi:10.1111/j.17284457.2014.00648.x

Pridemore W.A. (2003). Measuring homicide in Russia: a comparison of estimates from the crime and vital statistics reporting system. Social Science \& Medicine, 57(8), 1343-1354. doi:10.1016/S0277-9536 (02) 00509-9

Revich B.A. (2011). Heat-wave, air quality and mortality in European Russia in summer 2010: preliminary assessment. Ehkologiya cheloveka [Human Ecology], 7, 3-9. (In Russ.)

Roshchin D.O., Sabgayda T.P., Evdokushkina G.N. (2012). The problem of diabetes mellitus recording while diagnostics of death causes. Sotsial'nye aspekty zdorov'ya naseleniya [Social aspects of population health], 5(27). URL:

http://vestnik.mednet.ru/content/view/430/30/lang,ru/ (In Russ.)

Semenova V.G., Antonova O.I. (2007). The validility of the mortality statistics (on example of mortality from injury and poisoning in Moscow). Sotsial'nyye aspekty zdorov'ya naseleniya [Social aspects of population health], 2. URL: http://vestnik.mednet.ru/content/view/28/30/ (In Russ.)

Shaposhnikov D., Revich B., Bellander T., Bedada G.B., Bottai M., Kharkova T., Kvasha E., Lezina E., Lind T., Semutnikova E., Pershagen G. (2014). Mortality Related to Interactions Between Heat Wave and Wildfire Air Pollu-tion During the Summer of 2010 in Moscow. Epidemiology, 3(25), 359-364. doi:10.1097/EDE.0000000000000090

Shkolnikov V.M., Andreev E.M., Jasilionis D., Leinsalu M., Antonova O.I., McKee M. (2006). The Changing Relation between Education and Life Expectancy in Central and Eastern Europe in the 1990s. Journal of Epidemiology and Community Health, 60(10), 875-881.

Shkolnikov V.M., Andreev E.M., McKee M., Leon D.A. (2013). Components and possible determinants of the decrease in Russian mortality in 2004-2010. Demographic Research, 28(32), 917-950. doi:10.4054/DemRes.2013.28.32

Shkolnikov V.M., Cornia G.A. (2000). Population crisis and rising mortality in transitional Russia. In G.A. Cornia, R. Paniccià (Eds.), The mortality crisis in transitional economies (pp. 253-279). Oxford: Oxford University Press.

Shkolnikov V.M., Cornia G.A., Leon D.A., Meslé F. (1998a). Causes of the Russian Mortality Crisis: Evidence and Interpretations. World Development, 26(6), 1995-2011. 
Shkolnikov V.M., Leon D.A., Adamets S., Andreev E.M., Deev A. (1998b). Educational Level and Adult Mortality in Russia: An Analysis of Routine Data 1979 to 1994. Social Science and Medicine, 47(3), 357-369.

Shkolnikov V.M., McKee M., Chervyakov V.V., Kiryanov N.A. (2002). Is the link between alcohol and cardiovascular death among young Russian men attributable to misclassification of acute alcohol intoxication? Evidence from the city of Izhevsk. Journal of Epidemiology and Community Health, 56(3), 171-174. doi:10.1136/jech.56.3.171

Shkolnikov V.M., McKee M., Vallin J., Aksel E., Leon D., Chenet L., Meslé F. (1999). Cancer mortality in Russia and Ukraine: validity, competing risks, and cohort effects. International Journal of Epidemiology, 28, 19-29.

Shkolnikov V.M., Meslé F., Vallin J. (1996). Health Crisis in Russia I. Recent Trends in Life Expectancy and Causes of Death from 1970 to 1993. Population: An English Selection, 8, $123-154$.

Sidorenkov O., Nilssen O., Nieboer E., Kleschinov N., Grjibovski A.M. (2011). Premature cardiovascular mortality and alcohol consumption before death in Arkhangelsk, Russia: an analysis of a consecutive series of forensic autopsies. International Journal of Epidemiology, 40(6), 1519-1529. doi:0.1093/ije/dyr145

Thatcher A.R., Kannisto V., Andreev K.F. (2002). The survivor ratio method for estimating numbers at high ages. Demographic Research, 6(1), 1-16. doi:10.4054/DemRes.2002.6.1

Timonin S.A., Danilova I.A., Andreev E.M., Shkolnikov V.M. (2017). Recent mortality trend reversal in Russia: are regions following the same tempo? European Journal of Population, 33(5), 733-763. doi:10.1007/s10680-017-9451-3

Todd M.A., Shkolnikov V.M., Goldman N. (2016). Why are well-educated Muscovites more likely to survive? Understanding the biological pathways. Social Science \& Medicine, 157, 138-147. http://doi.org/10.1016/j.socscimed.2016.02.041 V.M.

University of California, Berkeley, Max Planck Institute for Demographic Research (MPIDR). (2018). Human Mortality Database. Retrieved from http://www.mortality.org. (data downloaded on 20.06.2018)

Vallin J., Andreev E.M., Meslé F., Shkolnikov (2005). Geographical diversity of cause-of-death patterns and trends in Russia. Demographic Research, 12(13), 323-380.

Vasin S.A. (2015). Mortality from undetermined causes of death in Russia and in a selected set of countries. Demograficheskoye obozreniye [Demographic Review], 2(1), 89-124. doi:/10.17323/demreview.v2i1.1790 (In Russ.)

Vishnevsky A.G., Andreev E.M., Timonin S.A. (2016). Mortality from cardiovascular diseases and life expectancy in Russia. Demograficheskoe obozrenie [Demographic Review], 3(1), 634. doi:10.17323/demreview.v3i1.1761 (In Russ.)

WHO Regional Office for Europe. (2018). European Health for All database (HFA-DB). Retrieved from https://gateway.euro.who.int/en/datasets/european-health-for-all-database/ (data downloaded on 15.09.2018).

WHO. (2018). World Health Organization Mortality Database. Retrieved from http://www.who.int/healthinfo/mortality_data/en/ (data downloaded 10.06.2018).

Zaridze D., Maximovitch D., Lazarev A., Igitov V., Boroda A., Boreham J. et al. (2009). Alcohol poisoning is a main determinant of recent mortality trends in Russia : evidence from a detailed analysis of mortality statistics and autopsies. International Journal of Epidemiology, 38(1), 143-153. doi:10.1093/ije/dyn160 
Zemlyanova E., Lopakov K., Ivanova A. (2017). Regional mortality differences in big Russian cities. European Journal of Public Health, 27(3). doi:10.1093/eurpub/ckx186.007 